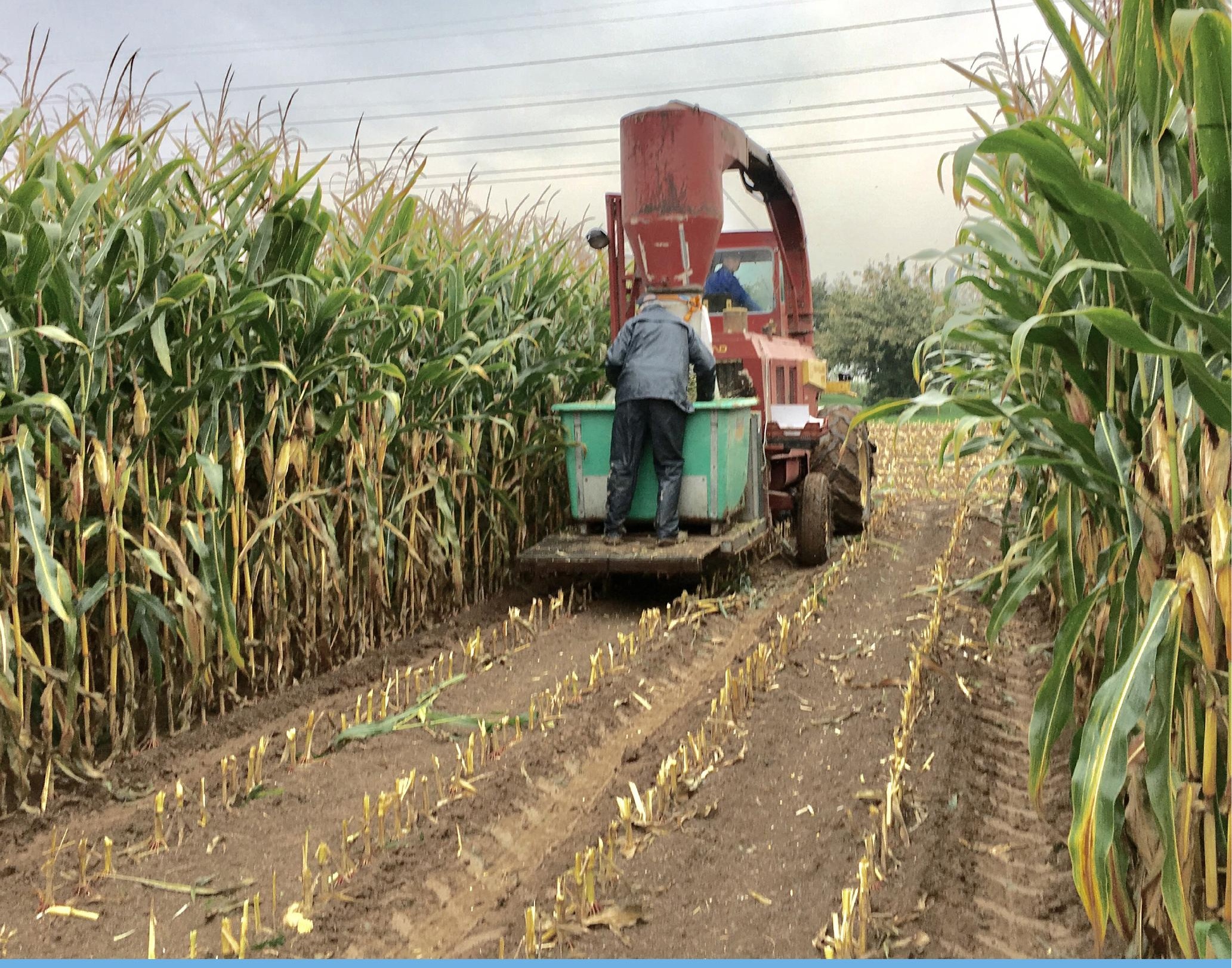

Naar een nieuw kalibemestingsadvies voor snijmaïs

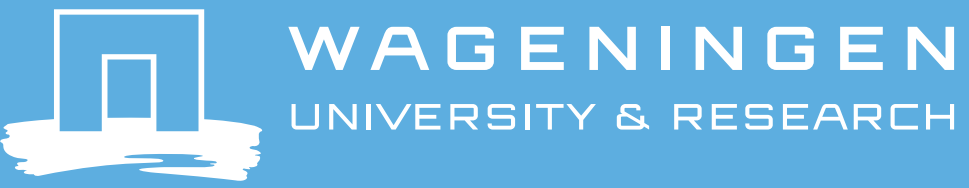





\section{Naar een nieuw kalibemestingsadvies voor snijmaïs}

G. Holshof ${ }^{1}$, D.W. Bussink ${ }^{2}$, J.C. van Middelkoop ${ }^{1}$, G. Doppenberg ${ }^{2} \&$ H. van Schooten ${ }^{1}$

1 Wageningen Livestock Research

2 Nutriënten Management Instituut NMI

Dit onderzoek is uitgevoerd door Wageningen Livestock Research en Nutriënten Management Instituut, in opdracht van en gefinancierd door ZuivelNL

Wageningen Livestock Research

Wageningen, juli 2019 
G. Holshof, D.W. Bussink, J.C. van Middelkoop, G. Doppenberg \& H. van Schooten, 2019. Naar een nieuw kalibemestingsadvies voor snijmaïs. Wageningen Livestock Research, Rapport 1189.

\section{Samenvatting}

Een goede kali $(K)$ voorziening bij de teelt van snijmaïs is van belang voor een goede opbrengst en een efficiënte benutting van stikstof en fosfaat. In een veldonderzoek in 2015, 2016 en 2017 is de respons van snijmaïs vastgelegd op K-bemesting met kunstmest en rundveedrijfmest, zowel volvelds als in de rij toegediend bij verschillende K-voorraden in de bodem. De respons van de drogestofopbrengst op $\mathrm{K}$ uit bodem en bemesting was beperkt; de respons van K-gehalte en drogestofgehalte was duidelijk aanwezig. Er was geen verschil in respons tussen dierlijke en minerale bemesting en tussen volveldse en rijenbemesting. Het $\mathrm{K}$-bemestingsadvies is gebaseerd op gewasonttrekking met correctie naar beneden bij $\mathrm{K}-\mathrm{CaCl}_{2}>60$.

\section{Summary}

A sufficient potassium (K) supply for whole crop silage maize is necessary for a good yield and nutrient efficiency for nitrogen and phosphorus. In a field trial in 2015, 2016 and 2017 the response of silage maize to $\mathrm{K}$ fertilization was limited, both for mineral $\mathrm{K}$ and $\mathrm{K}$ from cattle slurry, and surface spread and band application, at different levels of soil $\mathrm{K}$ supply; the response of $\mathrm{K}$ content and dry matter content was clearly present. No difference between mineral and organic fertilizer or surface spread and band application was found. The $\mathrm{K}$-fertilization recommendation is based on $\mathrm{K}$ withdrawal by the crop with a negative correction when $\mathrm{K}-\mathrm{CaCl}_{2}>60$.

Dit rapport is gratis te downloaden op https://doi.org/10.18174/498155 of op www.wur.nl/livestock-research (onder Wageningen Livestock Research publicaties).

\section{(C) 2019 Wageningen Livestock Research}

Postbus 338, 6700 AH Wageningen, T 03174839 53, E info.livestockresearch@wur.nl, www.wur.nl/livestock-research. Wageningen Livestock Research is onderdeel van Wageningen University \& Research.

Wageningen Livestock Research aanvaardt geen aansprakelijkheid voor eventuele schade voortvloeiend uit het gebruik van de resultaten van dit onderzoek of de toepassing van de adviezen.

Alle rechten voorbehouden. Niets uit deze uitgave mag worden vermenigvuldigd en/of openbaar gemaakt worden door middel van druk, fotokopie, microfilm of op welke wijze dan ook zonder voorafgaande toestemming van de uitgever of auteur.

Wageningen Livestock Research is NEN-EN-ISO 9001:2015 gecertificeerd. Op al onze onderzoeksopdrachten zijn de Algemene Voorwaarden van de Animal Sciences Group van toepassing. Deze zijn gedeponeerd bij de Arrondissementsrechtbank Zwolle. 


\section{Inhoud}

Woord vooraf $\quad 5$

$\begin{array}{ll}\text { Samenvatting } & 7\end{array}$

$1 \quad$ Inleiding

11

1.1 Vraagstelling $\quad 12$

2

$\begin{array}{ll}\text { Materiaal en methode } & 13\end{array}$

2.1 Detailproeven 13

2.2 Miniproeven 14

$\begin{array}{lll}2.3 & \text { Statistische analyse } & 15\end{array}$

2.3.1 Detailproeven $\quad 15$

2.3.2 Miniproeven en detailproeven integraal 16

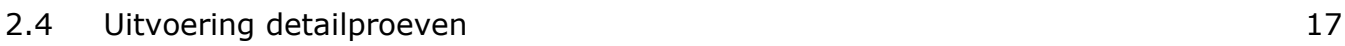

$\begin{array}{ll}2.4 .1 & \text { Locaties detailproeven } \\ 2.4 .2 & 17\end{array}$

2.4.2 Bodemanalyses en bemesting detailproeven 17

2.4.3 Uitvoering 18

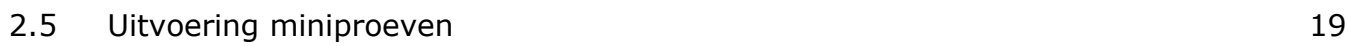

$\begin{array}{lll}2.6 & \text { Weersomstandigheden } & 20\end{array}$

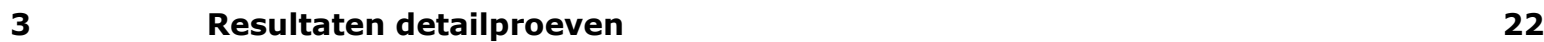

$3.1 \quad$ Basisresultaten drogestofopbrengsten $\quad 22$

$\begin{array}{lll}3.2 & \text { Basisresultaten K-opbrengsten } & 23\end{array}$

$\begin{array}{lll}3.3 & \text { Statistische analyse van de opbrengsten detailproeven } & 25\end{array}$

$\begin{array}{ll}\text { Kwantificering effecten } & 26\end{array}$

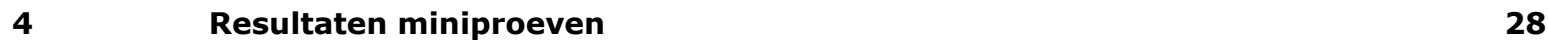

4.1 Grond- en mestanalyses $\quad 28$

4.2 Basisresultaten opbrengst, K-gehalte en -opname 30

4.3 Basisresultaten N- en P-gehalte en -opname 32

$5 \quad$ Modelanalyse detail- en miniproeven $\quad 34$

5.1 Statistische analyse mini- en detailproeven samen $\quad 34$

$\begin{array}{lll}5.1 .1 & \text { Algemeen } & 34\end{array}$

5.1.2 Drogestofopbrengst: $\mathrm{CEC}$ en $\mathrm{K}-\mathrm{CaCl}_{2} \quad 35$

$5.1 .3 \mathrm{~K}(2 \mathrm{O})$-opbrengst: $\mathrm{CEC}$ en $\mathrm{K}-\mathrm{CaCl}_{2}$

$\begin{array}{ll}5.1 .4 & \text { Drogestofopbrengst: } \mathrm{K}-\mathrm{HCl}\end{array}$

$\begin{array}{llr}6 & \text { Discussie } & 41\end{array}$

$\begin{array}{lll}6.1 & \text { Kritisch K-gehalte en gewasopname } & 41\end{array}$

6.2 Mechanismen hoe kalium droogtetolerantie maïs beïnvloedt 43

6.3 Naar een K-bemestingsadvies $\quad 45$

6.4 Kali-bemesting met dierlijke mest en rijenbemesting en magnesium uit bodem en $\begin{array}{ll}\text { dierlijke mest } & 48\end{array}$

$\begin{array}{lll}6.5 & \text { Advies en dierlijke bemesting } & 49\end{array}$

$\begin{array}{llr}7 & \text { Conclusies en bemestingsadvies } & 50\end{array}$

$\begin{array}{ll}\text { Literatuur } & \mathbf{5 2}\end{array}$

$\begin{array}{lll}\text { Bijlage } 1 & \text { Proefveldschema's } & 53\end{array}$ 
Bijlage 2 Weersomstandigheden detailproeven (details)

Bijlage 3 Resultaten drogestofopbrengst en K-gehalte detailproeven 62

$\begin{array}{lll}\text { Bijlage } 4 & \text { Statistische analyse detailproeven } & 64\end{array}$

Bijlage 5 Effectiviteit van K uit drijfmest ten opzichte van K uit kunstmest 75 


\section{Woord vooraf}

In 2015, 2016 en 2017 hebben Wageningen Livestock Research (WLR) en Nutriënten Management Instituut (NMI) gezamenlijk veldonderzoek uitgevoerd naar het effect van kali (K) bemesting op snijmaïs. In een voorstudie bleek dat het K-bemestingsadvies voor snijmaïs aan vernieuwing toe was (http://edepot.wur.nl/187039). Op basis van deze voorstudie is het veldonderzoek ontworpen en uitgevoerd. De proeven zijn uitgevoerd door de proefbedrijven Unifarm (Wageningen), Vredepeel (Vredepeel) en Kooijenburg (Marwijksoord) .

Met de resultaten hebben WLR en NMI een nieuw K-bemestingsadvies opgesteld. Dit was in nauwe samenwerking met de Commissie Bemesting Grasland en Voedergewassen (CBGV). De CBGV is een initiatief van LTO en wordt door ZuivelNL gefinancierd. De resultaten van de veldproeven en het daaruit voortkomende bemestingsadvies zijn in plenaire vergaderingen van de CBGV gepresenteerd en besproken.

Het K-bemestingsadvies is in voorjaar 2019 geïntroduceerd tijden de jaarlijkse thema-middag van de CBGV en gepubliceerd in de Adviesbasis Bemesting voor Grasland en Voedergewassen (www.bemestingsadvies.nl).

Het project is volledig gefinancierd door ZuivelNL. 


\title{
Samenvatting
}

\author{
Aanleiding \\ Kalium $(K)$ is belangrijk voor de opbrengst van snijmaïs. Voor een goede opbrengst en benutting van \\ de gegeven stikstof en fosfaat, waarvoor in Nederland gebruiksnormen gelden, is het belangrijk dat $\mathrm{K}$ \\ niet beperkend is. De fosfaatgebruiksnormen beperken de hoeveelheid mest die per ha kan worden \\ toegediend. Met $33 \mathrm{~m}^{3}$ rundveedrijfmest wordt ca. $50 \mathrm{~kg}$ fosfaat (de gebruiksnorm bij bodemtoestand \\ hoog) gegeven en circa $180 \mathrm{~kg} \mathrm{~K} 2 \mathrm{O}$. Dat is lager dan het huidige maximale bemestingsadvies van 300 \\ $\mathrm{kg} \mathrm{K}{ }_{2} \mathrm{O} / \mathrm{ha}$ bij een lage toestand. In deze situaties zou aanvulling met kunstmest nodig zijn. Als door \\ onderzoek blijkt dat het maximale K-bemestingsadvies kan dalen verbetert dit rendement van de \\ melkveehouderij sector omdat dan minder aanvulling met kunstmest nodig is. \\ Eerder is een voorstudie uitgevoerd naar de achtergronden en doelmatigheid van het huidige $\mathrm{K}$ - \\ bemestingsadvies voor maïs. De voorstudie gaf aanleiding om veldonderzoek uit te voeren om een \\ actueel kali-bemestingsadvies voor de teelt van snijmaïs vast te stellen. \\ In dit veldonderzoek zijn de volgende vragen beantwoord: \\ 1. Wat is de relatie tussen drogestofopbrengst en het kaliumgehalte in het gewas en de \\ bodemanalyse en gegeven K-bemesting? \\ 2. Wat is het effect van bodemparameters als $\mathrm{pH}, \mathrm{Mg}$-gehalte, CEC en CEC-bezetting? \\ 3. Wat is de efficiëntie van $K$, toegediend als rijenbemesting ten opzichte van volvelds toegediend?
}

Om deze vragen te beantwoorden is gedurende twee jaar onderzoek uitgevoerd via detailonderzoek op 3 proeflocaties en miniproeven op 20 praktijklocaties. Op basis van de resultaten is een $\mathrm{K}$ bemestingsadvies voor snijmaïs afgeleid.

\section{Opzet detailproeven}

In 2015, 2016 en 2017 zijn op drie locaties proefvelden met het gewas snijmaïs aangelegd: twee op zandgrond: Marwijksoord (MW) en Vredepeel (VP), en één op kleigrond: Wageningen (Wg). De locaties waren geselecteerd op onder andere een relatief lage $\mathrm{K}$-toestand $\left(\mathrm{K}-\mathrm{CaCl}_{2} \leq 50\right)$. Het plan was om in 2015 en 2016 de proeven uit te voeren maar in 2016 hebben de weersomstandigheden (wateroverlast) de proeven op de locaties VP en Wg verstoord. In 2017 is op deze locaties de proef opnieuw uitgevoerd.

In 2015 werden behandelingsfactoren met rundveedrijfmest ( $\mathrm{rdm})$ en kunstmest $(\mathrm{km})$ aangelegd:

1. Geen $\mathrm{rdm}+\mathrm{K}_{2} \mathrm{O} \mathrm{km}$ volvelds: $0,40,80,160$ en $320 \mathrm{~kg} / \mathrm{ha}$

2. Geen $\mathrm{rdm}+\mathrm{K}_{2} \mathrm{O} \mathrm{km}$ rijenbemesting: 40,80 en $160 \mathrm{~kg} / \mathrm{ha}$

3. $\mathrm{Rdm}$ volvelds $\left(20 \mathrm{~m}^{3} \sim 110 \mathrm{~kg} \mathrm{~K}{ }_{2} \mathrm{O} / \mathrm{ha}\right)+\mathrm{K}_{2} \mathrm{O} \mathrm{km}$ volvelds: $0,40,80$ en $160 \mathrm{~kg} / \mathrm{ha}$

4. Rdm volvelds $\left(20 \mathrm{~m}^{3} \sim 110 \mathrm{~kg} \mathrm{~K}{ }_{2} \mathrm{O} / \mathrm{ha}\right)+\mathrm{K}_{2} \mathrm{O} \mathrm{km}$ rijenbemesting: 40 , 80 en $160 \mathrm{~kg} / \mathrm{ha}$

5. Rdm rijenbemesting $\left(20 \mathrm{~m}^{3} \sim 110 \mathrm{~kg} \mathrm{~K}{ }_{2} \mathrm{O} / \mathrm{ha}\right)+\mathrm{K}_{2} \mathrm{O} \mathrm{km}$ volvelds: 0,40 en $80 \mathrm{~kg} / \mathrm{ha}$

6. Rdm rijenbemesting $\left(20 \mathrm{~m}^{3} \sim 110 \mathrm{~kg} \mathrm{~K}{ }_{2} \mathrm{O} / \mathrm{ha}\right)+\mathrm{K}_{2} \mathrm{O} \mathrm{km}$ rijenbemesting: 40 en $80 \mathrm{~kg} / \mathrm{ha}$

De N-bemesting op de objecten was $200 \mathrm{~kg} \mathrm{~N} / \mathrm{ha}$, inclusief werkzame N-bemesting uit drijfmest. Na één jaar bleek dat rijenbemesting met kali van kunstmest èn rdm geen voordelen biedt. Daarom zijn behandelingen met kunstmestrijenbemesting vervangen door kalitrappen bij een lagere $\mathrm{N}$-gift $(100 \mathrm{~kg} / \mathrm{ha})$.

\section{Opzet miniproeven}

Op basis van grondonderzoek zijn op 20 bedrijven (12 op zand en 8 op klei) twee percelen geselecteerd met een duidelijk verschil in K-toestand. In 2016 is de proef op een ander deel van het perceel aangelegd dan in 2015. Als er bedrijven uitvielen dan zijn die vervangen door percelen op andere bedrijven. Op de 20 praktijkbedrijven zijn 6 behandelingen aangelegd:

- Geen mest, 0, 40, 80 en $160 \mathrm{~kg} \mathrm{~K}{ }_{2} \mathrm{O} /$ ha uit kunstmest

- $\operatorname{Rdm}\left(40 \mathrm{~m}^{3} \sim 220 \mathrm{~kg} \mathrm{~K}{ }_{2} \mathrm{O} / \mathrm{ha}\right), 0$ en $80 \mathrm{~kg} \mathrm{~K}{ }_{2} \mathrm{O} /$ ha uit kunstmest

In totaal waren er 480 veldjes over beide jaren. 


\section{Resultaten en statistische analyse detailproeven}

- $\quad$ K-bemesting had geen effect op de drogestofopbrengst. K-bemesting had wel een positief effect op de vers-opbrengst, het K-gehalte en de K-opbrengst en een negatief effect op het drogestofgehalte.

- In het eerste proefjaar was er op alle drie de locaties een negatief effect van K-bemesting op zetmeelgehalte, in het tweede proefjaar was er geen effect.

- Het toedienen van volvelds drijfmest had, net als kunstmest, vrijwel geen effect op drogestofopbrengst. Alleen op klei in 2015 was er een negatief effect van ca. $700 \mathrm{~kg}$ ds/ha. Er was een positief effect op de vers-opbrengst, het K-gehalte en de K-opbrengst en een negatief effect op drogestofgehalte.

- $\quad$ Drijfmest in de rij toedienen had een gelijk effect voor K-gehalte en -opbrengst als volvelds drijfmest toedienen.

- Het verlagen van het stikstofniveau van 200 naar $100 \mathrm{~kg} \mathrm{~N} / \mathrm{ha}$ (in 2016 en 2017 uitgevoerd) had op de twee locaties een negatief effect op drogestofopbrengst van ca. $700 \mathrm{~kg} \mathrm{ds} / \mathrm{ha}$ en op ruw eiwitgehalte van 2 tot $3 \mathrm{~g}$ re/kg ds.

- Het effect van rijenbemesting met K-kunstmest verschilde alleen op locatie Vredepeel in 2017 van het effect van volvelds toedienen: de effecten van de K-bemesting met kunstmest op K-gehalte, opbrengst, vers-opbrengst en drogestofgehalte waren groter wanneer rijenbemesting werd toegepast in plaats van volvelds.

- $\quad$ Er was geen verschil in de grootte van de respons in $\mathrm{K}$-gehalte en $\mathrm{K}$-opbrengst tussen rijenbemesting en volvelds bemesting met drijfmest.

- De respons van $\mathrm{K}$-gehalte en $\mathrm{K}$-opbrengst op de $\mathrm{K}$ uit drijfmest was altijd gelijk of hoger dan de respons op $\mathrm{K}$ uit kunstmest. De K-werkingscoëfficiënt van drijfmest was steeds minimaal $100 \%$.

\section{Resultaten mini-proeven}

- $\quad$ Er was een ruime variatie in bodemkengetallen. Met betrekking tot het $\mathrm{K}$-gehalte varieerde $\mathrm{K}$ in $\mathrm{CaCl} 2$-extractie van meer dan 9 tot $400 \mathrm{mg} \mathrm{kg-1.}$

- De gemiddelde opbrengst bevond zich op een goed niveau met een opbrengst van bijna 19 ton ds ha-1. Er was een groot verschil in opbrengstniveau tussen locaties (8-25 ton ds ha-1).

- Het K-gehalte bedroeg gemiddeld ruim 10,5 g K kg-1 ds, waarbij zo'n 15\% van de gevallen er minder dan $8 \mathrm{~g} \mathrm{~K} \mathrm{kg-1}$ ds aanwezig was. Het verschil tussen een lage en hoge K-bemesting was ongeveer $1 \mathrm{~g} \mathrm{~kg}-1 \mathrm{ds}$.

- De opbrengstniveaus waren in beide jaren vergelijkbaar. De K- en K2O-opbrengsten bedroegen gemiddeld respectievelijk 210 en 253 kg ha-1 in 2015 en 187 en 226 kg ha-1 in 2016 . Het verschil tussen geen en $160 \mathrm{~K} 2 \mathrm{O}$-bemesting was beperkt en bedroeg ongeveer $20 \mathrm{~kg} \mathrm{~K} 2 \mathrm{O}$ ha-1 in beide jaren.

- $\quad$ De gekozen percelen verschilden sterk in $\mathrm{K}-\mathrm{CaCl} 2$ waarden. Toch lijkt er geen sterk verband te zijn tussen deze waarde en de drogestofopbrengst. Zelfs bij heel lage waarden kon met bemesting een vergelijkbare opbrengst worden gerealiseerd als bij een hoge $\mathrm{K}-\mathrm{CaCl} 2$ waarde.

- $\quad$ Het K-gehalte hing sterk samen met het drogestofgehalte van de mais. Hoe hoger het K-gehalte des te lager was het drogestofgehalte.

\section{Statistische analyse detail- en miniproeven samen}

Nagegaan is welke bodem- en bemestingsfactoren van invloed zijn op de drogestofopbrengst, de Kopbrengst en het $\mathrm{K}$-gehalte. Dit is gedaan in een statistische analyse voor de miniproeven en de detailproeven samen. De bevindingen waren:

\section{Drogestofopbrengst:}

- $\quad$ K, CEC, de bezetting van het adsorptiecomplex en de (werkzame) K-bemesting waren van invloed op de drogestofopbrengst. In het traject van 20 tot $60 \mathrm{~K}-\mathrm{CaCl} 2$ was er een positief effect van bemesting dat daalde naar 0 naarmate $\mathrm{K}-\mathrm{CaCl} 2$ steeg naar 60. Daarboven was er geen effect meer van K-bemesting op de opbrengst.

- De maximale opbrengst was te verkrijgen door een $\mathrm{K}$-bemestingshoeveelheid die veel kleiner was dan de gewasonttrekking (40-80 kg K2O ha-1). Waarschijnlijk laat zich dat verklaren door Knalevering uit diepere bodemlagen en dat het gewas steeds dieper wortelt bij verdere groei.

\section{K-gehalte:}

- De kaligift, $\mathrm{K}-\mathrm{CaCl} 2, \mathrm{CEC}$, magnesiumbemesting en -toestand en hun interacties waren van invloed op het K-gehalte in mais. De relaties zijn complex en zijn niet nader geduid. 
- De experimenten gaven een kritisch K-gehalte van ongeveer 8,0-8,5 g K kg-1. Deze waarde stemt goed overeen met waarden in literatuur. Er wordt in de oudere literatuur echter ook een hogere waarde als een indicator voor een adequate K-voorziening voorgesteld van $13 \mathrm{~g} \mathrm{kg-1} \mathrm{ds.} \mathrm{Eén} \mathrm{van}$ de belangrijke effecten die aan een goede kalivoorziening worden toegeschreven is dat het gewas beter bestand is tegen droogte waardoor het gewas beter kan blijven produceren. Er zijn echter weinig aanwijzingen dat daarvoor echt hoge bemestingen nodig zijn om mais beter resistent te maken tegen droogte. Bovendien bleek uit proeven in literatuur dat kalium het effect van droogtestress niet opheft.

\section{Drogestofpercentage:}

- Opvallend was dat de hoogste drogestofpercentages bij de oogst samenvielen met de laagste Kgehalten in de drogestof en dat deze ook gepaard leken te gaan met de hoogste drogestofopbrengsten. Het lijkt erop dat hoge K-gehalten in de drogestof de afrijping van de mais vertragen. Het gewas blijft langer groen. Voedertechnisch leek er geen voordeel te zijn van langer groen blijven cq. van een lager drogestofgehalte (door hogere K-bemesting) zo blijkt uit de analyse van de voederwaarde (VEM en zetmeel) in de detailproef.

\section{$K$ uit kunstmest en drijfmest:}

- Voor het effect van K-bemesting op de opbrengst behoeft geen onderscheid gemaakt te worden tussen kali uit kunstmest en werkzame $\mathrm{K}$ uit rundveedrijfmest.

- Op de objecten met drijfmest was, gemiddeld over alle data, de opbrengst 1 ton lager dan op de objecten zonder drijfmest.

\section{Invloed CEC:}

- $\quad B i j$ een hoge CEC was er weinig effect van bemesting op het $\mathrm{K}$-gehalte. Bij een hoge CEC was een veel hogere $\mathrm{K}-\mathrm{CaCl}_{2}$ nodig om eenzelfde $\mathrm{K}$-gehalte en $\mathrm{K}$-opbrengst te realiseren als bij een lage CEC. Ofwel: bij een hoge CEC heeft het gewas een hogere bodemvoorraad nodig en is de $\mathrm{K}$ uit bemesting minder effectief dan bij een lage CEC.

\section{K-HCl:}

- Toevoegen van de $\mathrm{K}-\mathrm{HCl}$ analyse, de bodemanalyse waar het $\mathrm{K}$-bemestingsadvies tot nu toe op gebaseerd was, gaf geen betere verklaring van de gewasrespons. Het gebruik van $\mathrm{K}-\mathrm{HCl}$ in plaats van $\mathrm{K}-\mathrm{CaCl}_{2}, \mathrm{CEC}$ en de andere verklarende factoren gaf een slechtere verklaring van de gewasrespons en is dus minder geschikt voor het K-bemestingsadvies.

\section{Lange termijn:}

- $\quad$ Op de lange termijn gezien kan een bemesting van 40-80 $\mathrm{kg} \mathrm{K}_{2} \mathrm{O}$ ha-1 niet toereikend zijn omdat er uitmijning van kali plaatsvindt. Bovendien kan kali op de lichtere gronden gemakkelijk uitspoelen. Daar tegenover staat dat door capillaire opstijging een deel van deze kali alsnog beschikbaar is voor het gewas, vooral in het tweede deel van het groeiseizoen.

\section{K-bemestingsadvies voor snijmaïs}

Een K-bemestingsadvies mede gebaseerd op onttrekking is gewenst om te voorkomen dat gronden op termijn worden uitgemijnd bij lage kaligiften. Daarbij kan uitgegaan worden van een kritisch K-gehalte $8,0-8,5 \mathrm{mg} \mathrm{kg}^{-1}$. Hoewel kali een rol speelt met betrekking tot het verminderen van droogtestress zijn er geen aanwijzingen dat hiervoor duidelijk hogere gehalten dan $8,0-8,5 \mathrm{mg} \mathrm{kg}^{-1}$ nodig zijn in de drogestof. Op basis van de literatuur en de resultaten lijkt een hoge kaligift eerder nadelig dan voordelig te werken op de opbrengst.

Er zijn 3 mogelijkheden voor een bemestingsadvies:

1. Bemesten op onttrekking.

2. Bemesten op onttrekking en rekening houdend met de bodemtoestand via $\mathrm{K}-\mathrm{CaCl}_{2}$. Bij waarden boven een zekere streeftoestand wordt er gekort. Bij waarden onder de streeftoestand wordt er extra gegeven. Op termijn wordt zo de streeftoestand gerealiseerd.

3. Bemesten op onttrekking en rekening houdend met de bodemtoestand via $\mathrm{K}-\mathrm{CaCl}_{2}$ en de $\mathrm{CEC}$.

Ad 1). Bij alleen bemesten op onttrekking kan grondonderzoek achterwege blijven. Tegelijk betekent het dat percelen met een hoge toestand met kali bemest worden terwijl ze dat eigenlijk niet nodig hebben. Op basis van de voorhanden informatie lijkt dat eerder nadelig dan voordelig uit te pakken voor de opbrengst. 
Ad 2) In de proeven werd tot een $\mathrm{K}-\mathrm{CaCl}_{2}$ van $60 \mathrm{mg} \mathrm{kg}^{-1}$ een opbrengstrespons van kali-bemesting gemeten. Uitgangspunt voor het bemestingsadvies op onttrekking kan zijn een kritisch $\mathrm{K}$-gehalte 8,3 $\mathrm{mg} \mathrm{kg}^{-1}$ ofwel $10 \mathrm{mg} \mathrm{K}_{2} \mathrm{O} \mathrm{kg}{ }^{-1}$ met een streeftoestand voor $\mathrm{K}-\mathrm{CaCl}_{2}$ van $60 \mathrm{mg} \mathrm{kg}^{-1}$. Dit kan leiden tot de volgende formules:

$\mathrm{K}_{2} \mathrm{O}-$ gift $=10 *$ Dsopbrengst (ton per ha) $-\mathrm{a} *\left(\mathrm{~K}-\mathrm{CaCl}_{2}-60\right)$ )

Of tot:

- $\quad$ bij $\mathrm{K}-\mathrm{CaCl}_{2}$ van $<60 \mathrm{mg} \mathrm{kg}{ }^{-1}: \mathrm{K}_{2} \mathrm{O}$-gift= $10 *$ Dsopbrengst (ton per ha)

- bij K-CaCl 2 van $>60 \mathrm{mg} \mathrm{kg}{ }^{-1}: \mathrm{K}_{2} \mathrm{O}$-gift= $10 *$ Dsopbrengst (ton per ha) $-\mathrm{a} *\left(\mathrm{~K}-\mathrm{CaCl}_{2}-60\right)$ ) (6b)

waarbij a 2 of 3 is.

Ad 3) Uitgangspunt was om een advies te ontwikkelen op basis van $\mathrm{K}-\mathrm{CaCl}_{2}$ en $\mathrm{CEC}$. Bij een hoge $\mathrm{CEC}$ wordt $\mathrm{K}$ sterker gebufferd dan bij een lage $\mathrm{CEC}$. Bij een hoge $\mathrm{CEC}$ en een lage $\mathrm{K}-\mathrm{CaCl}_{2}$ zou dan mogelijk meer $\mathrm{K}$ nodig zijn om eenzelfde opbrengstrespons te generen.

Uit onze proeven is dat niet gebleken. Wel was er een effect op K-opbrengst en K-gehalte. Zo was het $\mathrm{K}$-gehalte bij een CEC van 200 duidelijk lager dan bij een CEC van 40 bij eenzelfde $\mathrm{K}-\mathrm{CaCl}_{2}$. Tegelijk was het effect van bemesting op het $\mathrm{K}$-gehalte bij een hoge CEC veel kleiner dan bij een lage CEC. Daarom wordt voorgesteld systematiek 3 niet in te voeren en wordt voorgesteld het onderstaande advies in te voeren.

In overleg met de Cie Bemesting is op basis van systematiek 2 voor snijmaïs het volgende bemestingsadvies opgesteld (met $a=3$ ).

Tabel S Advies kali-bemesting voor snijmaïs, $\mathrm{kg} \mathrm{K}_{2} \mathrm{O}$ per ha.

\begin{tabular}{|c|c|c|c|}
\hline $\begin{array}{l}\text { Bodem: } \\
\mathrm{K}-\mathrm{CaCl}_{2}\end{array}$ & Opbrengst & & \\
\hline 20 & 200 & 160 & 120 \\
\hline 40 & 200 & 160 & 120 \\
\hline 80 & 140 & 100 & 60 \\
\hline 100 & 80 & 40 & 0 \\
\hline 120 & 20 & 0 & 0 \\
\hline
\end{tabular}




\title{
$1 \quad$ Inleiding
}

\begin{abstract}
Aanleiding
Gras en snijmaïs zijn verreweg de belangrijkste gewassen voor diervoeding in de Nederlandse melkveehouderij sector. De opbrengsten per hectare en de voederwaarde zijn cruciaal om aan de stijgende vraag naar voer van eigen land te kunnen voldoen en de vraag naar niet bedrijfseigen voedermiddelen zoals krachtvoer te minimaliseren. Kalium $(K)$ is belangrijk voor de opbrengst van snijmaïs. Voor een goede opbrengst en een goede benutting van de gegeven stikstof en fosfaat, waarvoor gebruiksnormen gelden, is het belangrijk dat $\mathrm{K}$ niet beperkend is. De fosfaatgebruiksnormen beperken de hoeveelheid mest die per ha kan worden toegediend. Met 40 en $33 \mathrm{~m}^{3}$ rundveedrijfmest wordt respectievelijk 60 en $50 \mathrm{~kg}$ fosfaat gegeven en respectievelijk circa 220 en $180 \mathrm{~kg} \mathrm{~K}{ }_{2} \mathrm{O}$. Dat is lager dan het huidige maximale bemestingsadvies van $300 \mathrm{~kg} \mathrm{~K}{ }_{2} \mathrm{O} / \mathrm{ha}$ bij een lage toestand, waardoor in deze situaties aanvulling met kunstmest nodig zou zijn.
\end{abstract}

In Nederland is het maisareaal ruim 200.000 ha maïs waarvan $80 \%$ in continuteelt. Circa $75 \%$ wordt op zandgrond geteeld en $25 \%$ op klei- en lössgronden. Naar schatting heeft circa $40 \%$ van de percelen met continuteelt een kalitoestand van voldoende of lager en 2 jaar na het laatste grondonderzoek wordt geadviseerd om op zandgrond $300 \mathrm{~kg} \mathrm{~K} \mathrm{~K}_{2} \mathrm{O} / \mathrm{ha}$ te bemesten. Dat betekent dat ruim 52\% van het areaal een advies van $300 \mathrm{~kg} \mathrm{~K}{ }_{2} \mathrm{O} / \mathrm{ha}$ krijgt. Volgens het advies is dan naast de dierlijke mest een aanvulling nodig met $80-120 \mathrm{~kg} \mathrm{~K} \mathrm{~K}_{2} \mathrm{O} / \mathrm{ha}$ uit kunstmest. Dit betekent voor de sector een kostenpost van 3,5 tot 4 miljoen euro (excl. strooikosten).

Wanneer door onderzoek het maximale K-advies daalt door een betere afstemming op de gewasrespons en op de beschikbaarheid van $\mathrm{K}$ in de bodem en er rekening gehouden kan worden met het productiepotentieel van een perceel kan kalibemesting efficiënter kan worden toegepast. Dit verbetert het rendement van de sector.

Om na te gaan of er aanwijzingen zijn dat er verbetering van het kali-bemestingsadvies mogelijk is, is een voorstudie uitgevoerd naar de achtergronden en doelmatigheid van het huidige Kbemestingsadvies voor maïs. De resultaten van deze studie zijn weergegeven in een rapport (Van Schooten et al., 2011). De conclusies uit de voorstudie waren:

- Het huidige bemestingsadvies voor snijmaïs is opgebouwd uit een bodem- en een gewasgericht advies. Het gewasgerichte advies is vooral afgeleid van onderzoek naar korrelmaïs in de jaren 40 en 50 van de vorige eeuw en is daarmee niet meer up-to-date.

- Het bodemgerichte advies hangt af van de kaliafvoer. Er bleek een duidelijk positief verband te bestaan tussen de drogestofopbrengst en de kaliafvoer met de maïs. Doordat de opbrengst van maïs in de afgelopen 15 jaar gemiddeld met $250 \mathrm{~kg}$ ds per ha per jaar is gestegen is ook de kaliafvoer per ha toegenomen.

- In het huidige bemestingsadvies wordt het K-getal gebruikt als maat voor beschikbaarheid. Er is echter een slechte correlatie tussen het K-getal en de gewasrespons. Door het gebruik van het Kgetal is het niet mogelijk rekening te houden met het effect van andere bodemfactoren en nutriënten in de bodem op de beschikbaarheid van $\mathrm{K}$. Er zijn nu analysemethoden beschikbaar waarmee de beschikbaarheid en nalevering van $\mathrm{K}$ beter kan worden geschat en waarbij tevens rekening gehouden kan worden met andere bodemparameters en nutriënten in de bodem.

- De onderzoeksresultaten naar de effecten van K-bemesting in de rij waren niet eenduidig en varieerden van geen effect tot een betere werking met een factor 3 . Het al of niet uitgaan van een verbeterd effect van bemesting in de rij voor kali dient beter onderbouwd te worden.

Aanbevelingen uit de voorstudie waren om:

- af te stappen van het K-getal en overschakelen naar een analysemethode waarmee de intensiteit (op korte termijn beschikbaar) en de capaciteit (op langere termijn beschikbaar) worden bepaald. Hiervoor kan worden voortgeborduurd op de kennis vanuit het graslandonderzoek (Bussink et al., 2011). 
- $\quad$ onderzoek te laten uitvoeren naar de gewasrespons op de K-beschikbaarheid, bepaald met behulp van intensiteit en capaciteit. Daarbij is het gewenst om de efficiëntie van kali toegediend als rijenbemesting mee te nemen. Naar analogie met stikstof en fosfaat zou de efficiëntie hoger kunnen zijn bij toediening in de rij. Bovendien is de verwachting in de praktijk dat steeds meer drijfmest als rijenbemesting zal worden toegediend. Daarmee wordt dus ook steeds meer kali gegeven als rijenbemesting.

De voorstudie gaf aanleiding om veldonderzoek uit te voeren. Het doel van dit veldonderzoek is:

- $\quad$ Een actueel kali-bemestingsadvies voor de teelt van maïs te ontwikkelen.

- Optimaal rekening houden met bodemfactoren (w.o. nutriënten in de bodem, pH) die van invloed zijn op de K-beschikbaarheid.

- Optimaal rekening houden met het productiepotentieel van een perceel.

\section{$1.1 \quad$ Vraagstelling}

In dit onderzoek worden de volgende vragen beantwoord:

1. Wat is de relatie tussen drogestofopbrengst en het kaliumgehalte in het gewas en de bodemanalyse en gegeven K-bemesting?

2. Wat is het effect van bodemparameters als $\mathrm{pH}, \mathrm{Mg}$-gehalte, Cation Exchange Capacity (CEC $\left.{ }^{1}\right)$ en CEC-bezetting?

3. Wat is de efficiëntie van $K$, toegediend als rijenbemesting?

Om deze vragen te beantwoorden is gedurende twee jaar onderzoek uitgevoerd via detailonderzoek op 3 proeflocaties en miniproeven op 20 praktijklocaties. De vragen 1 en 3 zullen worden beantwoord met de detailproeven, vragen 1 en 2 met de miniproeven.

\footnotetext{
${ }^{1}$ De kationenomwisselinascapaciteit, afaekort tot CEC (Cation Exchanqe Capacitv), is de capaciteit van de bodem om positief geladen ionen uit te wisselen met de bodemoplossing.
} 


\section{Materiaal en methode}

\section{$2.1 \quad$ Detailproeven}

In 2015, 2016 en 2017 zijn op drie locaties proefvelden met het gewas snijmaïs aangelegd: twee op zandgrond, Marwijksoord (MW) en Vredepeel (VP), en één op kleigrond, Wageningen (Wg). De locaties waren geselecteerd op onder andere een relatief lage $\mathrm{K}$-toestand $\left(\mathrm{K}-\mathrm{CaCl}_{2} \leq 50\right)$. Het plan was om in 2015 en 2016 de proeven uit te voeren maar in 2016 hebben de weersomstandigheden (wateroverlast) de proeven op de locaties Vredepeel (zand) en Wageningen (klei) verstoord (zie hoofdstuk resultaten). In 2017 is op deze locaties de proef opnieuw uitgevoerd.

In 2015 werden de volgende 20 combinaties van de behandelingsfactoren "rundveedrijfmest" (rdm) en "K-gift uit kunstmest" aangelegd:

1) Geen $\mathrm{rdm} \times 0,40,80,160$ en $320 \mathrm{~kg} \mathrm{~K}{ }_{2} \mathrm{O} / \mathrm{ha}$ uit kunstmest volvelds

2) Geen $\mathrm{rdm} \times 40,80$ en $160 \mathrm{~kg} \mathrm{~K} 2 \mathrm{O} /$ ha uit kunstmest rijenbemesting

3) $20 \mathrm{~m}^{3} /$ ha rdm volvelds $\times 0,40,80$ en $160 \mathrm{~kg} \mathrm{~K}{ }_{2} \mathrm{O} / \mathrm{ha}$ uit kunstmest volvelds

4) $20 \mathrm{~m}^{3} /$ ha rdm volvelds $\times 40,80$ en $160 \mathrm{~kg} \mathrm{~K} \mathrm{~K}_{2} \mathrm{O} /$ ha uit kunstmest rijenbemesting

5) $20 \mathrm{~m}^{3} /$ ha rdm rijenbemesting $\times 0,40$ en $80 \mathrm{~kg} \mathrm{~K} 2 \mathrm{O} / \mathrm{ha}$ uit kunstmest volvelds

6) $20 \mathrm{~m}^{3} /$ ha rdm rijenbemesting $\times 40$ en $80 \mathrm{~kg} \mathrm{~K}{ }_{2} \mathrm{O} / \mathrm{ha}$ uit kunstmest rijenbemesting

Na 1 jaar bleek dat kunstmest rijenbemesting met kali geen voordelen biedt. Daarom is deze vervangen door een behandeling een lagere $\mathrm{N}$-gift $(100 \mathrm{~kg} / \mathrm{ha})$. De stikstofbemesting bij mais is in de praktijk soms lager dan $150 \mathrm{~kg} \mathrm{~N} / \mathrm{ha}$. Daarnaast was er in de praktijk een discussie over de $\mathrm{N}$-gift en de mogelijke interactie met K-gift, en wel of een hoge $\mathrm{N}$-gift een lage K-gift zou kunnen compenseren. Daarom zijn in 2016 en 2017 naast de behandelingen met een N-gift van $200 \mathrm{~kg}$ per ha ook behandelingen met een $\mathrm{N}$-gift van $100 \mathrm{~kg}$ per ha aangelegd. Uit kostenoverweging is het aantal objecten echter gelijk gehouden. Op basis van de resultaten van 2015 is er voor gekozen om de volgende drie "kali"objecten in 2016 en 2017 te laten vervallen: bij 4) $20 \mathrm{~m}^{3}$ rdm volvelds $+160 \mathrm{~kg}$ $\mathrm{K}_{2} \mathrm{O}$ uit kunstmest rijenbemesting, bij 6) $20 \mathrm{~m}^{3} \mathrm{rdm}$ rijenbemesting $+40 \mathrm{~kg} \mathrm{~K}_{2} \mathrm{O}$ uit kunstmest rijenbemesting en 6) volledig. Dit resulteerde voor 2016 en 2017 in:

1a) Geen $\mathrm{rdm} \times 0,40,80,160$ en $320 \mathrm{~kg} \mathrm{~K} \mathrm{~K}_{2} \mathrm{O} / \mathrm{ha}$ uit kunstmest volvelds $+200 \mathrm{~kg} \mathrm{~N} / \mathrm{ha}$

1b) Geen $\mathrm{rdm} \times 40,80 \mathrm{~kg} \mathrm{~K} 2 \mathrm{O} / \mathrm{ha}$ uit kunstmest volvelds $+100 \mathrm{~kg} \mathrm{~N} / \mathrm{ha}$

2) Geen $\mathrm{rdm} \times 40,80$, en $160 \mathrm{~kg} \mathrm{~K} 2 \mathrm{O} / \mathrm{ha}$ uit kunstmest rijenbemesting $+200 \mathrm{~kg} \mathrm{~N} / \mathrm{ha}$

3) $20 \mathrm{~m}^{3} / \mathrm{ha} \mathrm{rdm}$ volvelds $\times 0,40,80$ en $160 \mathrm{~kg} \mathrm{~K}{ }_{2} \mathrm{O} / \mathrm{ha}$ kunstmest volvelds $+200 \mathrm{~kg} \mathrm{~N} / \mathrm{ha}$

4) $20 \mathrm{~m}^{3} / \mathrm{ha}$ rdm volvelds $\times 40$ en $80 \mathrm{~kg} \mathrm{~K} 2 \mathrm{O} /$ ha kunstmest rijenbemesting $+200 \mathrm{~kg} \mathrm{~N} / \mathrm{ha}$

5) $20 \mathrm{~m}^{3} / \mathrm{ha}$ rdm rijenbemesting $\times 0$, 40 en $80 \mathrm{~kg} \mathrm{~K}{ }_{2} \mathrm{O} / \mathrm{ha}$ kunstmest volvelds $+200 \mathrm{~kg} \mathrm{~N} / \mathrm{ha}$

Het proefontwerp was een gewarde blokkenproef in 4 herhalingen. De proefveldschema's en algemene proefveldgegevens als ras en plotgrootte staan per locatie in Bijlage 1.

Voor aanvang van de proef zijn grondmonsters genomen (laag 0-25 cm) en vond er een mestanalyse plaats.

$\mathrm{Bij}$ alle behandelingsfactoren vond fosfaataanvulling plaats tot $65 \mathrm{~kg} \mathrm{P}_{2} \mathrm{O}_{5}$ per ha in de vorm van tripelsuperfosfaat $\left(48 \% \mathrm{P}_{2} \mathrm{O}_{5}\right)$. Als minerale kalimeststof is kali-60 gebruikt $\left(60 \% \mathrm{~K}_{2} \mathrm{O}\right)$.

$\mathrm{Bij}$ het berekenen van de totale $\mathrm{N}$ - en P-bemesting is de gift uit rdm meegerekend. Voor de werking van de $\mathrm{N}$ uit volvelds toegediende $\mathrm{rdm}$ is gerekend met $57,5 \%$, de werking in de rij is vermenigvuldigd met 1,25 ten opzichte van de volveldse toediening. Alle gegeven $\mathrm{P}$ en $\mathrm{K}$ is als $100 \%$ werkzaam verondersteld. Bij elke behandeling is tijdens het zaaien ca. $25 \mathrm{~kg} \mathrm{~N}$ per ha als rijenbemesting toegediend. De overige $\mathrm{N}$ en $\mathrm{P}$ is breedwerpig aangevuld. Met een N/S meststof (KAS-Zwavel) is ca. $15 \mathrm{~kg} \mathrm{~S}$ uit kunstmest gegeven. De N-bemesting is sluitend gemaakt via toediening van KAS.

De volgende parameters zijn geanalyseerd in grond, drijfmest en gewas:

- Grond: org. stof, CEC en CEC-bezetting, NLV, SLV, C/N, P-AL, bodemleven en P, K, Mg, Na op 
basis van extractie met $0,01 \mathrm{M} \mathrm{CaCl}_{2}$ en $\mathrm{K}-\mathrm{HCl}$ via $0,1 \mathrm{M} \mathrm{HCl}$

- Drijfmest: Ds, ruw as, Ntotaal, $\mathrm{NH}_{4}-\mathrm{N}, \mathrm{P}_{2} \mathrm{O}_{5}, \mathrm{~K}_{2} \mathrm{O}, \mathrm{MgO}$ en $\mathrm{Na}_{2} \mathrm{O}$ en $\mathrm{C} / \mathrm{N}$

- Gewas: drogestof, ruw eiwit, kalium, magnesium, natrium calcium, fosfor, zwavel, mangaan, zink, ijzer, koper en zwavel. Alleen kunstmestobjecten: VEM, DVE, OEB, SW, NDF, Zetmeel

De proefveldwerkzaamheden zijn per locatie bijgehouden in een logboek. Bij de oogst is per object een netto strook geoogst (gehakseld) met een proefveldhakselaar. De opbrengst is gewogen en bemonsterd. De monsters zijn gebruikt voor zowel een drogestofbepaling als voor een mineralen- en voederwaardeanalyse. Tijdens de groei is het proefveld enige keren bezocht om eventuele bijzonderheden waar te kunnen nemen.

\subsection{Miniproeven}

Op basis van grondonderzoek door Eurofins zijn 20 bedrijven (12 op zand en 8 op klei) geselecteerd die in de winter van 2014/2015 grondonderzoek hebben laten uitvoeren op minimaal twee percelen en waarbij er tussen de percelen een duidelijk verschil was in K-toestand. In principe deden zoveel mogelijk van de 2015 percelen ook mee in 2016 en is de proef op een ander deel van het perceel aangelegd dan in 2015. Als er bedrijven/percelen uit vielen dan zijn die vervangen door andere bedrijven/percelen.

Op de 20 praktijkbedrijven zijn 6 behandelingen aangelegd:

- Geen rdm, $0 \mathrm{~kg} \mathrm{~K}{ }_{2} \mathrm{O} / \mathrm{ha}$

- Geen rdm, $40 \mathrm{~kg} \mathrm{~K} \mathrm{~K}_{2} \mathrm{O} / \mathrm{ha}$

- Geen rdm, $80 \mathrm{~kg} \mathrm{~K}{ }_{2} \mathrm{O} / \mathrm{ha}$

- Geen rdm, $160 \mathrm{~kg} \mathrm{~K}{ }_{2} \mathrm{O} / \mathrm{ha}$

- $\operatorname{Rdm}\left(\sim 40 \mathrm{~m}^{3} / \mathrm{ha}\right), 0 \mathrm{~kg} \mathrm{~K}{ }_{2} \mathrm{O} / \mathrm{ha}$

- $\operatorname{Rdm}\left(\sim 40 \mathrm{~m}^{3} / \mathrm{ha}\right), 80 \mathrm{~kg} \mathrm{~K} \mathrm{~K}_{2} \mathrm{O} / \mathrm{ha}$

In totaal zijn er 240 veldjes per jaar gepland zowel in 2015 als 2016 .

Bij de opzet van de miniproeven is de veehouders gevraagd om op één strook een vastgestelde hoeveelheid $\mathrm{rdm}$ (bijvoorbeeld $40 \mathrm{~m}^{3} / \mathrm{ha}$ ) toe te dienen en op een "aansluitende" strook géén mest toe te dienen. Deze strook diende daarbij voorbij de kopakker van het perceel te liggen. Elke miniproef bevatte zo een strook met rdm en zonder rdm.

Op elk deelnemend bedrijf is de mest bemonsterd tijdens de periode van mest uitrijden. Kort na de zaai van de mais zijn de kalibemestingstrappen aangelegd en is ook een grondmonster genomen van het "geen mest deel" voor uitgebreid grondonderzoek zowel in 2015 als 2016 omdat de specifieke plek kon afwijken van het grondonderzoek van het gehele perceel.

De aan te leggen veldjes hadden een afmeting van 3 bij 8 meter. Alle veldjes kregen een basisbemesting met stikstof (200-250 kg N/ha) en fosfaat ( $65 \mathrm{~kg} \mathrm{P} \mathrm{P}_{5} / \mathrm{ha}$ ). Er is vanuit gegaan dat

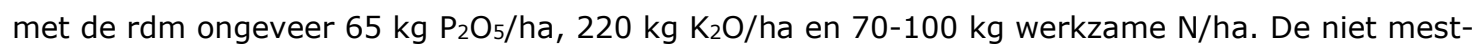

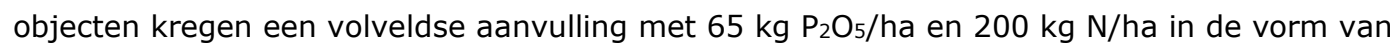
respectievelijk tripelsuperfosfaat en KAS. De rdm-objecten kregen $100 \mathrm{~kg} \mathrm{~N} / \mathrm{ha}$ in de vorm van KAS. Alle percelen kregen bij de zaai van de mais een $\mathrm{N}$-gift in de rij. Als kalimeststof werd korn-kali gebruikt $\left(40 \% \mathrm{~K}_{2} \mathrm{O}\right.$, bevat ook zwavel).

Bij deelnemende ondernemers zijn alle perceelshandelingen opgevraagd, inclusief het gebruikte maisras, de voorvrucht en de hoeveelheid $\mathrm{N}$ in de rij.

In het najaar, 2-14 dagen voorafgaand aan de praktijkoogst, zijn de eindopbrengst en de gewassamenstelling bepaald door per behandeling twee stroken van 2,5 meter te oogsten. In het veld is per behandeling van beide stroken het vers gewicht bepaald met behulp van een unster en een driepoot. De mais is met een tuinhakselaar gehakseld. Aansluitend vond sub-bemonstering plaats om per behandeling ongeveer $1 \mathrm{~kg}$ vers materiaal te verkrijgen. Dit monster is naar Eurofins gestuurd voor de bepaling van het drogestofgehalte en de minerale samenstelling. Op basis van het 
drogestofgehalte, het vers gewicht en de bemonsterde perceelsoppervlakte is de drogestofopbrengst berekend.

De volgende parameters worden meegenomen worden in de analyses van grond, mest en gewas:

- Grond: gehaltes aan organische stof, CEC en CEC-bezetting, NLV, SLV, C/N ratio, P-AL, bodemleven en $\mathrm{P}, \mathrm{K}, \mathrm{Mg}, \mathrm{Na}$ op basis van extractie met $0,01 \mathrm{M} \mathrm{CaCl}_{2}$ en $\mathrm{K}-\mathrm{HCl}$ via $0,1 \mathrm{M} \mathrm{HCl}$.

- Mestonderzoek: gehaltes aan drogestof, organische stof, ruw as, $\mathrm{N}$-totaal, $\mathrm{NH}_{4}-\mathrm{N}_{1} \mathrm{P}_{2} \mathrm{O}_{5}, \mathrm{~K}_{2} \mathrm{O}, \mathrm{MgO}$ en $\mathrm{Na}_{2} \mathrm{O}$ en $\mathrm{C} / \mathrm{N}$ ratio.

- Gewas-analyse: gehaltes aan drogestof, ruw eiwit, kalium, magnesium, natrium calcium, fosfor, zwavel, mangaan, zink, ijzer en koper.

\subsection{Statistische analyse}

De detailproeven zijn eerst separaat geanalyseerd om de invloeden van de K-bemesting, de vorm (organisch en mineraal), en de plaatsing (volvelds of in de rij) te toetsen. Aansluitend zijn de detailproeven en miniproeven integraal geanalyseerd (zie h 5.1 voor nadere toelichting). Beoogd is om een verklarend model te ontwikkelen waarbij de (K-)opbrengst en K-gehalte worden verklaard op basis van de gerealiseerde bemestingen en bodemfactoren. Dit model plus de analyseresultaten van de detailproef zijn gebruikt als basis voor een nieuw te formuleren K-bemestingsadvies. De statistische analyse is uitgevoerd met behulp van het statistische programma Genstat (VSN International, 2013).

Voor de detailproeven en de miniproeven is de statistische analyse uitgevoerd met lineaire regressie en REML (reduced maximum likelihood; Harville, 1977) als methode om de parameters te berekenen. REML is een methode waarbij (lineaire) modellen worden ontwikkeld die zo goed mogelijk bij de data passen. Zo'n model bestaat uit een fixed (=systematisch) deel en een random deel (=toevallig). In het fixed deel komen de factoren die ingesteld zijn en kwantificeerbaar zijn. In het random deel komen factoren waarvan bekend is dat ze invloed hebben maar die niet gekwantificeerd kunnen worden. Via REML kan daardoor rekening worden gehouden met herhaling en plot binnen locatieeffecten. REML is geschikt om ongebalanceerde datasets te analyseren.

\subsubsection{Detailproeven}

De analyse van de detailproeven heeft 2 doelen: 1) bepalen welke behandelingen (kali-bemesting, rijenbemesting, etc.) significant zijn op verschillende kenmerken (drogestofopbrengst, kali-gehalte, kali-opbrengst, etc.) en 2) kwantificeren van de effecten. De analyse is dan ook in twee stappen te scheiden:

1. Een lineair model wordt gedefinieerd met behandelingen en interacties die in de proef voorkwamen. Vervolgens worden niet-significante interacties verwijderd. Deze stap levert antwoord op de vraag welke behandelingen significante effecten oplevert.

2. Uit het lineaire model van stap 1 worden ook de niet-significante hoofdeffecten verwijderd.

Parameters worden geschat. Met dit model kunnen de grootte van de effecten van significante factoren worden gekwantificeerd en tussen de locaties worden vergeleken.

Het lineaire model dat voor het begin van stap 1 is gedefinieerd als:

Locatie.oogstjaar + Locatie.oogstjaar.mest_type_KMOM + Locatie.oogstjaar.mest_type_KMOM.rdm_plaatsing + Locatie.oogstjaar.Stikstofniveau + Locatie.oogstjaar.K2Ogift_KM + Locatie.oogstjaar.K2Ogift_KM.km_plaatsing+ Locatie.oogstjaar.K2Ogift_KM.rdm_plaatsing

Waarin factoren

- Locatie

- Oogstjaar

- Mest_type_KMOM: kunstmest of dierlijke mest

- $\quad$ Rdm_plaatsing: plaatsing van dierlijke mest is volvelds of in de rij 
- Stikstofniveau: hoogte bemesting met werkzame stikstof uit dierlijke mest+kunstmest, 100 of $200 \mathrm{~kg} \mathrm{~N} / \mathrm{ha}$

- $\quad$ K2Ogift_KM: gift met $\mathrm{K}_{2} \mathrm{O}-$ kunstmest in $\mathrm{kg} \mathrm{K}_{2} \mathrm{O} / \mathrm{ha}$

- $\quad \mathrm{Km} \_$plaatsing: plaatsing van kunstmest is volvelds of in de rij.

Het random model in deze analyse zijn de verschillen tussen de herhalingen per oogstjaar-locatie combinatie. Dit is uitgedrukt in de interactie-term Locatie.oogstjaar.herhaling.

De rest-variantie die dan nog overblijft is de toevallige variantie tussen de veldjes, uitgedrukt in de interactie-term: Locatie.oogstjaar.veldnr. De rest-variantie is gebruikt om te toetsen of de gemeten effecten van behandelingen groter zijn dan de toevallige effecten, ofwel of effecten significant zijn. De betekenis van een factor is ten opzichte van een referentiewaarde. De referentie hangt af van de andere factoren die in het model zijn opgenomen. De betekenis en de referentie in de analyse zijn opgenomen in onderstaande tabel 1.

Tabel 1 Betekenis en referentie van opgenomen factoren in statistische analyse.

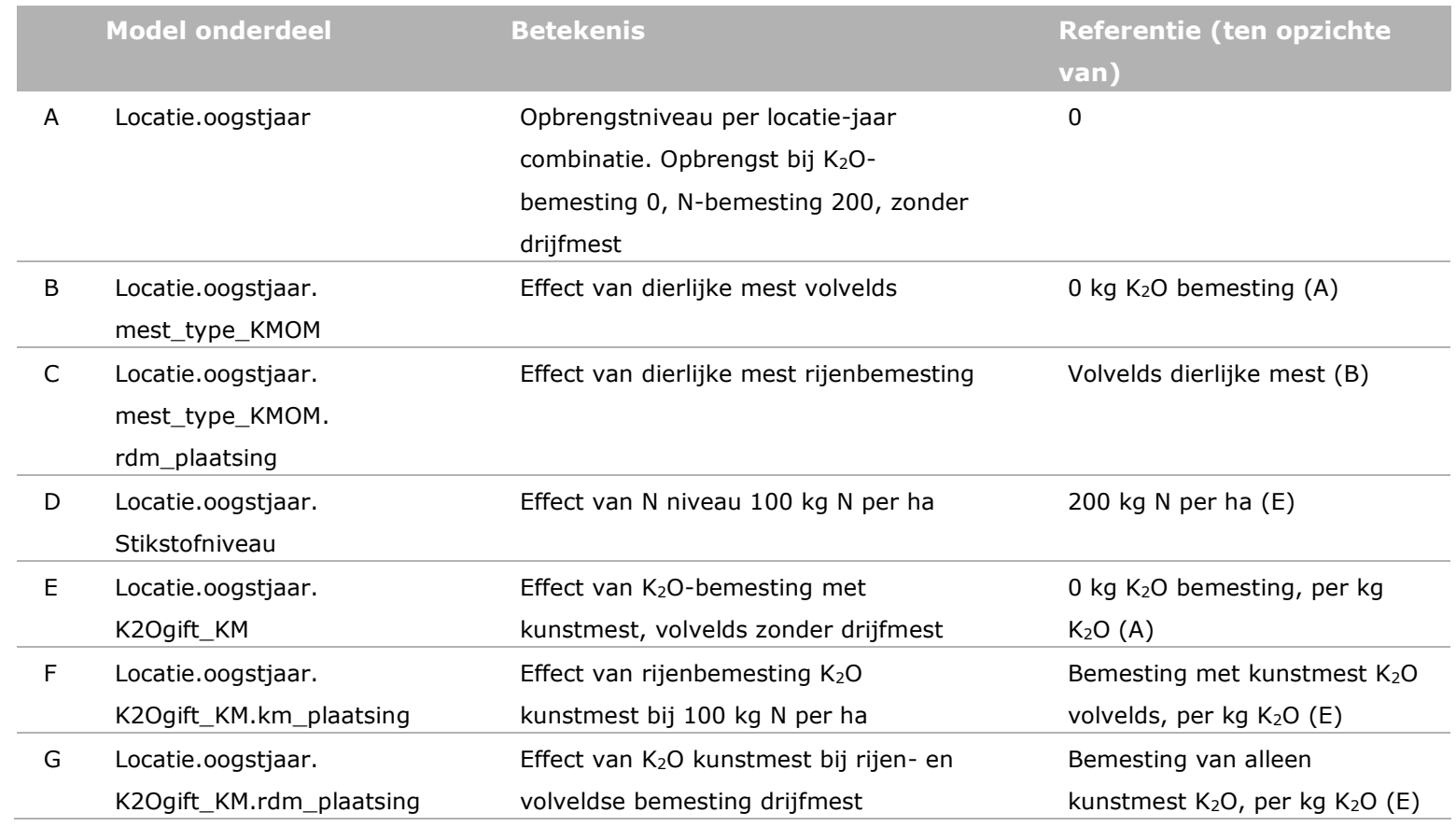

Vereenvoudigd ziet het model er als volgt uit:

$\mathrm{Y}=\mathrm{A}+\mathrm{B}+\mathrm{C}+\mathrm{D}+(\mathrm{E}+\mathrm{F}+\mathrm{G}) * \mathrm{~kg} \mathrm{~K} \mathrm{~K}_{2} \mathrm{O} / \mathrm{ha}$

$Y$ : kenmerk zoals drogestofopbrengst, K-gehalte, K-opbrengst etc.

A, B, C en D zijn discrete, additieve factoren. Dat wil zeggen dat ze opgeteld worden als ze significant zijn of de waarde 0 krijgen als ze niet significant zijn.

$\mathrm{E}$, $\mathrm{F}$ en $\mathrm{G}$ zijn continu, dat wil zeggen dat ze vermenigvuldigd worden met de bemestingsgift in $\mathrm{kg} \mathrm{K}_{2} \mathrm{O}$ per ha als ze significant zijn en de waarde 0 krijgen als ze niet significant zijn.

\subsubsection{Miniproeven en detailproeven integraal}

De analyse van de miniproeven en de detailproeven samen heeft doel het verklaren van de drogestofopbrengst, kaliopbrengst en of K-gehalte uit bodem- en bemestingsparameters, waaronder de kalibemesting en de bodemkengetallen voor kali. Uit de te verkrijgen relaties kan vervolgens afgeleid worden hoe kali-bodemparameters en de kalibemesting van invloed zijn op de opbrengst, de kalionttrekking en de het K-gehalte. Deze relaties vormen de basis voor een op te stellen advies. De verschillende analyse-stappen zijn afhankelijk van de inzichten die verkregen worden tijdens de analyse. In het hoofdstuk resultaten (5.1) worden de analyse-stappen verder verklaard. 


\subsection{Uitvoering detailproeven}

\subsubsection{Locaties detailproeven}

De proeven op zandlocaties zijn aangelegd op een perceel van proefbedrijf Kooijenburg te Marwijksoord en proefbedrijf Vredepeel te Vredepeel. De proef op klei is aangelegd op een perceel van proefbedrijf Unifarm te Wageningen.

De proeven zijn in 2016 op de locaties Vredepeel en Wageningen mislukt door wateroverlast als gevolg van hevige onweersbuien in juni. De mais had duidelijk te lijden gehad van het water dat gedurende langere tijd op het veld is blijven staan. Daarom zijn de data van 2016 van die locaties niet gebruikt en is de proef in 2017 herhaald op zowel Vredepeel als Wageningen. De exacte locatie van de proeven (GPS-coördinaten) is weergegeven in tabel 2.

De weersomstandigheden tijdens de proefjaren zijn beschreven in $\mathrm{H} 2.6$ en in detail in bijlage 2 .

In 2017 is op de kleilocatie door een verkeerde interpretatie van de bemestingscode afgeweken van het proefplan. De code volveldse bemesting is geïnterpreteerd als varkensdrijfmest; er is derhalve in 2017 zowel rundveedrijfmest als varkensdrijfmest in de rij toegediend. Er is bij de bemesting gecorrigeerd voor de eventuele verschillen in toegediende $\mathrm{N}$ en rekening gehouden met de gehalten.

Tabel 2 GPS-coördinaten van de locaties.

\begin{tabular}{|c|c|c|c|}
\hline \multirow[t]{3}{*}{ Jaar } & & Locaties & \\
\hline & Vredeweg 1A & Marwijksoord 4 & Bornsesteeg 48 \\
\hline & $5816 \mathrm{AJ}$ & $9448 \times B$ & $6708 \mathrm{PE}$ \\
\hline 2015 & $51^{\circ} 32^{\prime} 27,5^{\circ} 51^{\prime} 38$ & $52^{\circ} 58^{\prime} 03,6^{\circ} 39^{\prime} 17$ & $51^{\circ} 58^{\prime} 23,5^{\circ} 38^{\prime} 32$ \\
\hline 2016 & $51^{\circ} 33^{\prime} 39,5^{\circ} 51^{\prime} 14$ & $52^{\circ} 37^{\prime} 34,6^{\circ} 39^{\prime} 18$ & $51^{\circ} 57^{\prime} 25,5^{\circ} 38^{\prime} 04$ \\
\hline
\end{tabular}

\subsubsection{Bodemanalyses en bemesting detailproeven}

Voor aanvang van de proef is op elke locatie een grondmonster gestoken van de laag 0-25 cm-mv. De resultaten van de grondmonsteranalyse zijn per jaar weergegeven in de tabel 3. De locaties op Vredepeel en Marwijksoord zijn de zandlocaties, met een lagere $\mathrm{pH}$ dan Wageningen (rivierklei). Het was de bedoeling om percelen te gebruiken met weinig beschikbare kali. Dit is in het algemeen goed gelukt, alleen op de locatie Marwijksoord in 2015 was de kalibeschikbaarheid wat aan de hoge kant. Het organische stofgehalte lag op Vredepeel duidelijk lager dan op Marwijksoord. 
Tabel 3 Bodemanalyses van de locaties in 2015, 2016 en 2017.

\begin{tabular}{|c|c|c|c|c|c|c|}
\hline & & 2015 & & 2016 & 2017 & \\
\hline Perceel & Van Hoof & $19-26$ & KO4 & $\mathrm{HO}-4$ & $\begin{array}{c}\text { 't Ven } \\
\text { Cornelissen }\end{array}$ & LA-08 \\
\hline Monsterdatum & 25 maart & 12 mei & 10 maart & 8 maart & 2 februari & 12 januari \\
\hline Organische stof (\%) & 3,5 & 5,1 & 5,9 & 4,5 & 3,2 & 3,4 \\
\hline $\mathrm{pH}$ & 5,2 & 5,1 & 6,3 & 4,9 & 5,3 & 6,8 \\
\hline Klei-humus mmol+/kg) & 90 & 57 & 294 & 50 & 48 & 237 \\
\hline CEC-bezetting (\%) & 80 & 94 & 98 & 90 & 92 & 99 \\
\hline $\begin{array}{l}\text { N-bodemvoorraad } \\
(\mathrm{mg} / \mathrm{kg})\end{array}$ & 1120 & 1450 & 3270 & 1190 & 1150 & 1980 \\
\hline NLV (kg N/ha) & 24 & 65 & 175 & 28 & 50 & 109 \\
\hline $\mathrm{K}-\mathrm{HCL}\left(\mathrm{mg} \mathrm{K}_{2} \mathrm{O} / 100 \mathrm{~g}\right)$ & 8 & 12 & 14 & 9 & 9 & 26 \\
\hline Mg-PAE (mg Mg/kg) & 83 & 71 & 167 & & 109 & 200 \\
\hline SLV (kg S/ha) & & & 17 & 5 & 12 & 11 \\
\hline S-PAE (mg S/kg) & 3,2 & 4,4 & & & 7 & 16 \\
\hline B-PAE ( $\mu \mathrm{g} \mathrm{B/kg)}$ & 370 & 124 & 194 & $\mathrm{HO}-4$ & 102 & 268 \\
\hline
\end{tabular}

Op een aantal objecten is dierlijke mest toegediend. De mest is voor toediening geanalyseerd. De analyseresultaten zijn voor de 3 proefjaren weergegeven in tabel 4. Zoals eerder vermeld is in 2017 op locatie Wageningen naast rundveedrijfmest ook varkensdrijfmest toegepast. De stikstof- en fosfaatgehaltes van de varkensdrijfmest in 2017 zijn zoals verwacht hoger dan die van de rundveedrijfmest. Bij het berekenen van de totale $\mathrm{N}$ - en $\mathrm{P}$-bemesting is hiervoor gecorrigeerd.

Tabel 4 Samenstelling toegepaste rundveedrijfmest in 2015, 2016 en 2017 (in $\mathrm{g} \mathrm{kg}^{-1}$ ).

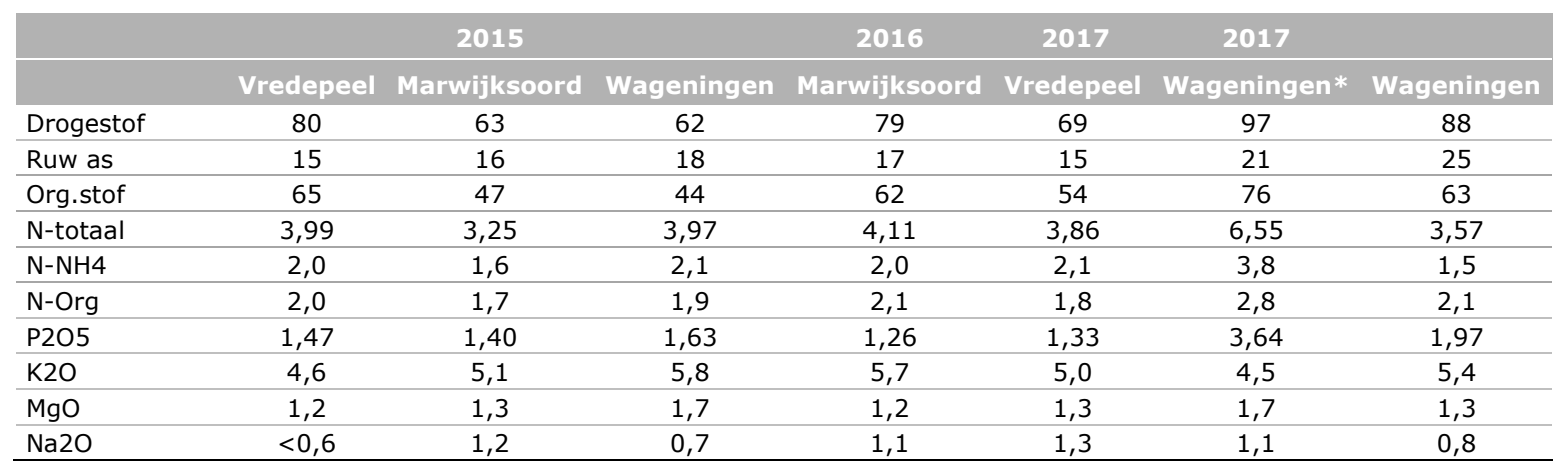

* varkensdrijfmest

\subsubsection{Uitvoering}

De proefbedrijven hebben van alle werkzaamheden een logboek bijgehouden. In tabel 5 tot en met 7 staan alle werkzaamheden van de geslaagde proeven per proeflocatie vermeld.

De bemesting met dierlijke mest werd tussen 10 april en 11 mei uitgevoerd, de inzaai tussen 28 april en 21 mei. De bemesting met kunstmest vond plaats op dezelfde dag of enkele dagen na de toediening van de dierlijke mest behalve in Wageningen 2017, daar vond de bemesting met kunstmest (ruim) 2 weken na de toediening van dierlijkee mest plaats. De proefveldhouder beregende het perceel als hij het nodig achtte, op Vredepeel in 2015 en op Wageningen in 2017. 
Tabel 5 Teeltactiviteiten locatie Vredepeel.

$\begin{array}{lll}\text { Activiteit } & & \text { Vredepeel } \\ \begin{array}{l}\text { Bemesting runderdrijfmest: rijenbemesting } \\ \text { met Evers rijeninjecteur en volvelds bemesting } \\ \text { met bouwlandinjecteur }\end{array} & 20 \text { april } & 10 \text { april volvelds, } 12 \text { april } \\ \text { rijenbemesting }\end{array}$

Tabel 6 Teeltactiviteiten locatie Marwijksoord.

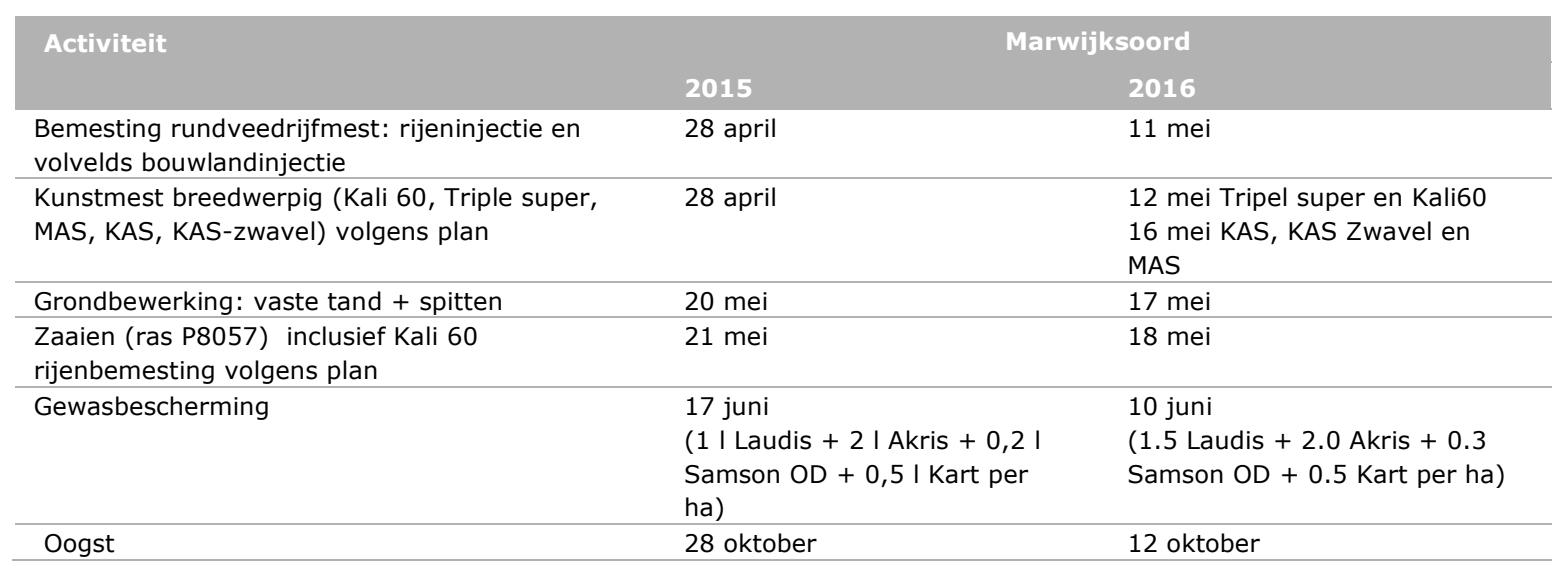

Tabel $7 \quad$ Teeltactiviteiten locatie Wageningen.

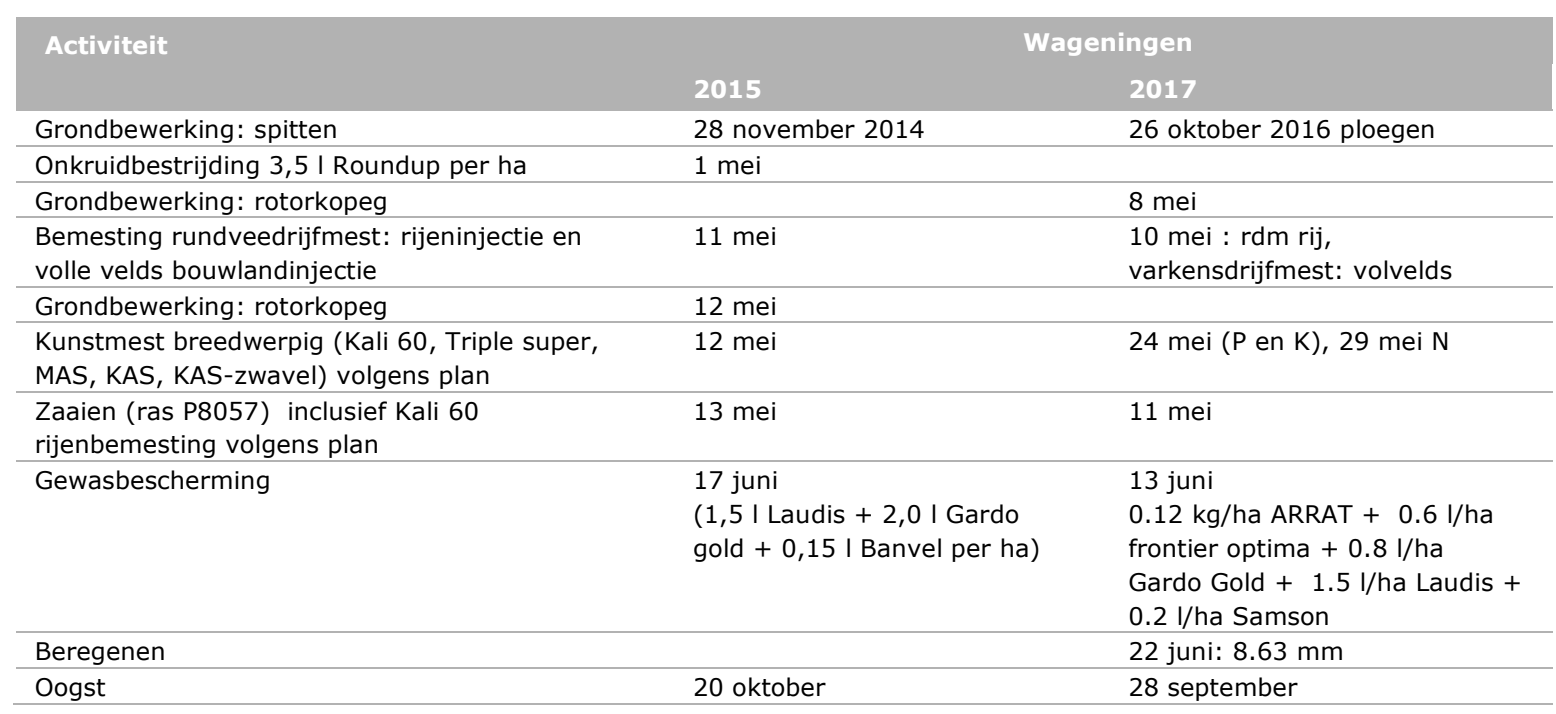

\subsection{Uitvoering miniproeven}

In 2015 hebben 19 bedrijven meegedaan, waarvan 17 met elk twee percelen, 1 met 1 perceel en 1 met 4 percelen. In 2016 hebben 20 bedrijven meegedaan, waarvan 17 met elk twee percelen, 2 met 1 
perceel en 1 met 4 percelen. Op het bedrijf met 4 percelen lagen de percelen ver uit elkaar. In Tabel 8 is de verdeling over de grondsoorten weergegeven. De ligging van de bedrijven is in figuur 1 weergegeven. Twee bedrijven uit 2015 deden niet mee in 2016. Daarvoor zijn nieuwe bedrijven gevonden.

Tabel $8 \quad$ Verdeling van de perceel locaties in 2015 en 2016.

\begin{tabular}{lll} 
Grondsoort & 2015 & 2016 \\
Zand & 24 & 25 \\
\hline Rivierklei & 10 & 11 \\
\hline Zeeklei & 5 & 3 \\
\hline
\end{tabular}

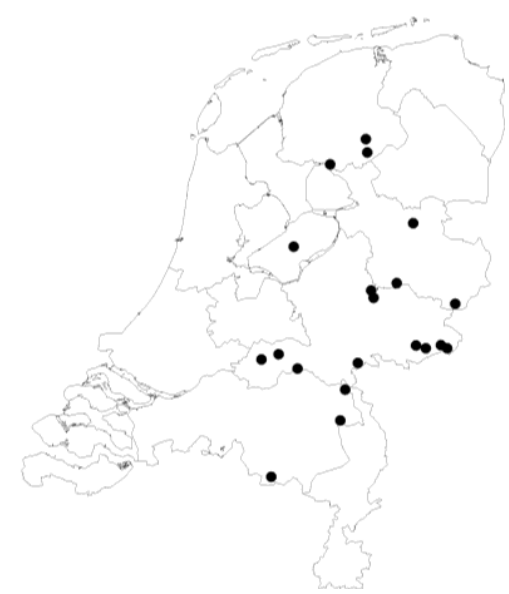

Figuur $1 \quad$ Ligging van locaties miniproeven.

Bij de uitvoering zijn kleine afwijkingen ten aanzien van het werkplan opgetreden. Zowel in 2015 als 2016 bleek het niet mogelijk om op 3 percelen (rivierklei) dierlijke mest toe te dienen zonder forse berijdingsschade. Op deze percelen zijn de drijfmestbehandelingen komen te vervallen. Wel is er een extra kalitrap aangelegd van $320 \mathrm{~K}_{2} \mathrm{O} / \mathrm{ha}$. Daarnaast is in 2015 op 1 kleiperceel een afwijkende bemesting uitgevoerd, waarbij geen drijfmest is gegeven maar in tweevoud 160 en $320 \mathrm{~kg} \mathrm{~K}_{2} \mathrm{O}$ per ha is gegeven.

In 2015 zijn konden van 4 percelen geen drogestofopbrengsten worden bepaald door labfouten (3) en 1 mislukt veldje. In 2016 ontbrak van 1 perceel de opbrengst. In totaal resulteerde dit over beide jaren in netto in 454 maisstroken op 39 bedrijven. In 2016 zijn er lokaal zware buien geweest. Een aantal velden zijn gecontroleerd op schade. Geconstateerd werd dat er uiteindelijk geen duidelijke schade was.

\subsection{Weersomstandigheden}

Van de detailproeven zijn van de drie proefjaren per locatie weergegeven:

- de gemiddelde etmaaltemperatuur per maand gedurende de proefjaren en gemiddelde etmaaltemperatuur per maand over 30 jaar (Figuur 2, links)

- $\quad$ het cumulatieve neerslagoverschot (neerslag minus verdamping) per maand en het 30-jarig gemiddelde voor de locatie. (Figuur 2, rechts). 
Eelde, gemiddelde etmaal temperatuur

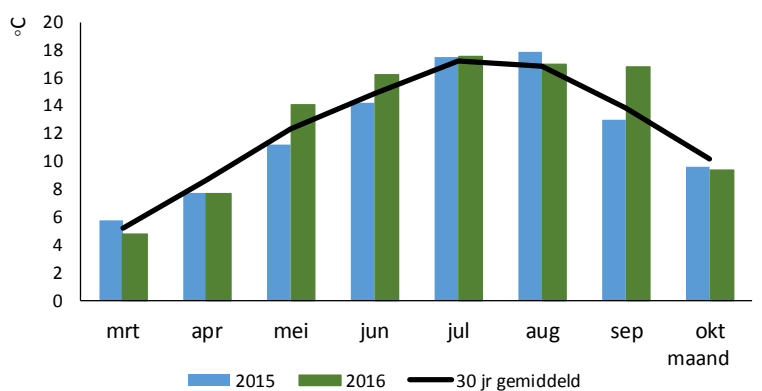

Eindhoven, gemiddelde etmaal temperatuur

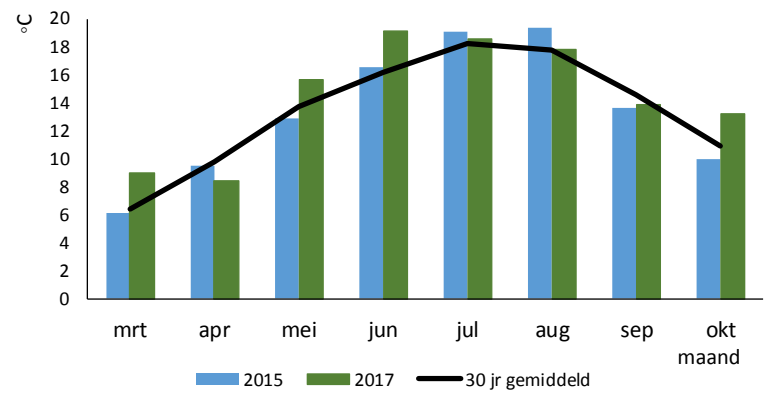

Deelen, gemiddelde etmaal temperatuur

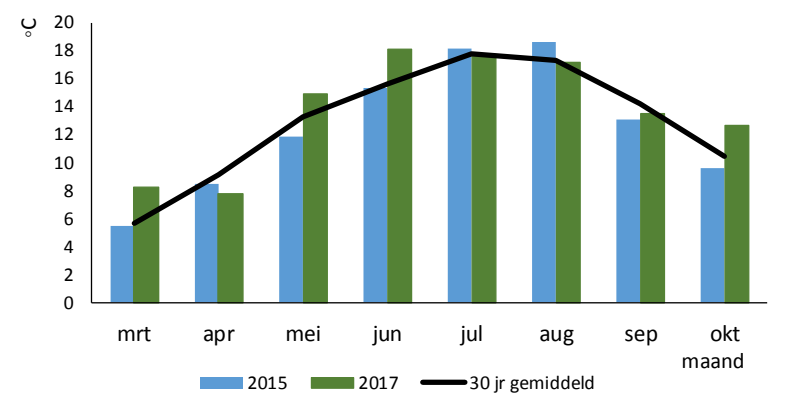

Eelde, cumulatief neerslagoverschot

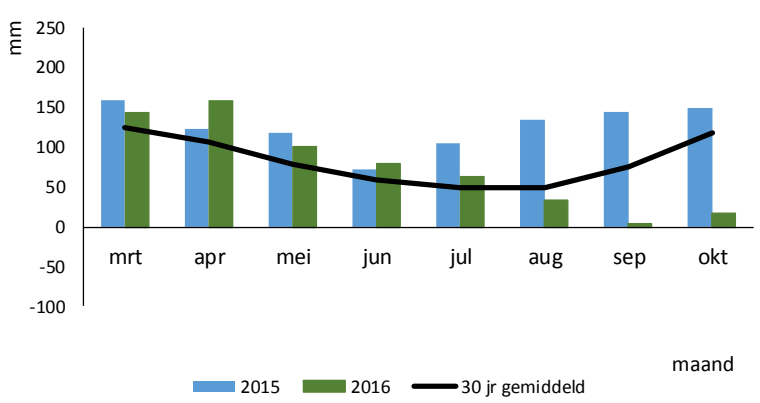

Eindhoven, cumulatief neerslagoverschot

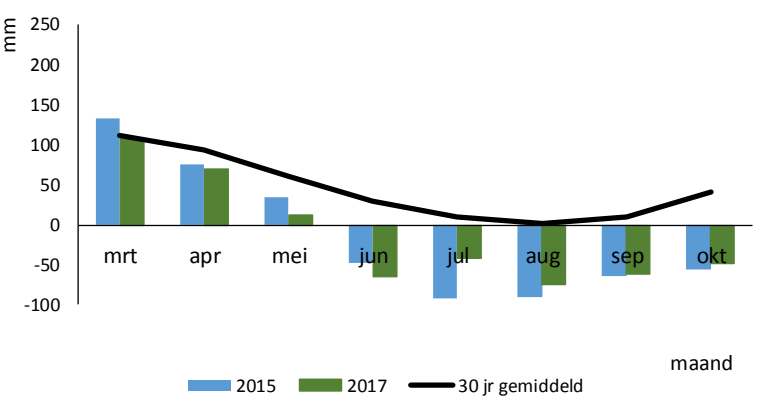

Deelen, cumulatief neerslagoverschot

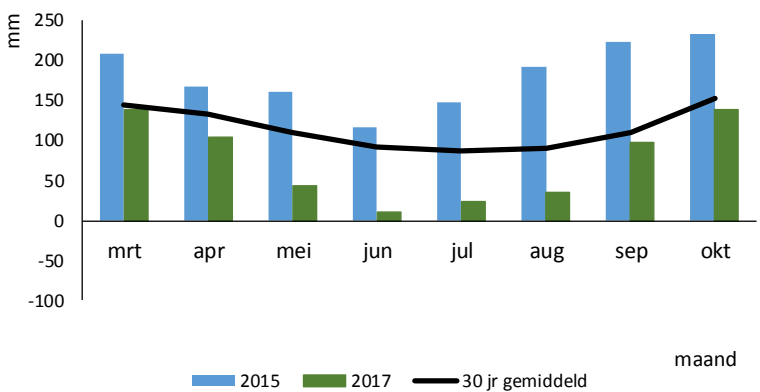

Figuur 2 Gemiddelde etmal temperatur per maand en cumulatief neerslagoverschot (neerslag minus referentie gewasverdamping) aan het eind van de maand gedurende het groeiseizoen en gemiddeld over dertig jaar op het dichtstbijzijnde KNMI-weerstation voor de proeflocaties in de proefjaren. KNMI-station Eelde voor Marwijksoord, Eindhoven voor Vredepeel en Deelen voor Wageningen.

Hiermee is een beeld gegeven van hoe de vochtvoorziening en de temperatuur was in vergelijking met het veeljarig gemiddelde op de locaties. De gegevens zijn afkomstig van het dichtst bij gelegen KNMIweerstation. Voor Marwijksoord is dat Eelde, voor Vredepeel is dat Eindhoven en voor Wageningen is dat Deelen. Alleen de jaren waarin de proeven geslaagd zijn, zijn weergegeven. In bijlage 1 is een gedetailleerd overzicht van de weersomstandigheden per jaar en per locatie opgenomen.

De gemiddelde etmaaltemperatuur in 2015 was op alle locaties in de eerste helft van het groeiseizoen vergelijkbaar met normaal (30-jarig gemiddelde), en in september en oktober lager dan normaal. In 2016 was het op weerstation Eelde in september warmer dan normaal. In 2017 was het op weerstation Eindhoven en Deelen in mei en juni, en in oktober warmer dan normaal. Het neerslagoverschot was in 2015 op weerstation Eelde en Deelen vooral in de tweede helft van het groeiseizoen hoger dan normaal en op weerstation Eindhoven lager dan normaal. In 2016 en 2017 was het neerslagoverschot op alle drie de weerstations lager dan normaal. Op weerstation Eindhoven is het 30 -jarig gemiddelde neerslagoverschot aanmerkelijk lager dan op de beide andere weerstations. 


\section{Resultaten detailproeven}

\subsection{Basisresultaten drogestofopbrengsten}

De opbrengsten van de individuele objecten zijn weergegeven in bijlage 3. In deze paragraaf worden de opbrengsten samengevat en in samenhang met de objecten gepresenteerd.

Tabel 9 geeft de gemiddelde opbrengsten per locatie per jaar en overall.

Tabel 9 Gemiddelde drogestofopbrengsten per jaar per locatie, $k g$ ds/ha.

\begin{tabular}{lllll} 
Locatie/Oogstjaar & $\mathbf{2 0 1 5}$ & 2016 & 2017 & Gem. locatie \\
Marwijksoord & 14874 & 20234 & 23101 & 17554 \\
\hline Vredepeel & 20710 & & 20518 & 21905 \\
\hline Wageningen & 16558 & $13911^{1)}$ & $\mathbf{2 1 8 0 9}$ & $\mathbf{1 8 9 1 5}$ \\
\hline Gemiddeld & $\mathbf{1 7 3 8 1}$ & $\mathbf{1 8 1 2 6}$ & $\mathbf{2 1 2}$ \\
\hline
\end{tabular}

1) Deze lage opbrengst is veroorzaakt door de onweersbuien in juni 2016: gegevens zijn niet meegenomen in de analyse van de detailproeven

Binnen een locatie zijn grote verschillen tussen jaren waargenomen. In 2015 was voor alle locaties de drogestofopbrengst het laagst, als het mislukte proefveld van Wageningen 2016 buiten beschouwing gelaten wordt. In 2017 werden de hoogste opbrengsten gehaald. Gemiddeld genomen zijn de opbrengsten op de proefvelden goed te noemen en geven een goede afspiegeling van de praktijk in vergelijking met de resultaten van de praktijkpercelen in de mini-proeven (hfst 4).

In tabel 10 zijn de opbrengstgegevens per mestsoort (kunstmest of combinatie kunstmest met drijfmest) en per toedieningsmethodiek (breedwerpig/volvelds of in de rij) weergegeven.

Tabel 10 Gemiddelde drogestofopbrengsten bij verschillende meststoffen (kunstmest/drijfmest) en toedieningsmethoden, $\mathrm{kg}$ ds/ha.

\begin{tabular}{|c|c|c|c|c|c|c|c|c|c|}
\hline \multirow{2}{*}{$\begin{array}{l}\text { Locatie, } \\
\text { proefjaar } \\
\text { Objecten }\end{array}$} & & \multicolumn{2}{|c|}{ Marwijksoord } & \multicolumn{2}{|c|}{ Vredepeel } & \multicolumn{2}{|c|}{ Wageningen } & \multicolumn{2}{|c|}{ Gemiddelden } \\
\hline & $\begin{array}{l}\mathrm{N} \\
\text { niveau* } \\
\text { kg N/ha }\end{array}$ & 2015 & 2016 & 2015 & 2017 & 2015 & 2017 & $\begin{array}{l}\text { Alle } \\
\text { jaren }\end{array}$ & $\begin{array}{l}2^{e} \\
\text { proef- } \\
\text { jaar } \\
(2016 / \\
2017)\end{array}$ \\
\hline Geen K & 100 & & 19647 & & 23451 & & 20077 & & 21058 \\
\hline Geen K & 200 & 14964 & 19968 & 19790 & 22793 & 17147 & 20250 & 19152 & 21004 \\
\hline $\begin{array}{l}\text { Kunstm K } \\
\text { volv }\end{array}$ & 100 & & 19473 & & 23057 & & 19577 & & 20702 \\
\hline Drijfm volv & 200 & 14893 & 20438 & 20649 & 23292 & 16347 & & 19420 & \\
\hline Drijfm rij & 200 & 14860 & 20593 & 20588 & 22702 & 15981 & 20515 & 19207 & \\
\hline $\begin{array}{l}\text { Vark drijfm } \\
\text { rij** }\end{array}$ & 200 & & & & & & 20899 & & \\
\hline
\end{tabular}

Kunstm $=$ kunstmest, volv=volvelds, rij=rijenbemesting, drijfm=drijfmest, vark=varken

$* \mathrm{~N}$-niveau in $\mathrm{kg} \mathrm{N}$ werkzaam per ha

**op locatie Wageningen drijfmest volvelds is per abuis varkensmest met rijenbemesting toegediend. $\mathrm{N}$-bemesting is daarop aangepast 
Opvallend is dat op de objecten die met $100 \mathrm{~kg} \mathrm{~N} /$ ha zijn bemest (vergelijking 100 en $200 \mathrm{~N} / \mathrm{ha}$ kunstmestobjecten) zonder kunstmest $\mathrm{K}$ de gemiddelde opbrengst vergelijkbaar was, en met kunstmest $\mathrm{K}$ slechts $600 \mathrm{~kg}$ ds/ha lager was in vergelijking met de objecten met $200 \mathrm{~kg} \mathrm{~N} / \mathrm{ha}$. De vorm waarin de mest is toegediend (kunstmest of drijfmest) heeft nauwelijks invloed gehad op de drogestofopbrengst. Gemiddeld heeft rijenbemesting met kunstmest een licht hogere opbrengst, voornamelijk doordat op Vredepeel in 2015 de drogestofopbrengst bij rijenbemesting ca. $500 \mathrm{~kg}$ ds per ha hoger was. Gemiddeld was de drogestofopbrengst bij drijfmest rijenbemesting wat lager dan bij volveldse toediening, voornamelijk doordat op Vredepeel in 2017 de opbrengst bij drijfmest rijenbemesting ca. $600 \mathrm{~kg}$ per ha lager was.

In figuur 3 is de opbrengst per locatie weergegeven tegen de totale kaligift uit dierlijke mest en kunstmest. Het zijn gemiddelden van de verschillende jaren. Mestsoorten (kunstmest en drijfmest) en toedieningstechnieken (rij en volvelds) zijn onderscheiden. De data van Wageningen uit 2016 zijn buiten beschouwing gelaten.

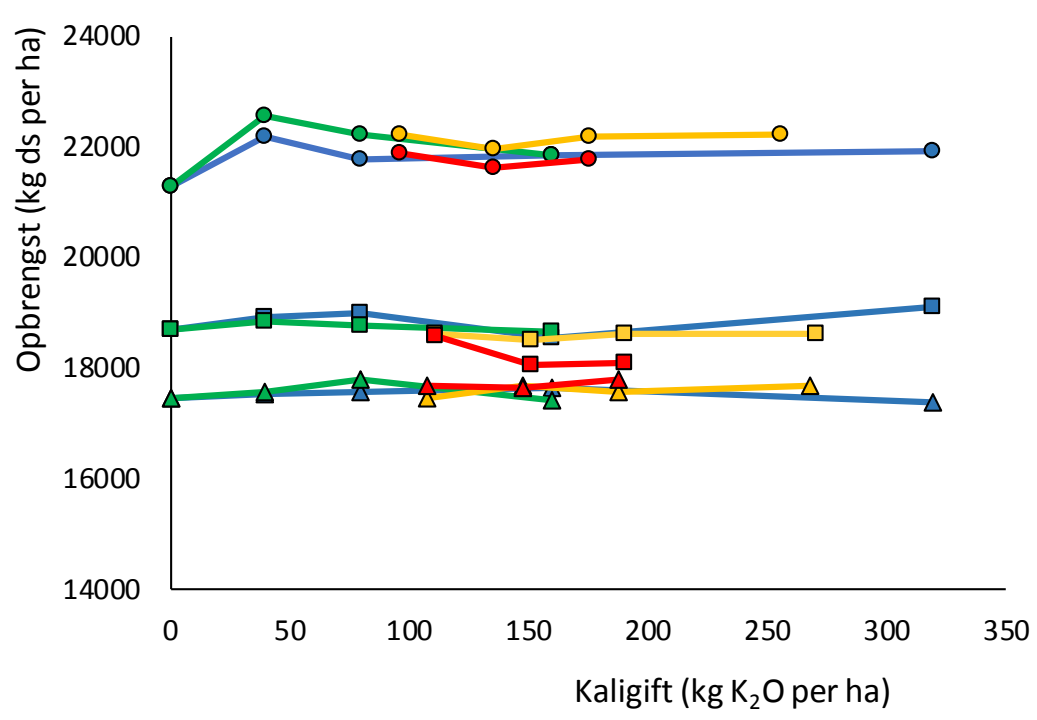

blauw: kunstmest kali volvelds, groen: kunstmest kali in de rij, geel: rundveedrijfmest volvelds, op locatie Wageningen varkensmest in de rij, rood: rundvee drijfmest in de rij

O: Vredepeel

$\Delta$ : Marwijksoord

$\square$ : Wageningen

Figuur 3 Relatie kaligift en droge stofopbrengst op drie proeflocaties, gemiddeld over twee proefjaren.

Uit het overall beeld in figuur 3 lijkt er geen relatie te zijn tussen de kaligift en de drogestofopbrengst van mais. De locatieverschillen zijn goed te zien: Vredepeel geeft de hoogste opbrengsten, Marwijksoord de laagste. Er is geen sprake van een interactie effect tussen kaligift en locatie. In de statistische analyse word nagegaan of en zo ja wanneer er een effect optreedt van de kalibemesting.

\subsection{Basisresultaten K-opbrengsten}

Naast de drogestofopbrengst is ook de K-opbrengst bepaald. De K-opbrengst is berekend door Kgehalte (in de drogestof) en drogestofopbrengst te vermenigvuldigen.

In tabel 11 zijn de gemiddelde $\mathrm{K}$-opbrengsten ( $\mathrm{kg} \mathrm{K} / \mathrm{ha}$ ) per jaar en per locatie weergegeven (gemiddeld over alle bemestingen, mestsoorten en toedieningswijze) met daar achter tussen haakjes de gemiddelde $\mathrm{K}$-gehalten ( $\mathrm{g} / \mathrm{kg}$ ds). Net als voor de drogestofopbrengsten laten de K-opbrengsten ook grote verschillen tussen de jaren zien, maar ook tussen de locaties. Locatie Vredepeel (zand) haalt de hoogste $\mathrm{K}$-opbrengst, corresponderend met de hoogste drogestofopbrengst op deze locatie. Op locatie Wageningen (klei) waren de K-gehalten het laagst en de drogestofopbrengst licht hoger dan op Marwijksoord, waardoor Wageningen de laagste K-opbrengst heeft gerealiseerd. Gemiddeld over de locaties bedroeg de K-opbrengst $118 \mathrm{~kg} \mathrm{~K} / \mathrm{ha}$. Dit komt overeen met $226 \mathrm{~kg} \mathrm{~K}$ O/ha. 
Tabel 11 Gemiddelde K-opbrengsten en K-gehalten (tussen haakjes) per jaar per locatie, $\mathrm{kg} \mathrm{K/ha}$ (en $g \mathrm{~K} / \mathrm{kg} \mathrm{ds}$ ).

\begin{tabular}{lllll} 
Locatie/Oogstjaar & 2015 & 2016 & 2017 & Gem. locatie \\
Marwijksoord & $166(11.2)$ & $198(9.8)$ & $228(9.9)$ & $182(10.5)$ \\
\hline Vredepeel & $225(10.9)$ & & $182(8.9)$ & $226(10.4)$ \\
\hline Wageningen & $128(7.8)$ & & $\mathbf{2 0 5}(\mathbf{9 . 4 )}$ & $155(8.3)$ \\
\hline Gemiddeld & $\mathbf{1 7 3 ( 1 0 . 0 )}$ & $\mathbf{1 9 8 ( 9 . 8 )}$ & $\mathbf{1 8 8}(\mathbf{9 . 7})$ \\
\hline
\end{tabular}

In tabel 12 is het effect van kali uit kunstmest en drijfmest en het effect van de toedieningswijze op $\mathrm{K}$-opbrengst en $\mathrm{K}$-gehalte weergegeven. Het effect van de toedieningsmethode (volvelds vs rij) op zowel de K-opbrengst als het K-gehalte is klein. Het object zonder kali-bemesting (combinatie GeenGeen) geeft de laagste kaliopbrengst en ook het laagste kaligehalte.

Tabel 12 Gemiddelde K-opbrengsten en K-gehalten (tussen haakjes) bij verschillende meststoffen (kunstmest/drijfmest) en toedieningsmethoden, $\mathrm{kg} d \mathrm{~s} / \mathrm{ha}$ (en $\mathrm{kg} \mathrm{K} / \mathrm{ha}$ ).

\begin{tabular}{|c|c|c|c|c|}
\hline \multicolumn{2}{|c|}{ Kaligift kunstmest } & \multicolumn{3}{|l|}{ Drijfmest } \\
\hline Volvelds & $187(9.5)$ & $195(10.2)$ & $202(10.5)$ & $193(9.9)$ \\
\hline Rijenbemesting & $181(9.3)$ & $177(10.3)^{*}$ & $198(10.5)$ & $186(9.8)$ \\
\hline
\end{tabular}

* betreffen resultaten van alleen het jaar 2015

** Exclusief locatie Wageningen 2017

De relatie K-opbrengst en de totale gift met kali (kunstmest + dierlijke mest) is weergegeven in figuur 4. De figuur laat zien dat op alle drie de locaties sprake is van een positief effect van de kalibemesting op de K-opbrengst van snijmais, het sterkst op de locatie Vredepeel, op de locaties Marwijksoord en Wageningen is dit effect in absolute zin kleiner.

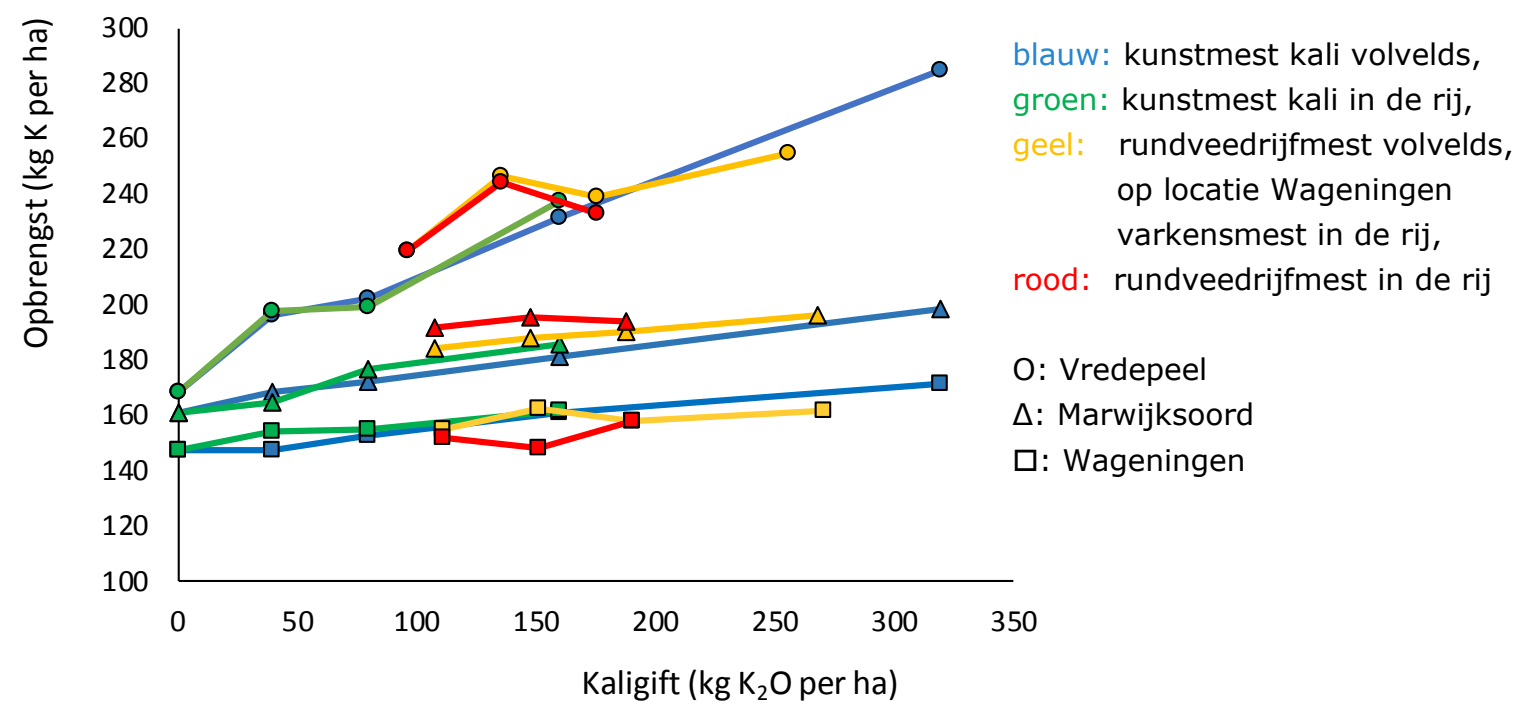

Figuur 4 Relatie kaligift en K-opbrengst (mais) op 3 locaties, gemiddeld over twee proefjaren. 


\subsection{Statistische analyse van de opbrengsten detailproeven}

In tabel 13 is weergegeven in hoeveel van de 6 locatie-jaar combinaties de getoetste factoren en interacties significant zijn voor de onderzochte kenmerken en of significante effecten positief of negatief waren.

De voederwaardebepalingen VEM, DVE, OEB, Structuur Waarde (SW), Ruw Eiwit (RE), Neutral Detergent Fibre (NDF), cel wand verteerbaarheid (CW vert) en zetmeel zijn alleen bepaald op de objecten met kunstmest en zijn op de drijfmestobjecten niet van toepassing (nvt) in de analyse. De groene vakken duiden aan dat de factor op 3 of meer locatie-jaar combinaties significant is, de oranje vakken op 1 of 2 locatie-jaar combinaties. In de oranje vakken is aangegeven op welke locatiejaar combinatie er significantie was.

Tabel 13 Positief of negatief significant effect op (tussen haakjes op welk aantal) Locatie-jaar combinaties, voor de getoetste kenmerken.

\begin{tabular}{|c|c|c|c|c|c|c|c|c|c|c|c|c|}
\hline & Kenmerk: & Dsop & Vsop & Ds $\%$ & Kgeh & Kop & DVE & OEB & RE & CWv & $\mathrm{Zm}$ & $\begin{array}{l}\text { VEM, } \\
\text { SW, } \\
\text { NDF }\end{array}$ \\
\hline & Model factor & & & & & & & & & & & \\
\hline$A$ & $\begin{array}{l}\text { Basisniveau per } \\
\text { Locatie-jaar combi } \\
\text { tov } 0\end{array}$ & $+(6)$ & $+(6)$ & $+(6)$ & $+(6)$ & $+(6)$ & $+(6)$ & $+(6)$ & $+(6)$ & $+(6)$ & $+(6)$ & $+(6)$ \\
\hline B & $\begin{array}{l}\text { Drijfmest volvelds } \\
\text { tov basis }\end{array}$ & $\begin{array}{l}-(1) \\
W^{\prime} 15\end{array}$ & $+(4)$ & $-(5)$ & $+(5)$ & $+(4)$ & nvt & nvt & nvt & nvt & nvt & nvt \\
\hline C & $\begin{array}{l}\text { Rijenbemesting } \\
\text { drijfmest } \\
\text { tov volvelds org } \\
\text { mest }\end{array}$ & $\begin{array}{l}-(1) \\
V^{\prime} 17\end{array}$ & $\begin{array}{l}-(1) \\
V^{\prime} 15\end{array}$ & 0 & $\begin{array}{l}+(1) \\
M^{\prime} 15\end{array}$ & 0 & nvt & nvt & nvt & nvt & nvt & nvt \\
\hline$D$ & $\begin{array}{l}\text { Stikstofniveau } \\
100 \mathrm{~kg} \mathrm{~N} / \mathrm{ha} \text { tov } 200 \\
\mathrm{~kg} \mathrm{~N} / \mathrm{ha}\end{array}$ & $\begin{array}{l}-(2) \\
M^{\prime} 16 \\
W^{\prime} 17\end{array}$ & $\begin{array}{l}-(1) \\
W^{\prime} 17\end{array}$ & 0 & 0 & 0 & 0 & 0 & $\begin{array}{l}-(2) \\
V^{\prime} 17 \\
W^{\prime} 17\end{array}$ & 0 & 0 & 0 \\
\hline$E$ & $\begin{array}{l}\text { Kali kunstmest } \\
\text { volvelds tov geen } \\
\text { kali kunstmest }\end{array}$ & 0 & $+(5)$ & $-(5)$ & $+(5)$ & $+(6)$ & $\begin{array}{l}+(1) \\
W^{\prime} 15\end{array}$ & $-(3)$ & $\begin{array}{l}-(1) \\
M^{\prime} 16\end{array}$ & $\begin{array}{l}-(1) \\
V^{\prime} 17\end{array}$ & $-(3)$ & 0 \\
\hline $\mathrm{F}$ & $\begin{array}{l}\text { Kali kunstmest } \\
\text { rijenbemesting tov } \\
\text { volvelds kunstmest }\end{array}$ & 0 & 0 & $\begin{array}{l}-(1) \\
V^{\prime} 17\end{array}$ & $\begin{array}{l}+(1) \\
V^{\prime} 17\end{array}$ & $\begin{array}{l}+(1) \\
V^{\prime} 17\end{array}$ & 0 & 0 & 0 & 0 & 0 & 0 \\
\hline G & $\begin{array}{l}\text { Kali kunstmest bij } \\
\text { drijfmest tov zonder } \\
\text { org mest }\end{array}$ & 0 & 0 & 0 & 0 & 0 & nvt & nvt & nvt & nvt & nvt & nvt \\
\hline
\end{tabular}

Loc.jr = Locatie.oogstjaar

Dsop= drogestofopbrengst; Vsop= vers opbrengst; Ds\%= drogestofpercentage; Kgeh= K-gehalte;

Kop= Kaliopbrengst;

Voederwaarde kenmerken: VEM= VoederEenheid Melk, maat voor energie inhoud; DVE= Darm Verteerbaar Eiwit; OEB= Onbestendig Eiwit Balans; SW= Structuur Waarde; RE= Ruw Eiwit; NDF= Neutral Detergent Fibre; $\mathrm{CWv}=\mathrm{Cel}$ Wand verteerbaarheid; $\mathrm{Zm}=$ Zetmeel

NB: voederwaarde kenmerken zijn niet bepaald op drijfmestobjecten, daar niet van toepassing (nvt)

$X=$ significant effect op 3 of meer locaties

$\mathrm{X}=$ significant effect op 1 of 2 locaties

0 = geen significante effecten

Indien 1 of 2 locatie-jaar combinaties significant: V=Vredepeel (zand), W=Wageningen (klei), $M=$ Marwijksoord (zand); ' $x x=$ jaartal 20xx

- K-bemesting (factor $\mathrm{E}$ ) had geen effect op drogestofopbrengst. K-bemesting had wel een positief effect op vers-opbrengst, het $\mathrm{K}$-gehalte en de $\mathrm{K}$-opbrengst en een negatief effect op drogestofpercentage. 
- Er waren verschillen tussen de locatie-jaar combinaties (factor A) in alle kenmerken voor opbrengst en gehalten.

- Het toedienen van volvelds drijfmest (factor B) had vrijwel geen effect op drogestofopbrengst en een positief effect op vers-opbrengst, K-gehalte en K-opbrengst en een negatief effect op drogestofgehalte. Alleen op locatie Wageningen in 2015 was er een negatief effect van drijfmest op de drogestofopbrengst.

- De plaatsing van drijfmest in de rij (factor $\mathrm{C}$ ) had een gelijk effect als volvelds drijfmest toedienen.

- $\quad$ Het verlagen van het stikstofniveau (factor D) van 200 naar $100 \mathrm{~kg} \mathrm{~N} / \mathrm{ha}$ (in 2016 en 2017 uitgevoerd) had op de twee locaties een negatief effect op drogestofopbrengst van ca. $700 \mathrm{~kg}$ $\mathrm{ds} / \mathrm{ha}$ en op ruw eiwitgehalte van 2 tot $3 \mathrm{~g}$ re/ $\mathrm{kg}$ ds.

- $\quad$ Op de helft van de locatie-jaar combinaties was er een negatief effect van K-bemesting op OEB en zetmeel (factor $\mathrm{E}$ ).

- $\quad$ Rijenbemesting met K-kunstmest ten opzichte van volvelds (factor $F$ ) had alleen effect op Vredepeel in 2017: de effecten van de K-bemesting op K-gehalte, -opbrengst, vers-opbrengst en drogestofgehalte werden daar versterkt wanneer rijenbemesting werd toegepast.

- De plaatsing van drijfmest (factor $\mathrm{G}$ ) had geen effect op de grootte van de respons op de $\mathrm{K}$ bemesting. Voor Wageningen 2017 gold dat zowel varkensmest in de rij als rundveemest in de rij geen effect hadden op de respons op de K-bemesting.

- $\quad$ Uit deze analyse is niet af te leiden of de $\mathrm{K}$ uit drijfmest dezelfde werking heeft als de $\mathrm{K}$ uit kunstmest. Daarvoor is een aparte analyse uitgevoerd die is weer gegeven in bijlage 4 . Daaruit bleek dat de respons van $\mathrm{K}$-gehalte en $\mathrm{K}$-opbrengst op de $\mathrm{K}$ uit drijfmest vrijwel altijd gelijk was aan de respons op kunstmest. Uitzondering was locatie Vredepeel in 2017, daar was een grotere respons op K uit drijfmest dan uit kunstmest. De K-werkingscoëfficiënt van drijfmest was dus in alle gevallen minimaal $100 \%$ en slechts in 1 van de 6 situaties hoger.

\section{Kwantificering effecten}

Voor beoordeling van effecten is niet alleen nodig om te weten of factoren significant zijn maar ook om de effecten te kwantificeren. Bij het vaststellen van een bemestingsadvies is het van belang om na te gaan hoe groot de onttrekking van een element is. Als een bemestingsadvies daar ver onder zit, mag verwacht worden dat op korte of lange termijn de bodemvoorraad van het element afneemt. Bij een hoge bodemvoorraad is dat geen probleem en soms zelfs gewenst. Bij een voldoende en lagere bodemvoorraad kan de afname van de voorraad de opname zover belemmeren dat de gewasopbrengsten gereduceerd worden. Dat is niet gewenst.

Hoe groot de onttrekking aan $\mathrm{K}_{2} \mathrm{O}$ is, kan berekend worden op basis van de parameterschattingen uit de statistische analyse. In bijlage 4 staan de parameterschattingen voor de modelfactoren, zoals ze berekend zijn in de statistische analyse. In tabel 14 wordt met de modelfactoren voor de $\mathrm{K}_{2} \mathrm{O}$ opbrengst en een K-bemesting de $\mathrm{K}$-opbrengst berekend. Als voorbeeld is dit voor de 6 locatie-jaar combinaties uit de proef berekend bij een volveldse kunstmest-kali gift van 200 en $300 \mathrm{~kg} \mathrm{~K} \mathrm{~K}_{2} \mathrm{O}$ per ha. Daarbij zijn de factoren $\mathrm{B}$ en $\mathrm{F} 0$.

In 4 van de 6 locatie-jaar combinaties is bij een gift van $200 \mathrm{~kg} \mathrm{~K}_{2} \mathrm{O}$ per ha de onttrekking (= de $\mathrm{K}_{2} \mathrm{O}$ opbrengst) hoger dan de gift en zal op deze locaties bij deze gift de K-voorraad in de bodem worden aangesproken en de kali-toestand dalen in de loop van de jaren. Bij een gift van $300 \mathrm{~kg} \mathrm{~K}_{2} \mathrm{O}$ per ha zou alleen op Vredepeel in 2015 de gift kleiner zijn dan de onttrekking en de kali-toestand dalen. 
Tabel 14 Kwantificering kalionttrekking bij een bemesting met volvelds kunstmest van 200 en 300 kg $\mathrm{K}_{2} \mathrm{O} / \mathrm{ha}$.

\begin{tabular}{|c|c|c|c|c|c|c|c|}
\hline & \multirow{4}{*}{$\begin{array}{l}\text { Model } \\
\text { factor }\end{array}$} & \multicolumn{6}{|l|}{ Loc.jr } \\
\hline & & & & & & & \\
\hline & & MW & MW & VP & VP & $\mathrm{Wg}$ & $\mathrm{Wg}$ \\
\hline & & 15 & 16 & 15 & 17 & 15 & 17 \\
\hline A & Niveau & 151 & 175 & 171 & 188 & 120 & 175 \\
\hline \multirow[t]{2}{*}{ B } & Org mst vlv & 16,9 & 27,6 & 37,9 & 43,8 & 5,7 & \\
\hline & Vark mst rij & & & & & & 2,9 \\
\hline$E$ & $\mathrm{Km}$ vlv & 0,080 & 0,129 & 0,387 & 0,215 & 0,086 & 0,059 \\
\hline \multirow[t]{7}{*}{$\mathrm{F}$} & $\begin{array}{l}\text { Km rij vs } \\
\text { vlv }\end{array}$ & $-0,0404$ & 0,0746 & $-0,0212$ & 0,152 & $-0,0510$ & 0,0608 \\
\hline & K-opbrengst & $167 \mathrm{~K}=$ & $201 \mathrm{~K}=$ & $248 \mathrm{~K}=$ & $231 \mathrm{~K}=$ & $137 \mathrm{~K}=$ & $187 \mathrm{~K}=$ \\
\hline & bij 200 kg & $200 \mathrm{~K}_{2} \mathrm{O}$ & $241 \mathrm{~K}_{2} \mathrm{O}$ & $298 \mathrm{~K}_{2} \mathrm{O}$ & $277 \mathrm{~K}_{2} \mathrm{O}$ & $165 \mathrm{~K}_{2} \mathrm{O}$ & $224 \mathrm{~K}_{2} \mathrm{O}$ \\
\hline & $\mathrm{K}_{2} \mathrm{O} / \mathrm{ha}$ & & & & & & \\
\hline & K-opbrengst & $175 \mathrm{~K}=$ & $214 \mathrm{~K}=$ & $287 \mathrm{~K}=$ & $253 \mathrm{~K}=$ & $146 \mathrm{~K}=$ & $193 \mathrm{~K}=$ \\
\hline & bij 300 kg & $209 \mathrm{~K}_{2} \mathrm{O}$ & $255 \mathrm{~K}_{2} \mathrm{O}$ & $343 \mathrm{~K}_{2} \mathrm{O}$ & $302 \mathrm{~K}_{2} \mathrm{O}$ & $174 \mathrm{~K}_{2} \mathrm{O}$ & $230 \mathrm{~K}_{2} \mathrm{O}$ \\
\hline & $\mathrm{K}_{2} \mathrm{O} / \mathrm{ha}$ & & & & & & \\
\hline
\end{tabular}

Vet: significante factor. In berekening zijn niet-significante factoren wel meegerekend.

In tabel 15 is dezelfde berekening uitgevoerd voor K-gehalte. De variatie van het K-gehalte is vrij groot, het varieert van 8 tot $12 \mathrm{~g} \mathrm{~K} / \mathrm{kg}$ ds bij een gift met volvelds kunstmest van $200 \mathrm{~kg} \mathrm{~K} \mathrm{~K}_{2} \mathrm{O}$ per ha. Wanneer in de praktijk de $\mathrm{K}$-opbrengst berekend wordt om de $\mathrm{K}$-onttrekking te bepalen, is het gebruiken van een vast $\mathrm{K}$-gehalte mogelijk niet nauwkeurig genoeg. In veel gevallen is er sprake van luxe consumptie van $\mathrm{K}$ waar meeropbrengsten door $\mathrm{K}$-bemesting niet konden worden aangetoond.

Tabel 15 Kwantificering kaligehalte bij een bemesting met volvelds kunstmest van 200 en $300 \mathrm{~kg}$ $\mathrm{K}_{2} \mathrm{O} / \mathrm{ha}$.

\begin{tabular}{|c|c|c|c|c|c|c|c|}
\hline & \multirow[t]{2}{*}{ Model factor } & \multicolumn{6}{|l|}{ Loc.jr } \\
\hline & & 15 & 16 & 15 & 17 & 15 & 17 \\
\hline$A$ & Niveau & 10,00 & 8,80 & 8,12 & 8,13 & 7,04 & 8,67 \\
\hline B & Org mst vlv & 0,93 & 1,07 & 1,90 & 1,89 & 0,73 & \\
\hline$E$ & $\mathrm{Km}$ vlv & 0,0067 & 0,0057 & 0,0191 & 0,0093 & 0,0047 & 0,0025 \\
\hline \multirow[t]{3}{*}{$\mathrm{F}$} & Km rij vs vlv & $-0,0026$ & 0,0028 & 0,0001 & 0,0083 & $-0,0033$ & 0,0026 \\
\hline & K-gehalte bij & 11,3 & 9,9 & 11,9 & 10,0 & 8,0 & 9,2 \\
\hline & $200 \mathrm{~kg} \mathrm{~K}{ }_{2} \mathrm{O} / \mathrm{ha}$ & & & & & & \\
\hline
\end{tabular}

Vet: significante factor. In berekening zijn niet-significante factoren wel meegerekend. 


\section{$4 \quad$ Resultaten miniproeven}

\subsection{Grond- en mestanalyses}

In Tabel 16 zijn de grondanalyseresultaten samengevat. $\mathrm{Er}$ is een ruime variatie in bodemkengetallen. Met betrekking tot het $\mathrm{K}$-gehalte varieert $\mathrm{K}$ in $\mathrm{CaCl}_{2}$-extractie van meer dan 9 tot $400 \mathrm{mg} \mathrm{kg}^{-1} . \mathrm{K}-\mathrm{HCl}$ kent in 2016 eveneens een grote variatie, in 2015 is $\mathrm{K}-\mathrm{HCl}$ niet gemeten. Ook de CEC, lutum en organische stof kennen een ruime variatie. De fosfaattoestand van de percelen bevond zich in het algemeen op een goed niveau. Eén perceel in 2016 kende erg lage P-toestanden. In Figuur 5 is het verschil in $\mathrm{K} \mathrm{CaCl}_{2}$ per locatie tussen perceel 1 en perceel 2 weergegeven. Gemiddeld bedroeg dat verschil 41 . Ongeveer $30 \%$ en $50 \%$ van de grondmonsters had een $\mathrm{K}$-gehalte kleiner dan respectievelijk 50 en 75 mg per kg. Uit Figuur 5 blijkt dat bij de gekozen locaties op de klei(ige)gronden (meer dan $10 \%$ lutum) ook een ruim variatie in K-gehalte aanwezig was; van minder dan 30 tot 150 (en twee extremen boven de 300).

Tabel 16 Overzicht grondanalyseresultaten.

\begin{tabular}{|c|c|c|c|c|c|c|}
\hline \multicolumn{2}{|l|}{ Bodemparameters } & \multicolumn{3}{|l|}{2015} & \multicolumn{2}{|l|}{2016} \\
\hline $\mathrm{N}$-Tot $(\mathrm{mg} / \mathrm{kg})$ & 1100 & 4470 & 1960,5 & 960 & 4620 & 1699,8 \\
\hline $\mathrm{CN}$ & 8 & 20 & 12,7 & 8 & 20 & 13,7 \\
\hline $\operatorname{NLV}(\mathrm{kg} \mathrm{N} \mathrm{ha-1})$ & 40 & 208 & 96,0 & 41 & 212 & 81,7 \\
\hline P-AL (mg P2O5/100 g) & 34 & 154 & 64,8 & 6 & 232 & 62,8 \\
\hline $\mathrm{K}-\mathrm{CaCl}_{2}\left(\mathrm{mg} \mathrm{kg}^{-1}\right)$ & 23 & 168 & 81,0 & 9 & 433 & 80,0 \\
\hline K-getal & 8 & 35 & 19,1 & 1 & 101 & 19,2 \\
\hline $\mathrm{Mg}-\mathrm{CaCl}_{2}\left(\mathrm{mg} \mathrm{kg}^{-1}\right)$ & 35 & 347 & 125,4 & 33 & 365 & 121,1 \\
\hline $\mathrm{Na}-\mathrm{CaCl}_{2}\left(\mathrm{mg} \mathrm{kg}^{-1}\right)$ & 5 & 80 & 15,5 & 6 & 96 & 15,2 \\
\hline $\mathrm{KZK}$ & 0,2 & 6,2 & 1,0 & 0,2 & 6,5 & 0,8 \\
\hline OS (\%) & 2,5 & 8,9 & 4,4 & 1,8 & 9,1 & 3,9 \\
\hline $\mathrm{CEC}\left(\mathrm{mmol}+\mathrm{kg}^{-1}\right)$ & 31 & 365 & 123,7 & 29 & 360 & 101,9 \\
\hline CEC-Bez. (\%) & 76 & 100 & 94,2 & 69 & 100 & 92,8 \\
\hline $\mathrm{pH}-\mathrm{CaCl}_{2}(\%)$ & 4,3 & 6,7 & 5,6 & 4,7 & 6,8 & 5,8 \\
\hline Silt (\%) & 5 & 44 & 19,9 & 1 & 46 & 18,4 \\
\hline Zand (\%) & 10 & 90 & 62,4 & 15 & 92 & 67,6 \\
\hline Lutum (\%) & 1 & 49 & 12,3 & 1 & 47 & 9,5 \\
\hline
\end{tabular}



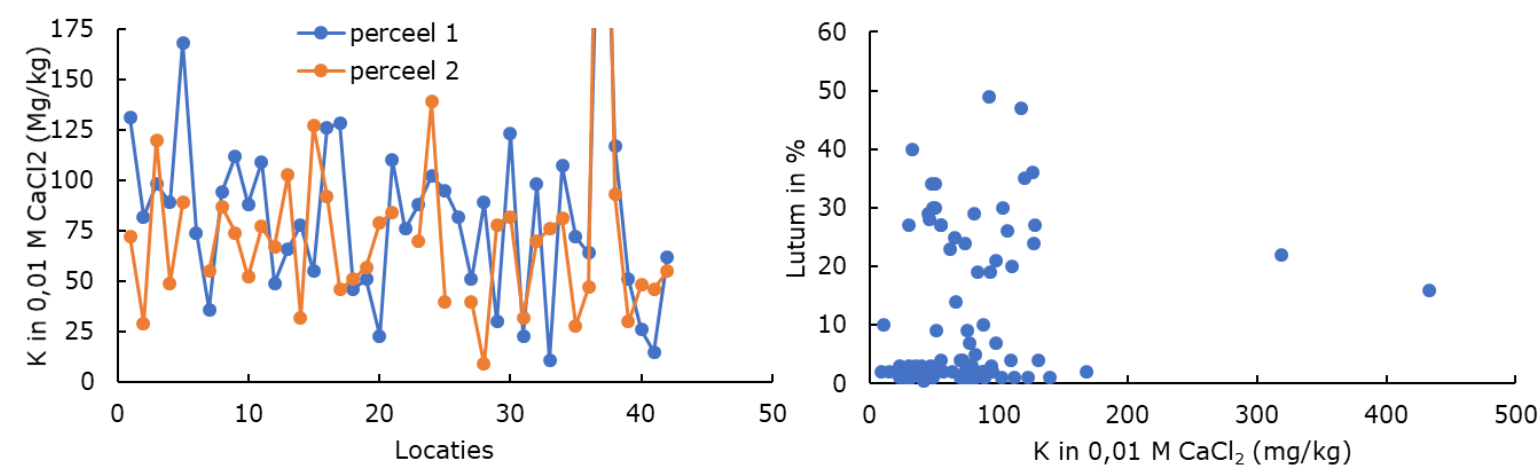

Figuur 5 Het K-gehalte van de bodem van perceel 1 en 2 per locatie in 2015 en 2016 (links) en het $K$-gehalte uitgezet tegen het lutumgehalte van de grondmonsters van 2015 en 2016 (rechts).

$\mathrm{Er}$ is een ruime spreiding in de drogestofopbrengst zoals figuur 6 laat zien. Bij de opbrengsten van rond de 10 ton en lager zijn er enkele percelen met schade. Die zijn in de uiteindelijke analyse achterwege gelaten. De gemiddelde opbrengst bevond zich op een goed niveau met een opbrengst van bijna 19 ton ds ha-1. Het K-gehalte bedroeg gemiddeld ruim 10,5 g k kg-1 ds, waarbij zo'n $15 \%$ van de gevallen er minder dan $8 \mathrm{~g} \mathrm{~K} \mathrm{~kg}^{-1}$ ds aanwezig was. Gegeven de variatie in drogestofopbrengsten en $\mathrm{K}$-gehalte is dus ook een grote bandbreedte in $\mathrm{K}(2 \mathrm{O})$-opname. Gemiddeld werd er respectievelijk $200 \mathrm{~kg} \mathrm{~K} \approx 240 \mathrm{~kg} \mathrm{~K}_{2} \mathrm{O} \mathrm{ha}{ }^{-1}$ opgenomen. Een belangrijk deel daarvan is het gevolg van luxe consumptie, $\mathrm{K}$-gehaltes van boven de $10 \mathrm{~g} \mathrm{~K} \mathrm{~kg}^{-1} \mathrm{ds}$ zijn niet nodig voor een optimale maïsproductie. Op basis van figuur 7 lijkt het waarschijnlijk dat het kritisch K-gehalte nog lager is.
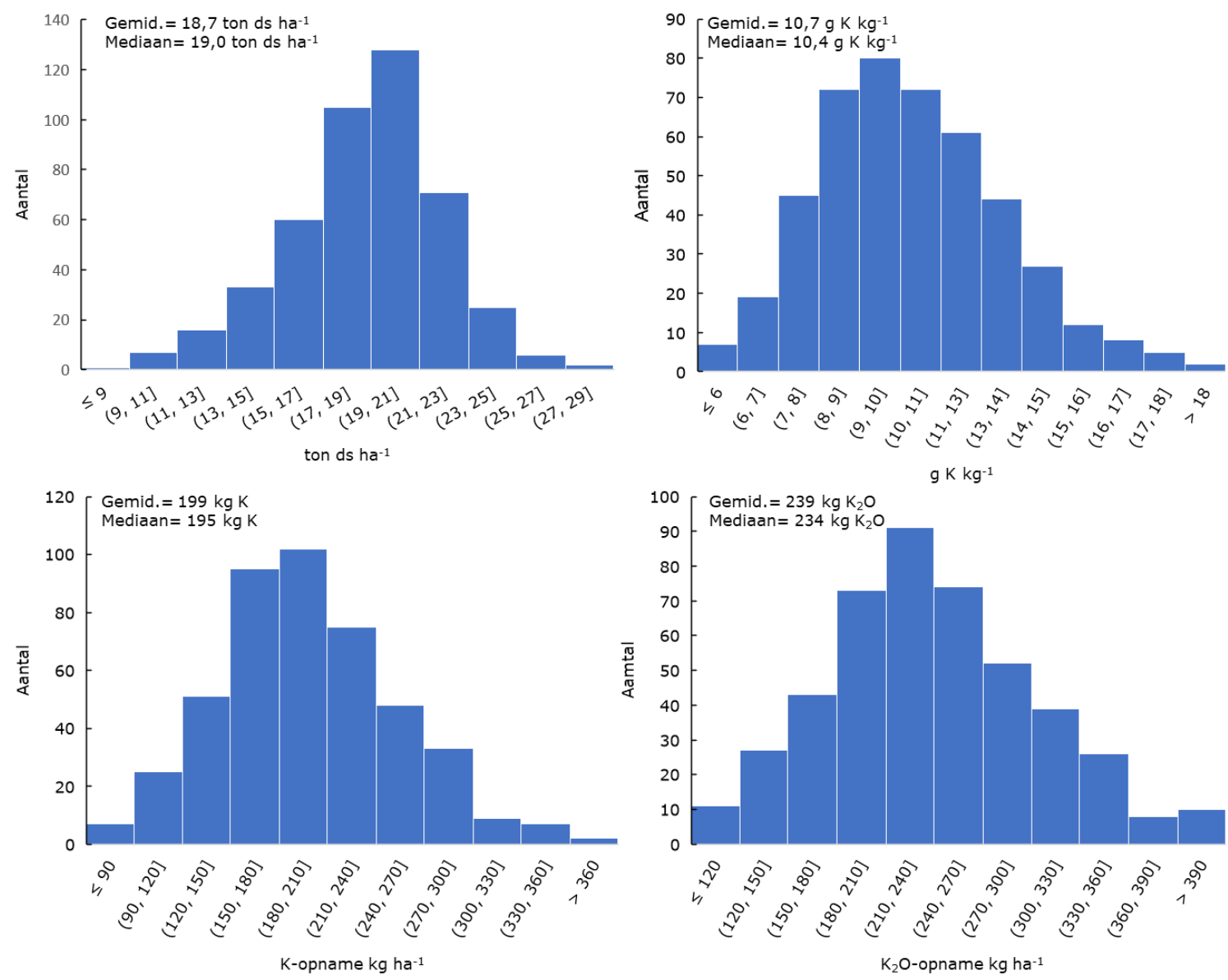

Figuur 6 De frequentieverdeling van de drogestofopbrengsten, het $\mathrm{K}$-gehalte, de $\mathrm{K}$ - en $\mathrm{K}_{2} \mathrm{O}$ opname van de individuele maisveldjes in de Miniproef van 2015 en 2016. 

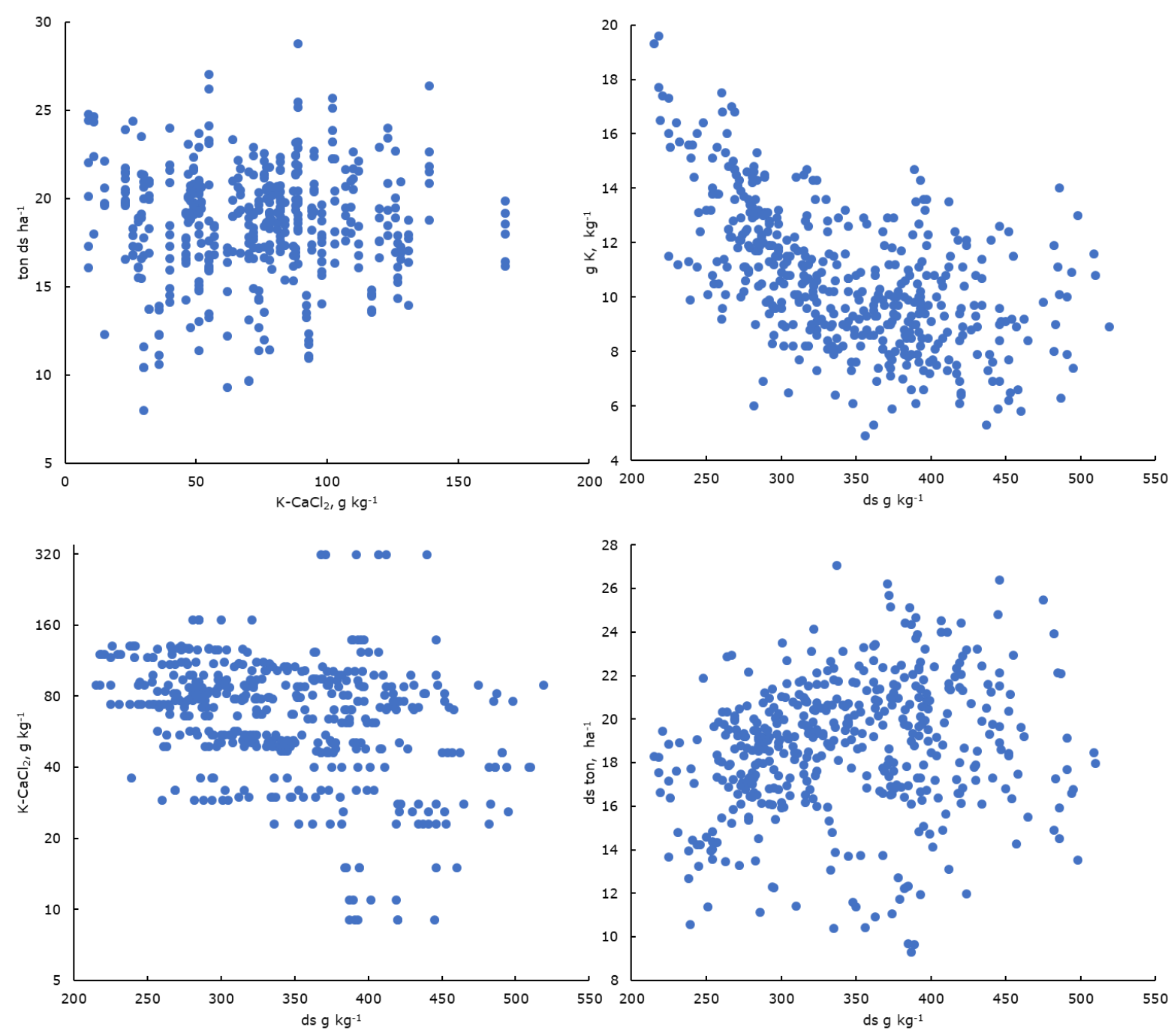

Figuur 7 De relatie $K-\mathrm{CaCl}_{2}$ en de drogestofopbrengst plus de relatie tussen het drogestofpercentage en $\mathrm{K}-\mathrm{CaCl}$, drogestofopbrengst, en $\mathrm{K}$-gehalte in de drogestof in de Miniproeven van 2015 en 2016.

De gekozen percelen verschillen sterk in $\mathrm{K}-\mathrm{CaCl}_{2}$ waarden. Toch lijkt er geen sterk verband te zijn tussen deze waarde en de drogestofopbrengst. Zelfs bij heel lage waarden kan met bemesting een vergelijkbare opbrengst worden gerealiseerd als bij een hoge $\mathrm{K}-\mathrm{CaCl}_{2}$ waarde. Verder is opvallend dat het $\mathrm{K}$-gehalte sterk samenhangt met het drogestofgehalte van de mais. Hoe hoger dit gehalte des te lager is het $\mathrm{K}$-gehalte. Een mogelijk fysiologische verklaring zou kunnen zijn dat bij veel $\mathrm{K}$ in de plant, de plant meer water moet opnemen om de osmotische potentiaal niet te hoog te laten worden.

Daarentegen lijkt de drogestofopbrengst eerder te stijgen dan te dalen bij een toenemend drogestofgehalte. Een laag $\mathrm{K}-\mathrm{CaCl}_{2}$ waarde van de bodem lijkt samen te gaan met een hoog drogestofgehalte (Figuur 7, linksonder). Op basis van de visuele weergave in figuur 7 lijkt een lage toestand eerder een gunstige dan een slecht uitgangspositie te geven voor een hoge opbrengst.

\subsection{Basisresultaten opbrengst, $\mathrm{K}$-gehalte en -opname}

Op een aantal locaties lukte het niet om drijfmest toe te dienen omdat de grond te weinig draagkracht had. Deels zijn daarvoor extra kalitrappen aangelegd. De gemiddelde drogestofopbrengst bevond zich op een goed niveau met bijna 19 ton ds ha-1 (Tabel 17). De opbrengstniveaus zijn in beide jaren vergelijkbaar. In 2015 zijn de verschillen in opbrengst tussen de behandelingen klein. In 2016 lijken deze wat groter te zijn, waarbij OK de laagste opbrengst heeft. De 320K behandelingen van 2016 hebben een lage opbrengst. Deze lagen alle op rivierklei. De $\mathrm{K}$ - en $\mathrm{K}_{2} \mathrm{O}$-opbrengsten bedroegen gemiddeld respectievelijk 210 en $253 \mathrm{~kg} \mathrm{ha}^{-1}$ in 2015 en 187 en $226 \mathrm{~kg} \mathrm{ha}^{-1}$ in 2016 . Het verschil 
tussen geen en $160 \mathrm{~K}_{2} \mathrm{O}$-bemesting was beperkt en bedroeg ongeveer $20 \mathrm{~kg} \mathrm{~K}_{2} \mathrm{O} \mathrm{ha}^{-1}$ in beide jaren. Hoewel de drogestofopbrengst gemiddeld hoger was in 2016 was de $\mathrm{K}_{2} \mathrm{O}$-opname gemiddeld zo'n 25 $\mathrm{kg} \mathrm{K}_{2} \mathrm{O} \mathrm{ha}^{-1}$ lager dan in 2015. De $\mathrm{K}$-gehalten in mais bewegen zich zo rond de $10 \mathrm{~g} \mathrm{~kg}^{-1} \mathrm{ds}$ met ongeveer $1 \mathrm{~g}$ verschil tussen een lage en een hoge K-bemesting.

Figuur 8 laat zien dat er bij een $\mathrm{K}-\mathrm{CaCl}_{2}<50 \mathrm{mg} \mathrm{kg}^{-1}$ sprake is van een opbrengstrespons van ongeveer 1,8 ton $\mathrm{ds} \mathrm{ha}^{-1}$ door $\mathrm{K}$-bemesting ten opzichte van indien er geen $\mathrm{K}$ wordt bemest. Bij $\mathrm{K}$ $\mathrm{CaCl}_{2}=50-79$ is er daarentegen nauwelijks nog sprake van een opbrengstrespons. Verder laat de figuur zien dat met $40 \mathrm{~kg} \mathrm{~K} \mathrm{O} \mathrm{ha}^{-1}$ al de maximale opbrengst wordt gehaald. De behandelingen met dierlijke mest lijken wat achter te blijven, vooral bij $\mathrm{K}-\mathrm{CaCl}_{2}=50-79$. Mogelijk is er structuurschade opgetreden tijdens het toedienen van mest. Uit het rechterdeel van de Figuur 8 blijkt dat bij $\mathrm{K}-\mathrm{CaCl}_{2}<$ 50 met K-gehalte van $8,0-8,5 \mathrm{~g} \mathrm{~kg}^{-1}$ ds al de maximale drogestofopbrengst wordt gerealiseerd. Meer bemesten dan $80 \mathrm{~kg} \mathrm{~K}_{2} \mathrm{O}$ ha-1 $^{-1}$ leidt tot een duidelijke stijging van het $\mathrm{K}$-gehalte. Deze waarde van 8,0$8,5 \mathrm{~g} \mathrm{~kg}^{-1} \mathrm{ds}$ kan gezien worden als een kritisch $\mathrm{K}$-gehalte. Hier wordt verderop op teruggekomen. Verder neemt het $\mathrm{K}$-gehalte sterk toe naarmate het $\mathrm{K}-\mathrm{CaCl}_{2}$-gehalte van de bodem hoger is. De hoogste $\mathrm{K}$-gehalten worden gemeten op de behandelingen met dierlijke mest. Gemiddeld is met de dierlijke mest $248 \mathrm{~K}_{2} \mathrm{O} \mathrm{ha}^{-1}$ toegediend. Dit vertaalt zich in hogere gehalten dan de behandeling met $160 \mathrm{~kg} \mathrm{~K}_{2} \mathrm{O} \mathrm{ha}^{-1}$ toegediend als minerale meststof. Bovenop de dierlijke mest nog $80 \mathrm{~kg} \mathrm{~K}_{2} \mathrm{O} \mathrm{ha}^{-1} \mathrm{geeft}$ nauwelijks nog een verdere stijging van het $\mathrm{K}$-gehalte. $\mathrm{Bij}$ een lage toestand $\left(\mathrm{K}-\mathrm{CaCl}_{2}<50\right)$ en $40-80$ $\mathrm{kg} \mathrm{K}_{2} \mathrm{O} \mathrm{ha}^{-1}$ wordt er bijna $160 \mathrm{~kg} \mathrm{~K}$ (bijna $190 \mathrm{~kg} \mathrm{~K}_{2} \mathrm{O}$ ) ha-1 opgenomen en wordt tegelijkertijd ook de maximale drogestofopbrengst bereikt. Maïs kan dus kennelijk met relatief weinig kalium toe om maximaal te produceren.

Aanvullend zijn de opbrengstgegevens zoals die zijn weergegeven in Figuur 8 en 9 ook statistisch geanalyseerd met REML eveneens uitgesplitst naar 3 groepen van $\mathrm{K}-\mathrm{CaCl}_{2}$ waarden met als toevalsfactor (Jaar.Bedrijf)/Perceelsnaam. Nogmaals is te zien dat bij K-CaCl $2<50 \mathrm{mg} \mathrm{kg}^{-1}$ en geen $\mathrm{K}$-bemesting de opbrengst significant lager is dan met een bemesting van $40 \mathrm{~kg} \mathrm{~K}{ }_{2} \mathrm{O} / \mathrm{ha}$ en hoger. De behandeling met dierlijke mest lijken achter te blijven ten opzichte van K-bemesting met 40,80 of $160 \mathrm{~kg} \mathrm{~K}_{2} \mathrm{O} \mathrm{ha}{ }^{-1}$, vooral $\mathrm{rdm}+0$.

Tabel 17 Drogestofopbrengst, K-gehalte en -opbrengst per behandeling en per jaar.

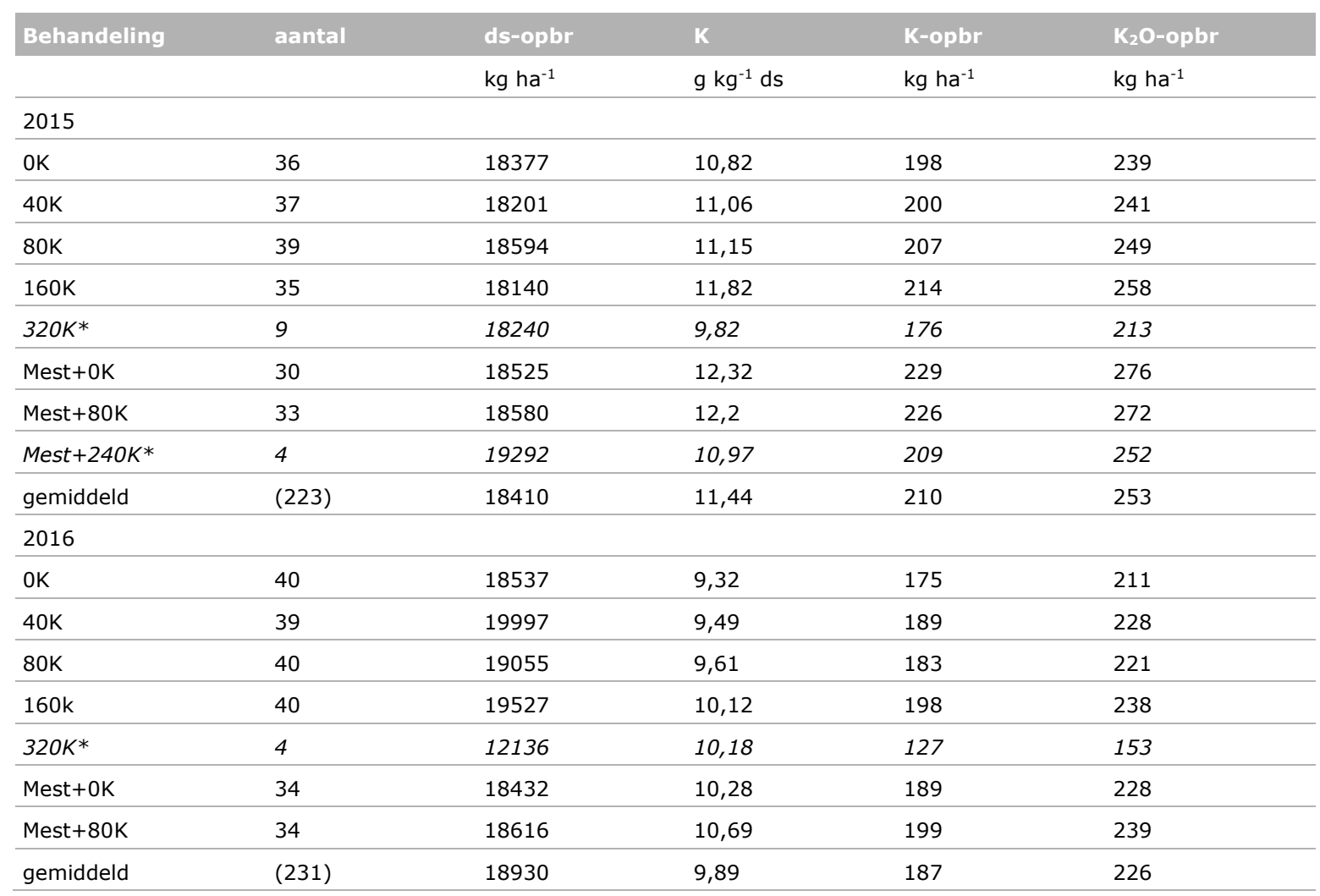

* afwijkende objecten omdat er geen mest kon worden toegediend. 

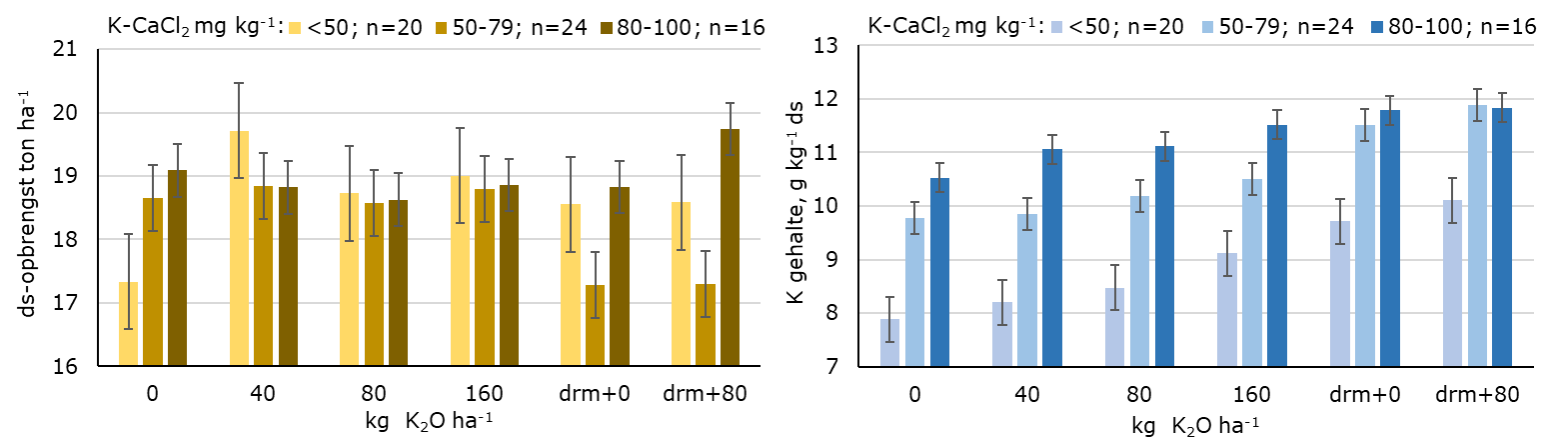

Figuur 8 Drogestofopbrengst (links) en het $K$-gehalte (rechts) uitgesplitst naar de 6 behandelingen en opgedeeld naar 3 groepen van $\mathrm{K}-\mathrm{CaCl}_{2}$ waarden $\left(<50,50-80\right.$ en $80-100 \mathrm{mg} \mathrm{kg}^{-1}$ ).

De K-opname (Figuur 9) varieert sterk, van minder dan 140 tot meer dan $220 \mathrm{~kg} \mathrm{~K} \mathrm{ha}^{-1}$ (162 tot 260 $\mathrm{kg} \mathrm{K}_{2} \mathrm{O} \mathrm{ha}^{-1}$ ).
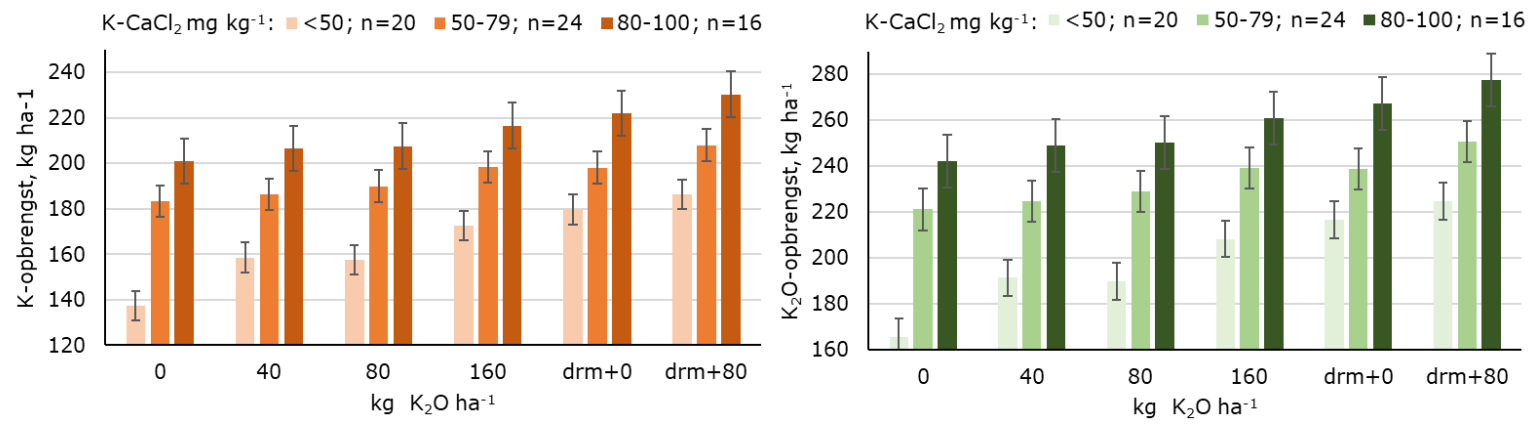

Figuur 9 De $\mathrm{K}$ - (links) en $\mathrm{K}_{2} \mathrm{O}$-opbrengst (rechts) uitgesplitst naar de 6 behandelingen en opgedeeld naar 3 groepen van $\mathrm{K}-\mathrm{CaCl}_{2}$ waarden ( $<50,50-80$ en $\left.80-100 \mathrm{mg} \mathrm{kg}^{-1}\right)$.

Tabel 18 Gemiddelde opbrengst, K-gehalte en $\mathrm{K}_{2} \mathrm{O}$-opname in de miniproeven van 2015 en 2016 bij een indeling in 3 groepen van $\mathrm{K}-\mathrm{CaCl}_{2}$ waarden.

\begin{tabular}{|c|c|c|c|c|c|c|c|c|c|}
\hline \multirow{2}{*}{$\mathrm{kg} \mathrm{K}_{2} \mathrm{O}$ ha $^{-1}$} & \multicolumn{3}{|c|}{$\mathrm{K}-\mathrm{CaCl}_{2}<50 ; \mathrm{n}=20$} & \multicolumn{3}{|c|}{$\mathrm{K}-\mathrm{CaCl}_{2} 50-79 ; \mathrm{n}=24$} & \multicolumn{3}{|c|}{$\mathrm{K}-\mathrm{CaCl}_{2} 80-99 ; \mathrm{n}=16$} \\
\hline & ds & gehalte & opname & ds & gehalte & opname & ds & gehalte & opname \\
\hline & ton ha-1 & $\mathrm{g} \mathrm{kg}^{-1} \mathrm{ds}$ & $\mathrm{kg} \mathrm{K}_{2} \mathrm{O} \mathrm{ha}^{-1}$ & ton $\mathrm{ha}^{-1}$ & $\mathrm{~g} \mathrm{~kg}^{-1} \mathrm{ds}$ & $\mathrm{kg} \mathrm{K}_{2} \mathrm{O} \mathrm{ha}{ }^{-1}$ & ton $\mathrm{ha}^{-1}$ & $\mathrm{~g} \mathrm{~kg}^{-1} \mathrm{ds}$ & $\mathrm{kg} \mathrm{K}_{2} \mathrm{O} \mathrm{ha}{ }^{-1}$ \\
\hline 0 & $17,1^{\mathrm{a}}$ & $8,0^{\mathrm{a}}$ & $164^{a}$ & $18,7^{b}$ & $9,7^{\mathrm{a}}$ & $220^{\mathrm{a}}$ & $19,0^{\mathrm{a}}$ & $10,7^{\mathrm{a}}$ & $246^{a}$ \\
\hline 40 & $19,5^{b}$ & $8,10^{\mathrm{a}}$ & $186^{\mathrm{ab}}$ & $18,4^{\mathrm{b}}$ & $9,9^{a b}$ & $222^{\mathrm{a}}$ & $18,7^{a}$ & $11,2^{\mathrm{ab}}$ & $253^{\mathrm{ab}}$ \\
\hline 80 & $18,7^{\mathrm{b}}$ & $8,5^{\mathrm{ab}}$ & $188^{\mathrm{b}}$ & $18,7^{\mathrm{b}}$ & $10,2^{\mathrm{ab}}$ & $232^{\mathrm{ab}}$ & $18,5^{\mathrm{a}}$ & $11,2^{\mathrm{ab}}$ & $252^{\mathrm{a}}$ \\
\hline 160 & $19,1^{\mathrm{b}}$ & $9,01^{b c}$ & $207^{\text {bc }}$ & $18,5^{b}$ & $10,6^{b}$ & $239^{a b}$ & $19,5^{\mathrm{a}}$ & $11,6^{\mathrm{b}}$ & $273^{c}$ \\
\hline $\mathrm{rdm}+0$ & $18,3^{\mathrm{ab}}$ & $9,6^{\mathrm{cd}}$ & $212^{c}$ & $17,1^{b}$ & $11,4^{\mathrm{c}}$ & $235^{\mathrm{ab}}$ & $18,2^{\mathrm{a}}$ & $12,5^{b}$ & $261^{\mathrm{abc}}$ \\
\hline $\mathrm{rdm}+80$ & $18,4^{\mathrm{ab}}$ & $10,0^{d}$ & $220^{c}$ & $17,3^{b}$ & $11,6^{c}$ & $246^{b}$ & $19,4^{a}$ & $11,8^{\mathrm{b}}$ & $271^{\mathrm{bc}}$ \\
\hline s.e.d. (gem) & 0,78 & 0,41 & 11,5 & 0,85 & 0,37 & 11,0 & 0,79 & 0,37 & 9,4 \\
\hline significant $^{1}$ & * & $* * *$ & $* * *$ & & $* * *$ & & & * & * \\
\hline
\end{tabular}

1) $* \mathrm{P}<0,05, * * \mathrm{P}<0,01$ and $* * * \mathrm{P}<0,001$

\subsection{Basisresultaten $\mathrm{N}$ - en P-gehalte en -opname}

De N-opbrengst (Tabel 19) varieerde overwegend tussen de 200 en $225 \mathrm{~kg} \mathrm{~N} \mathrm{ha}^{-1}$ met kleine verschillen tussen behandelingen. Het $\mathrm{N}$-gehalte was in 2016 zo'n 10\% lager dan in 2015. De Popbrengst bedroeg ongeveer $36-37 \mathrm{~kg} \mathrm{ha}^{-1}$. Dit komt overeen met ongeveer $83 \mathrm{~kg} \mathrm{P}_{2} \mathrm{O} 5 \mathrm{ha}^{-1}$. De P- en S-gehaltes zijn van een normaal niveau, waarbij de waarden in 2016 iets lager zijn dan die van 2015. 
De zwavelopbrengst bedraagt gemiddeld bijna $20 \mathrm{~kg} \mathrm{ha}^{-1}$. In beide jaren is het beeld dat de $\mathrm{K}$ bemesting weinig effect heeft op de $\mathrm{N}$-, P-, en S-gehalten. De Mg-gehalten zijn relatief laag, vooral die in 2016 (zie verderop). De Mg-opname door het gewas bedraagt in 2015 en 2016 respectievelijk gemiddeld 26 en $22 \mathrm{~kg} \mathrm{Mg} \mathrm{ha-1}$. Dit komt overeen met 43 en $37 \mathrm{~kg} \mathrm{MgO} \mathrm{ha}^{-1}$, wat ongeveer gelijk is aan de aanvoer met $35 \mathrm{~m}^{3} \mathrm{rdm} \mathrm{ha}^{-1}$.

Tabel $19 \quad N-, P-$, S-gehalte en -opbrengst per behandeling en per jaar.

\begin{tabular}{|c|c|c|c|c|c|c|c|c|c|}
\hline Behandeling & $\begin{array}{l}\text { aantal } \\
\text { a }\end{array}$ & $\begin{array}{l}\text { N-geh } \\
\mathrm{g} \mathrm{kg}^{-1} \text { ds }\end{array}$ & $\begin{array}{l}\text { N-opbr } \\
k g h a^{-1}\end{array}$ & $\begin{array}{l}\text { P-geh } \\
\mathrm{g} \mathrm{kg}^{-1} \text { ds }\end{array}$ & $\begin{array}{l}\text { P-obr } \\
\mathrm{kg} \mathrm{ha}^{-1}\end{array}$ & $\begin{array}{l}\text { Mg-geh } \\
\mathrm{g} \mathrm{kg}^{-1} \text { ds }\end{array}$ & $\begin{array}{l}\text { Mgopbr } \\
\text { kg ha-1 }^{-1}\end{array}$ & $\begin{array}{l}\text { S-geh } \\
\mathrm{g} \mathrm{kg}^{-1} \text { ds }\end{array}$ & $\begin{array}{l}\text { S-opbr } \\
\text { kg ha-1 }\end{array}$ \\
\hline \multicolumn{10}{|l|}{2015} \\
\hline OK & 36 & 12,24 & 223 & 2,01 & 37 & 1,45 & 26,6 & 0,97 & 18 \\
\hline $40 \mathrm{~K}$ & 37 & 12,40 & 225 & 2,04 & 37 & 1,42 & 25,7 & 0,97 & 18 \\
\hline $80 \mathrm{~K}$ & 39 & 12,30 & 227 & 2,01 & 37 & 1,40 & 26,0 & 0,97 & 18 \\
\hline $160 \mathrm{~K}$ & 35 & 12,49 & 225 & 2,05 & 37 & 1,39 & 25,1 & 0,98 & 18 \\
\hline $320 K^{*}$ & 9 & 11,58 & 212 & 1,82 & 33 & 1,47 & 26,8 & 0,99 & 18 \\
\hline Mest+0K & 30 & 12,10 & 224 & 1,96 & 36 & 1,38 & 25,6 & 0,96 & 18 \\
\hline Mest $+80 \mathrm{~K}$ & 33 & 12,11 & 224 & 2,02 & 37 & 1,38 & 25,7 & 0,93 & 17 \\
\hline Mest+240K* & 4 & 13,78 & 263 & 2,85 & 55 & 1,30 & 24,6 & 0,93 & 18 \\
\hline gemiddeld & 223 & 12,28 & 225 & 2,02 & 37 & 1,41 & 25,8 & 0,96 & 18 \\
\hline \multicolumn{10}{|l|}{2016} \\
\hline OK & 40 & 11,13 & 208 & 1,85 & 34 & 1,21 & 21,9 & 0,93 & 17 \\
\hline $40 \mathrm{~K}$ & 39 & 11,23 & 226 & 1,89 & 38 & 1,21 & 24,1 & 0,94 & 19 \\
\hline $80 \mathrm{~K}$ & 40 & 10,98 & 211 & 1,90 & 36 & 1,18 & 22,3 & 0,94 & 18 \\
\hline $160 \mathrm{~K}$ & 40 & 11,02 & 217 & 1,88 & 37 & 1,19 & 23,2 & 0,93 & 18 \\
\hline $320 K^{*}$ & 4 & 10,90 & 136 & 2,05 & 25 & 1,50 & 17,8 & 1,03 & 13 \\
\hline Mest+0K & 34 & 10,50 & 197 & 1,95 & 36 & 1,15 & 21,1 & 0,89 & 17 \\
\hline Mest $+80 \mathrm{~K}$ & 34 & 10,78 & 204 & 1,92 & 36 & 1,14 & 21,1 & 0,91 & 17 \\
\hline gemiddeld & 231 & 10,95 & 209 & 1,90 & 36 & 1,19 & 22,3 & 0,92 & 18 \\
\hline
\end{tabular}

* afwijkende objecten omdat er geen mest kon worden toegediend. 


\section{$5 \quad$ Modelanalyse detail- en miniproeven}

\subsection{Statistische analyse mini- en detailproeven samen}

\subsubsection{Algemeen}

Nagegaan is welke bodem- en bemestingsfactoren van invloed zijn op de drogestofopbrengst, de Kopbrengst en K-gehalte. Dit is gedaan voor de miniproeven en de detailproeven samen. Dit geeft over 2015-2017 bruto in totaal 459+520 =979 experimentele eenheden. Van de detailproeven doet de locatie Wageningen in 2016 voor de helft mee. Er is een groot verschil in opbrengstniveau tussen locaties (8-25 ton ds ha-1). Met REML kan hiervoor gecorrigeerd worden. Tegelijkertijd is bekend dat in het algemeen de respons van maïs op bijvoorbeeld $\mathrm{N}$ - of $\mathrm{P}$-bemesting niet lineair is (de meeropbrengst neemt af, naarmate de gift toeneemt). Daarom is als eerste getest of niet-lineaire multiple regressie voor de analyse van de drogestofopbrengsten, waarbij locatie-effecten worden opgenomen in het model (het verschil in productiepotentieel tussen verschillende locaties als gevolg van bijvoorbeeld verschillen in de vochtvoorziening, de gebruikte maïsrassen, de bodemstructuur etc.), een aanpak kon zijn (vergelijkbaar met de analyse van P-respons proeven in mais, Bussink et al., 2011). Dit bleek niet goed te werken mogelijk door de geringe opbrengstrespons binnen een locatie.

Tabel 20 Parameters die zijn meegenomen in de statistische analyse van de eerste snede.

\begin{tabular}{|c|c|c|}
\hline Modelparameter & Toelichting & Eenheid \\
\hline Fact_mest & factor voor geen of wel dierlijke mest & \\
\hline $\mathrm{KCaCl} 2$ & $\mathrm{~K}-\mathrm{CaCl}_{2}$ & (mg K kg-1 grond) \\
\hline MgPAE & $\mathrm{Mg}-\mathrm{CaCl}_{2}$ & (mg Mg kg-1 grond) \\
\hline PPAE & $\mathrm{P}-\mathrm{CaCl}_{2}$, fosfaat intensiteit & (mg $\mathrm{P} \mathrm{kg}{ }^{-1}$ grond) \\
\hline PAL & fosfaat capaciteit & (mg $\mathrm{P}_{2} \mathrm{O}_{5}$ per 100 gram grond) \\
\hline os & organisch stofgehalte & $(\%)$ \\
\hline CEC & Kationenuitwisselingscapaciteit & $\left(\mathrm{mmol}(+) \mathrm{kg}^{-1}\right)$ \\
\hline Lutum & kleigehalte & $(\%)$ \\
\hline $\mathrm{pH}$ & zuurgraad & \\
\hline Pkm & P-kunstmest & $\left(\mathrm{kg} \mathrm{P}_{2} \mathrm{O}_{5} \mathrm{ha}^{-1}\right)$ \\
\hline Pdm & P-dierlijke mest & $\left(\mathrm{kg} \mathrm{P}_{2} \mathrm{O}_{5} \mathrm{ha}^{-1}\right)$ \\
\hline $\mathrm{Ndm}$ & $\mathrm{N}$-dierlijke mest & $\left(\mathrm{kg} \mathrm{N} \mathrm{ha}^{-1}\right)$ \\
\hline Nkm & $\mathrm{N}$-kunstmest & $\left(\mathrm{kg} \mathrm{N} \mathrm{ha}^{-1}\right)$ \\
\hline $\mathrm{Kkm}$ & K-kunstmest & $\left(\mathrm{kg} \mathrm{K}_{2} \mathrm{O} \mathrm{ha}{ }^{-1}\right)$ \\
\hline $\mathrm{Kdm}$ & K-dierlijke mest & $\left(\mathrm{kg} \mathrm{K}_{2} \mathrm{O} \mathrm{ha-1}\right)$ \\
\hline Skm & S-kunstmest & $\left(\mathrm{kg} \mathrm{S} \mathrm{ha}^{-1}\right)$ \\
\hline Kgift & totaal werkzame $\mathrm{K}$ uit mest & $\left(\mathrm{kg} \mathrm{K}_{2} \mathrm{O} \mathrm{ha-1}\right)$ \\
\hline fMgCa_gap & Mg_bez/Ca_bez & \\
\hline fKMgCa_gap & K_bez/((Mg_bez+Ca_bez $)^{* * 0.5)}$ & \\
\hline
\end{tabular}


Daarom is bij de verdere analyse van de gehele dataset variantencomponenten analyse met REML toegepast om de $(\mathrm{K})$-opbrengst en $\mathrm{K}$-gehalte lineair te modelleren. Naast $\mathrm{K}-\mathrm{CaCl}_{2}$ (ook wel K-PAE) en $\mathrm{K}$-bemesting zijn in de analyse een groot aantal bodem- en bemestingsparameters meegenomen en getoetst (Tabel 20) zoals onder andere de CEC, pH en fosfaattoestand, welke van invloed kunnen zijn op de opbrengst. Daarnaast kan de bezetting aan het adsorptiecomplex van invloed zijn op de Kbeschikbaarheid, zeker op kleigronden. Daarom zijn 3 termen "... Gap" meegenomen die een maat zijn voor het adsorptiegedrag van K (Bussink et al., 2011). Verder zijn ook interacties tussen parameters meegenomen (beperkt tot tweeweg interacties, voor zover relevant).

De modelparameters hadden regelmatig een groot bereik. De verdeling is dan vaak niet normaal. Daarom is waar nodig een log-transformatie toegepast voor het verkrijgen van een normale verdeling. In de tekst is de natuurlijke logaritme weergegeven door "I" voorafgaand aan de parameter.

Uit de analyse bleek dat voor het effect van K-bemesting op de opbrengst eigenlijk geen onderscheid behoefde te worden gemaakt tussen kali uit kunstmest en werkzame $\mathrm{K}$ uit rundveemest. Dit komt overeen met de bevindingen in de detailproeven. Als modelparameter voor het effect van kalibemesting is daarom de werkzame Kgift als modelparameter meegenomen. Ook voor $\mathrm{N}$ hoefde er geen onderscheid te worden gemaakt tussen $\mathrm{N}$ uit kunstmest en werkzame $\mathrm{N}$ uit rundveemest. Voor het effect van $\mathrm{N}$-bemesting is daarom de werkzame $\mathrm{Ngift}$ als modelparameter meegenomen.

\subsubsection{Drogestofopbrengst: $\mathrm{CEC}$ en $\mathrm{K}-\mathrm{CaCl}_{2}$}

Bij de REML variantie componenten analyse is rekening gehouden met de verschillen tussen locaties en jaren door als toevalsfactor (random term) Locatie.Jaar mee te nemen. Voor de verklaring van de drogestofopbrengst zijn de parameters uit Tabel 20 getoetst. Dit resulteerde uiteindelijk in een Model 1 met 77,3\% verklaarde variantie (18 uitbijters). De random factor (Locatie.perceel) verklaarde ongeveer $67,5 \%$ van de variantie. De modelfactoren verklaarden $10 \%$ van de resterende variantie. Dit is als redelijk te beschouwen gezien de grote bijdrage van de random factoren.

De significanties van de modelparameters zijn in Tabel 23 weergegeven. Er zijn veel parameters die van invloed zijn op de opbrengst, waaronder $\mathrm{K}, \mathrm{CEC}$, de bezetting van het adsorptiecomplex (fKCa_gap en fMgCa_gap) en de (werkzame) Kgift. Er is een negatieve interactie tussen Kgift en K$\mathrm{CaCl}_{2}$. Dit wil zeggen dat het effect van $\mathrm{K}$-bemesting op de opbrengst afneemt naarmate $\mathrm{K}-\mathrm{CaCl}_{2}$ hoger is. Verder is Fact_mest negatief. Dat wil zeggen dat op de objecten met mest de opbrengst 1 ton lager is dan op de objecten zonder mest. Om de effecten inzichtelijk te maken zijn in figuur 10 de gemodelleerde opbrengsten weergegeven voor verschillende $\mathrm{K}-\mathrm{CaCl}_{2}$ en $\mathrm{K}_{2} \mathrm{O}$-bemestingen. Daarbij is voor alle andere parameters van het model het gemiddelde van de betreffende parameter genomen. Te zien is dat in het traject $20-60 \mathrm{~K}-\mathrm{CaCl}_{2}$ er een positief effect is van bemesting dat daalt naar 0 richting $\mathrm{K}-\mathrm{CaCl}_{2}=60$. In tabel 21 is dit in detail weergegeven. Bij hogere waarden van $\mathrm{K}-\mathrm{CaCl}_{2}$ daalt de opbrengst naarmate er meer kali wordt bemest en bij hogere $\mathrm{K}-\mathrm{CaCl}_{2}$ daalt bovendien ook de opbrengst. Dit is zeer opvallend. Het uitmiddelen van de andere modelfactoren kan enige invloed hebben. Zo zal bij een hogere $\mathrm{K}-\mathrm{CaCl}_{2}$ in het algemeen de $\mathrm{K}$-bez ook iets hoger zijn, wat de opbrengst positief beïnvloedt. Echter het meest eenvoudig model met alleen IKgift + IKCaCl2 + IKgift.IKCaCl2 gaf een vergelijkbaar beeld te zien als figuur 10 (niet getoond). Een iets uitgebreidere parameterisatie (via model 2; R2 = 77,8\% en 17 uitbijters) vertoont tot ongeveer $\mathrm{K}-\mathrm{CaCl}_{2} 60$ en een $\mathrm{K}$-gift van $60 \mathrm{~K}{ }_{2} \mathrm{O}$ $\mathrm{ha}^{-1}$ een positief effect op de opbrengst (Tabel 22). Boven deze waarden is het effect op de opbrengst eveneens negatief. Op basis van deze analyses is een hoge $\mathrm{K}-\mathrm{CaCl}_{2}$ en een hoge Kaligift dus ongunstig voor de opbrengst. 
Model 1: Drogestofopbrengst

Response variabele: Dsopbrengst

Fixed model: $\quad$ Constant + IKgift $+\mathrm{IKCaCl} 2+\mathrm{IKgift} . \mathrm{IKCaCl} 2+\mathrm{INgift}+$ Sgiftk $+\mathrm{SLV}+\mathrm{Mg} \_$bez + $\mathrm{K} \_$bez + CEC + Fact_mest + K_bez.CEC + K_bez.Fact_mest + IPPAE + ratio

Random model: $\quad$ locatie.JaarKadertekst

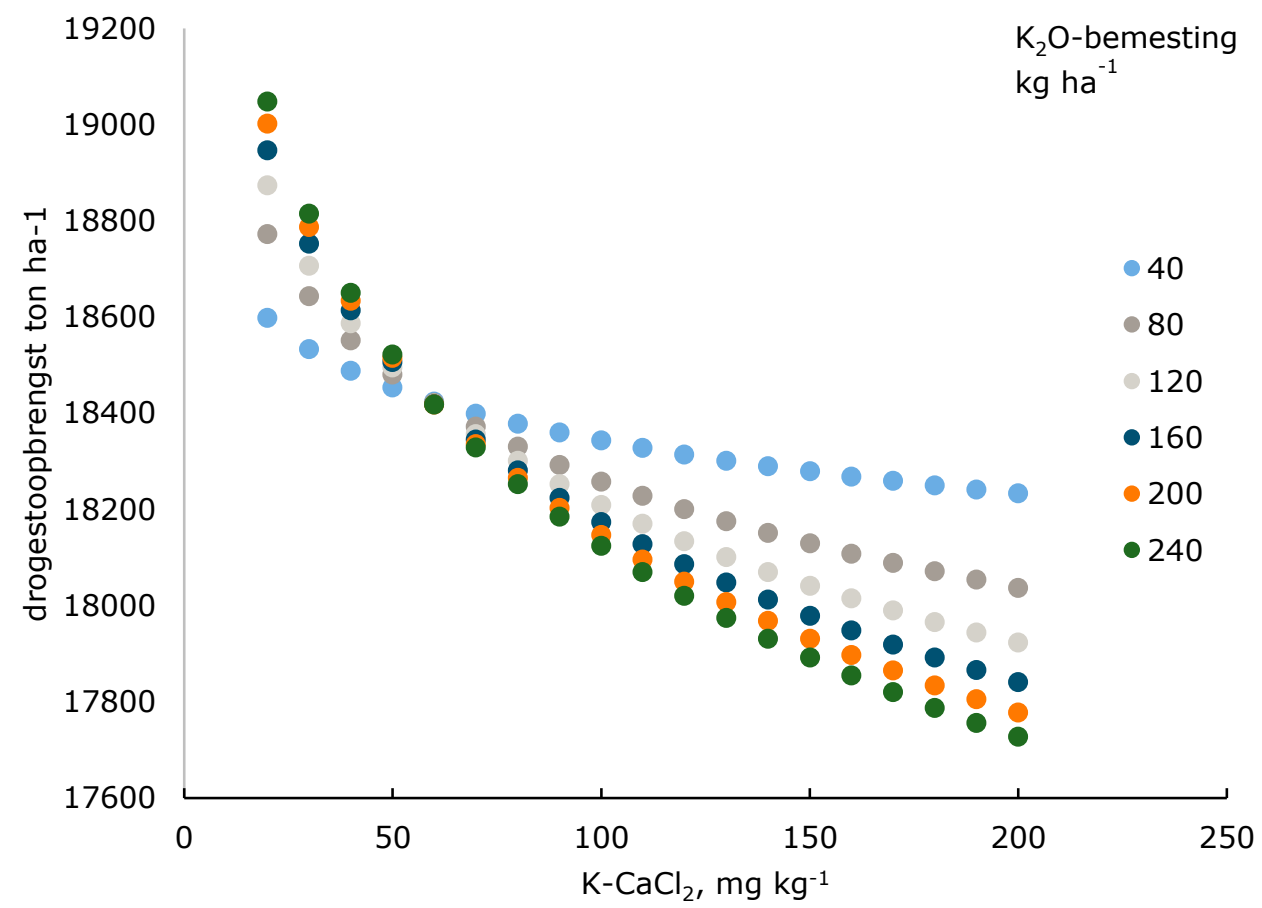

Figuur 10 Het effect kalibemesting op de drogestofopbrengst bij verschillende $K-C a C l 2$ (KPAE) waarden op basis van model 1. (ratio gem: 37.22, IPPAE gem::0.6629, K_bez gem: 3.466, CEC gem: 124.7, Mg_bez gem: 13.55, SLVgem: 12.17, Sgiftk gem: 16.41, INgift : 5.362).

Tabel 21 De meeropbrengst door kalibemesting bij lage K-CaCl2 op basis van model 1.

\begin{tabular}{|c|c|c|c|c|c|c|}
\hline \multicolumn{3}{|c|}{$\mathrm{K}-\mathrm{CaCl}_{2}$} & \multicolumn{4}{|c|}{$\mathrm{kg} \mathrm{K}_{2} \mathrm{O} \mathrm{ha}^{-1}$} \\
\hline 20 & 928 & 1102 & 1204 & 1276 & 1332 & 1378 \\
\hline 30 & 580 & 690 & 753 & 799 & 834 & 862 \\
\hline 40 & 334 & 397 & 433 & 460 & 480 & 496 \\
\hline 60 & -12 & -15 & -16 & -17 & -18 & -18 \\
\hline
\end{tabular}


Model 2: Drogestofopbrengst

Response variate: Dsopbr

Fixed model: $\quad$ Constant + IKgift + IKCaCl2 + IKgift.IKCaCl2 + INgift + Sgiftk + SLV + Mg_bez + $\mathrm{CEC}+$ Fact_mest $+\mathrm{K} \_$bez + IPPAE + IPPAE.IKCaCl2 + ratio + fKMg_gap + Fact_mest.fKMg_gap + IMgPAE + SLV.CEC + CEC.fKMg_gap + $\mathrm{KCaCl} 2+\mathrm{Kgift}+$ $\mathrm{KPCaICl}$ 2.Kgift

Random model locatie.Jaar

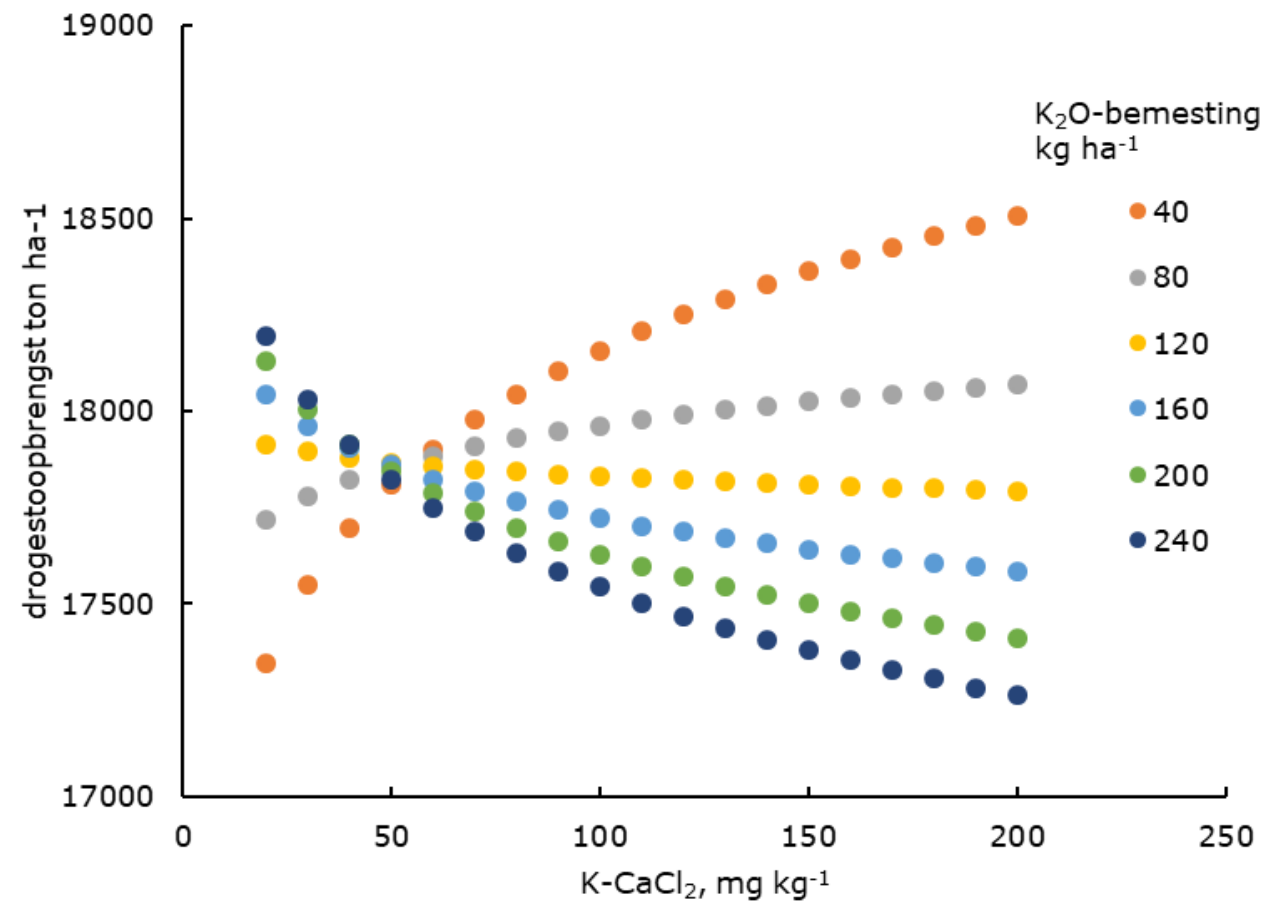

Figuur 11 Het effect kalibemesting op de drogestofopbrengst bij verschillende $K-\mathrm{CaCl}_{2}(K P A E)$ waarden op basis van model 2. (ratio gem: 37.22, IPPAE gem:: 0.6629, K_bez gem: 3.466, CEC gem: 124.7, Mg_bez gem: 13.55, SLVgem: 12.17, Sgiftk gem: 16.41, INgift : 5.362).

Tabel 22 De meeropbrengst door kalibemesting bij lage $\mathrm{K}-\mathrm{CaCl}_{2}$ op basis van model 2.

\begin{tabular}{|c|c|c|c|c|c|c|}
\hline \multicolumn{3}{|c|}{$\mathrm{K}-\mathrm{CaCl}_{2}$} & \multicolumn{4}{|c|}{$\mathrm{kg} \mathrm{K}_{2} \mathrm{O} \mathrm{ha}^{-1}$} \\
\hline 20 & 2180 & 2552 & 2750 & 2877 & 2965 & 3028 \\
\hline 30 & 1422 & 1651 & 1766 & 1833 & 1875 & 1901 \\
\hline 40 & 883 & 1011 & 1067 & 1092 & 1102 & 1101 \\
\hline 60 & 125 & 110 & 82 & 49 & 12 & -26 \\
\hline
\end{tabular}


Tabel 23 De richtingscoëfficiënt (rc) en de standaardafwijking (se) van model 1 en 2 voor de drogestofopbrengst.

\begin{tabular}{|c|c|c|c|c|c|}
\hline Model 1 & & & Model 2 & & \\
\hline Parameter & rc & se & Parameter & rc & se \\
\hline IKgift & 946,2 & 228,44 & IKgift & 2123 & 317,4 \\
\hline $\mathrm{IKCaCl} 2$ & 697,3 & 322,46 & $\mathrm{IKCaCl} 2$ & 1970 & 497,8 \\
\hline INgift & 1002 & 302,7 & INgift & 1028 & 300,7 \\
\hline Sgiftk & 25,73 & 6,446 & Sgiftk & 24,69 & 6,646 \\
\hline SLV & 57,81 & 23,656 & SLV & $-88,55$ & 44,649 \\
\hline CEC & $-10,38$ & 4,233 & K_bez & -2269 & 733,9 \\
\hline K_bez.CEC & 4,713 & 1,3574 & IPPAE & -3387 & 975,9 \\
\hline IPPAE & $-586,2$ & 192,64 & IKCaCl2.IPPAE & 615,6 & 252,47 \\
\hline ratio & $-47,89$ & 9,648 & ratio & $-47,4$ & 10,821 \\
\hline Fact_mest2 & -1038 & 266,1 & fKMg_gap & 6923 & 3098,4 \\
\hline \multirow[t]{3}{*}{ Fact_mest.K_bez } & 193,14 & 193,4 & IMgPAE & 1667 & 478,8 \\
\hline & & & SLV.CEC & 0,8233 & 0,22905 \\
\hline & & & Fact_mest & $-1419,3$ & $-347,2$ \\
\hline $\mathrm{R} 2$ & 77,3 & & & 77,83 & \\
\hline $\mathrm{n}=$ & 954 & & & 957 & \\
\hline
\end{tabular}

\subsection{3 $\mathrm{K}(2 \mathrm{O})$-opbrengst: $\mathrm{CEC}$ en $\mathrm{K}-\mathrm{CaCl}_{2}$}

De modellering van het $\mathrm{K}$-gehalte (Tabel 24) geeft aan dat diverse parameters van invloed zijn op het $\mathrm{K}$-gehalte. De kaligift, $\mathrm{K}-\mathrm{CaCl}_{2}$ en $\mathrm{CEC}$ en hun interacties zijn van invloed op het $\mathrm{K}$-gehalte in mais. Ook de magnesiumbemesting en de magnesiumtoestand zijn van invloed en hebben interacties met andere parameters. Zo verlaagt magnesiumbemesting en een hoge magnesiumtoestand de $\mathrm{K}$ opbrengst (IMggift.Kgift en IKCaCl2.IMgPAE) en de het K-gehalte (bijv. INgift.IMggift). De relaties zijn complex en worden nu niet nader geduid. Van belang is vooral om aan te geven dat gemeten waarden niet alleen kunnen worden toegeschreven aan behandelingseffecten ( $\mathrm{K}$-bemesting en $\mathrm{K}$ toestand). Ook de CEC is van belang voor het $\mathrm{K}$-gehalte en $\mathrm{K}$-opbrengst. Ook deze vertoont interacties met andere parameters, waarbij op basis van het niveau van de richtingscoëfficiënten van alle termen met CEC het beeld is dat een hoge CEC het $\mathrm{K}$-gehalte en de $\mathrm{K}$-opname drukt. Dat is aanschouwelijk gemaakt in figuur 12 en 13 , waarin het $\mathrm{K}$-gehalte en de $\mathrm{K}_{2} \mathrm{O}$-opbrengst zijn weergegeven als functie van $\mathrm{CEC}, \mathrm{K}-\mathrm{CaCl}_{2}$ en kaligift. Voor alle andere parameters zijn de gemiddelde waarden gebruikt om de afhankelijkheid van het $\mathrm{K}$-gehalte van $\mathrm{CEC}, \mathrm{K}-\mathrm{CaCl}_{2}$ en kaligift te voorspellen op basis van de met Genstat afgeleide statistische relatie. Figuur 12 laat zien dat een hoge CEC het effect van bemesting op het $\mathrm{K}$-gehalte minimaliseert. Veel belangrijker is dan het niveau van $\mathrm{K}-\mathrm{CaCl}_{2}$, waarbij een vele hoger $\mathrm{K}-\mathrm{CaCl}_{2}$ nodig is bij een hoge $\mathrm{CEC}$ dan bij een lage $\mathrm{CEC}$ om eenzelfde $\mathrm{K}$-gehalte te realiseren. Een vergelijkbaar beeld is aanwezig bij de $\mathrm{K}_{2} \mathrm{O}$-opbrengst (figuur 13). 
Tabel 24 De richtingscoëfficiënt (rc) en de standaardafwijking (se) van het model 3 (Kopbr, $k g$ ha ${ }^{1}$ ) en 4 (K-gehalte, $\mathrm{mg} \mathrm{kg}^{-1}$ ) voor de drogestofopbrengst.

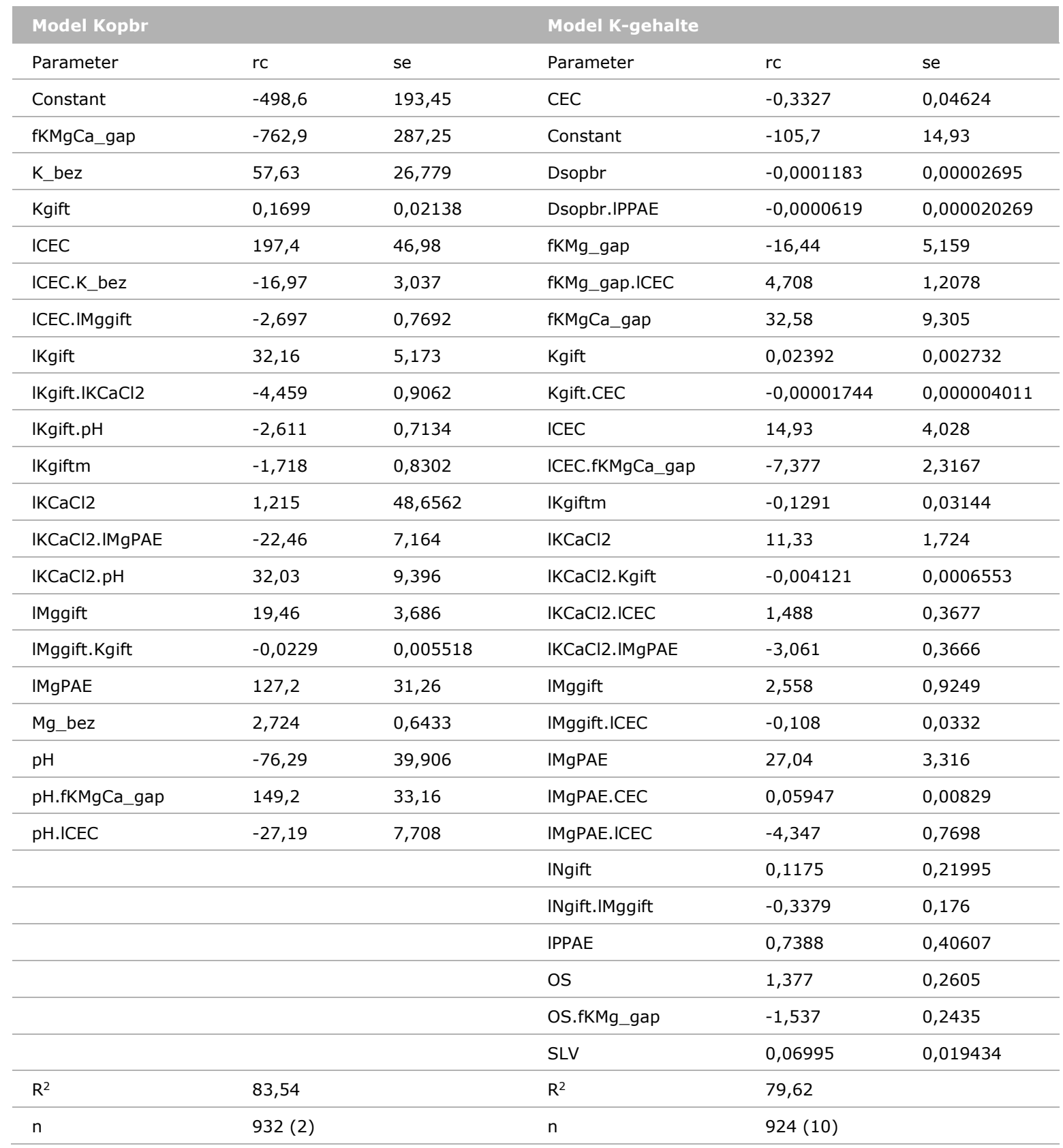



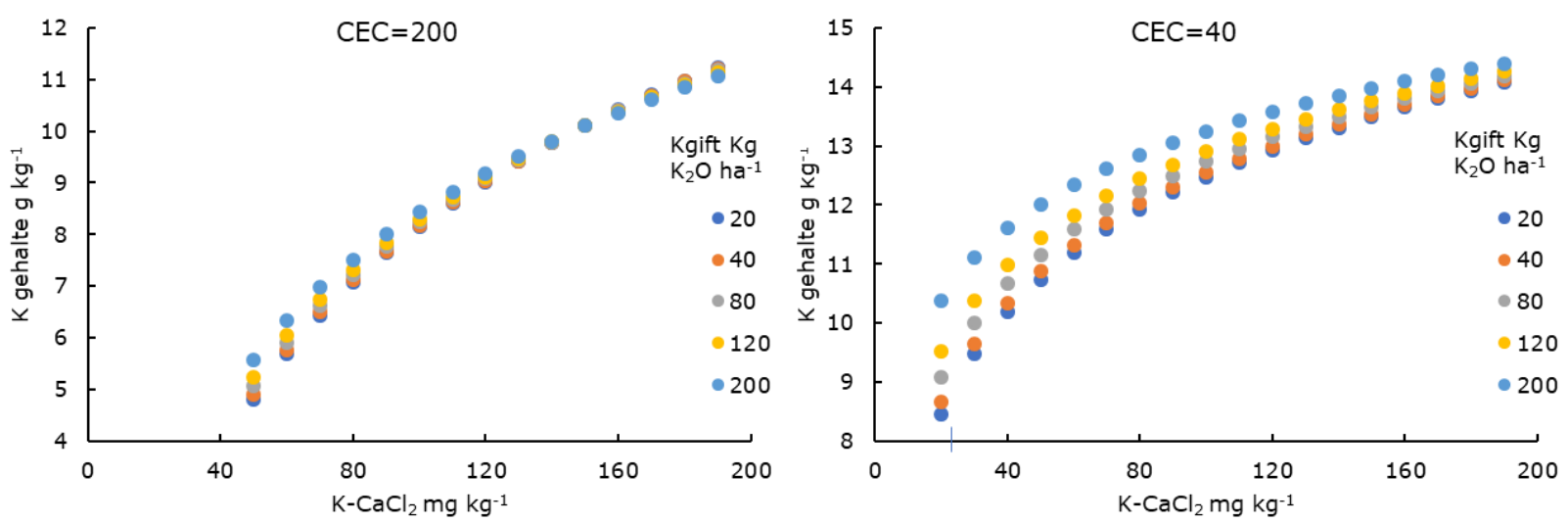

Figuur 12 Het effect kalibemesting op het $K$-gehalte bij verschillende $K-\mathrm{CaCl}_{2}$ (KPAE) waarden voor 2 niveaus van CEC op basis van model 4. (fKMgCa_gap gem: .3783, IPPAE gem:: 0.6881, Dsopb gem: 19003, fKMg_gap gem: .9421, IMggift gem: 2.673, SLVgem: 12.14, IKgiftm gem: 2.02, INgift : 5.37, OS gem: 4.2178, IMgPAE gem: 4.648).
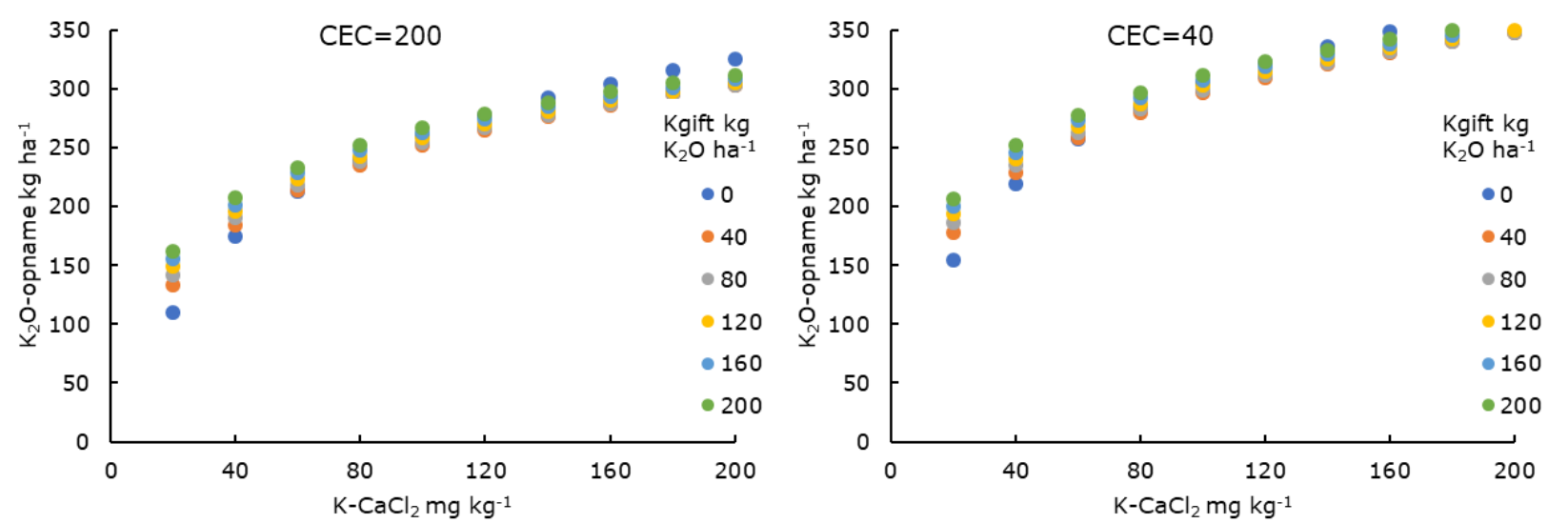

Figuur 13 Het effect kalibemesting op de K2O-opbrengst bij verschillende K-CaCl2 (KPAE) waarden voor 2 niveaus van CEC op basis van model 4. (fKMgCa_gap gem: .3776, IPPAE gem:: 0.6881, Mg_bez: 13.78, K-bez gem: 3.516, IMggift gem: 2.676, IKgiftm gem: 2.037, pH gem: 5.645, IMgPAE gem: 4.647 ).

\subsubsection{Drogestofopbrengst: $\mathrm{K}-\mathrm{HCl}$}

De grondmonsters zijn met uitzondering van de 2015 miniproeven ook geanalyseerd op $\mathrm{K}-\mathrm{HCl}$. Bekend is dat er een goede relatie bestaat tussen $\mathrm{K}-\mathrm{CaCl}_{2}$ en $\mathrm{K}-\mathrm{HCl}$ voor gronden met een lage CEC c.q. lutumgehalte zoals de zandgronden (Van Rotterdam-Los, 2010). Op kleigronden wordt er met $\mathrm{K}-\mathrm{HCl}$ beduidend meer $\mathrm{K}$ geëxtraheerd dan met $\mathrm{K}-\mathrm{CaCl}_{2}$. Op basis van lineaire regressie zijn de volgende relaties gevonden tussen $\mathrm{K}-\mathrm{HCl}$ en $\mathrm{K}-\mathrm{CaCl}_{2}$ en Lutum ( $\mathrm{vgl} 3$ ) en $\mathrm{K}-\mathrm{CaCl}_{2}$ en $\mathrm{CEC}$ (vgl. 4), met respectievelijk 3 en 6 uitbijters.

$\mathrm{K}-\mathrm{HCl}=-5.672( \pm 0,864)+0,201( \pm 0,0065) * \mathrm{~K}^{-\mathrm{CaCl}_{2}}+0,07484( \pm 0,00576) *$ Lutum, $\mathrm{R}^{2}$ adj $=97,2, \mathrm{n}=41$

$\mathrm{K}-\mathrm{HCl}=-3.092( \pm 0,726)+0,204( \pm 0,0063) * \mathrm{~K}-\mathrm{CaCl}_{2}+0,5335( \pm 0,0369) * \mathrm{CEC}, \mathrm{R}^{2}{ }_{\mathrm{adj}}=97,2, \mathrm{n}=44$

Toevoegen van $\mathrm{K}-\mathrm{HCl}$ als extra parameter aan het drogestofrespons model (Tabel 23) en aan de $\mathrm{K}$ opbrengstmodel (Tabel 24) gaf geen significante verbetering. Anderzijds leidde het vervangen van $\mathrm{K}$ $\mathrm{CaCl}_{2}, \mathrm{CEC}$ (K_bez) en fKMg_gap door $\mathrm{K}-\mathrm{HCl}$ tot duidelijk slechter verklarende modellen. 


\subsection{Kritisch K-gehalte en gewasopname}

De proefresultaten lieten een (beperkt) effect van K-bemesting op de opbrengst zien bij $\mathrm{K}-\mathrm{CaCl}_{2}$ waarden beneden de $60 \mathrm{mg} \mathrm{K} \mathrm{kg}-1$ grond. Bovendien is gebleken dat beneden deze waarden de maximale opbrengst is te verkrijgen door K-bemesting, waarbij een hoeveelheid die veel kleiner is dan de gewasonttrekking (40-80 $\mathrm{kg} \mathrm{K}_{2} \mathrm{O} \mathrm{ha}{ }^{-1}$ ) volstaat. Dat lijkt op zich vreemd, maar laat zich waarschijnlijk verklaren door K-nalevering uit diepere bodemlagen. In de jeugdgroeifase moet de mais de kali vooral uit de toplaag halen vanwege een nog beperkt ontwikkeld wortelstelsel. Van belang is dan voldoende beschikbaar kali in de toplaag, mede te realiseren door bemesting. Bij de verdere groei van de mais wortelt het gewas steeds dieper en wel tot meer dan $60 \mathrm{~cm}$ diep indien er geen sterke verdichting in de ondergrond is. Te verwachten is dat door het uitgevoerde bemestingsmanagement van voorgaande jaren diepere bodemlagen ook relatief veel kali bevatten (op zandgronden mogelijk

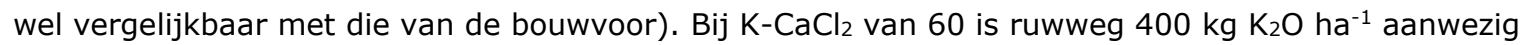
in de bouwvoor en inclusief de ondergrond mogelijk wel $1000 \mathrm{~kg} \mathrm{~K}_{2} \mathrm{O} \mathrm{ha}{ }^{-1}$. Indien de kali in de bouwvoor volledig beschikbaar zou zijn dan is dat al ruimschoots meer dan de $\mathrm{K}_{2} \mathrm{O}$-opname van een goed producerend maisgewas. Op de lange termijn gezien kan een bemesting van 40-80 $\mathrm{kg} \mathrm{K}_{2} \mathrm{O} \mathrm{ha-1}$ niet toereikend zijn. Er vindt immers uitmijning plaats waarbij zeker op zandgronden de kaligehalten in de bodem zullen dalen. Bovendien kan kali op de lichtere gronden gemakkelijk uitspoelen (in een natte winter kan kali wel een meter diep worden verplaatst). Daar tegenover staat dat door capillaire opstijging een deel van deze kali alsnog beschikbaar is voor het gewas, vooral in het tweede deel van het groeiseizoen. Voor een te ontwikkelen $\mathrm{K}$-advies voor mais ligt het dan voor de hand om te bemesten op basis van gewasonttrekking, gecorrigeerd voor de K-toestand.

In oudere experimenten in Nederland (Prummel, 1966) was er wel een sterk K-effect bij lage bodem waarden $\left(\mathrm{K}-\mathrm{HCl}<80 \mathrm{mg} \mathrm{K}{ }_{2} \mathrm{O} \mathrm{kg}{ }^{-1} \approx 66 \mathrm{mg} \mathrm{K}-\mathrm{CaCl}_{2} \mathrm{~kg}^{-1}\right.$ ). Mogelijk was er destijds minder $\mathrm{K}$ aanwezig in diepere lagen. In recente experimenten is de $\mathrm{K}$-reactie van maïs beperkt en sterk afhankelijk van de bodemtoestand. Kovacevic et al. (2009) hebben een opbrengstreactie van ongeveer $10 \%(\mathrm{~K}-\mathrm{HCl}<$ $100 \mathrm{mg} \mathrm{K}_{2} \mathrm{O} \mathrm{kg}{ }^{-1}$ ) waargenomen. In een driejarige studie in Canada (Nourayne et al. 2009) was er slechts in één jaar een opbrengsteffect bij het achterwege laten van K-bemesting. Nochtans kan bij zeer lage bodemwaarden het opbrengsteffect groot zijn zoals blijkt uit een driejarige proef van Herrmann et al. (2014) en een eenjarige proef op zandgrond van Martineau et al. (2017). Op zandige (zeezand) grond in Noord-Duitsland met een $\mathrm{K}-\mathrm{CAL}<3 \mathrm{mg} \mathrm{K} 2 \mathrm{O} / 100 \mathrm{~g}\left(\approx 25 \mathrm{mg} \mathrm{K}-\mathrm{CaCl}_{2} \mathrm{~kg}^{-1}\right.$ ), werden opbrengststijgingen van meer dan 4 ton ds ha-1 gemeten bij bemesting met $100 \mathrm{~kg} \mathrm{~K}_{2} \mathrm{O} \mathrm{ha}{ }^{-1}$. Giften van 200 of $300 \mathrm{~kg} \mathrm{ha}^{-1}$ leidden niet tot nog hogere opbrengsten. Herrmann et al. (2014) stelden vast dat het kritieke $\mathrm{K}$-gehalte $8,3 \mathrm{~g} \mathrm{~kg}^{-1} \mathrm{ds}$ bedroeg bij een opbrengst van 13 ton ds ha-1.
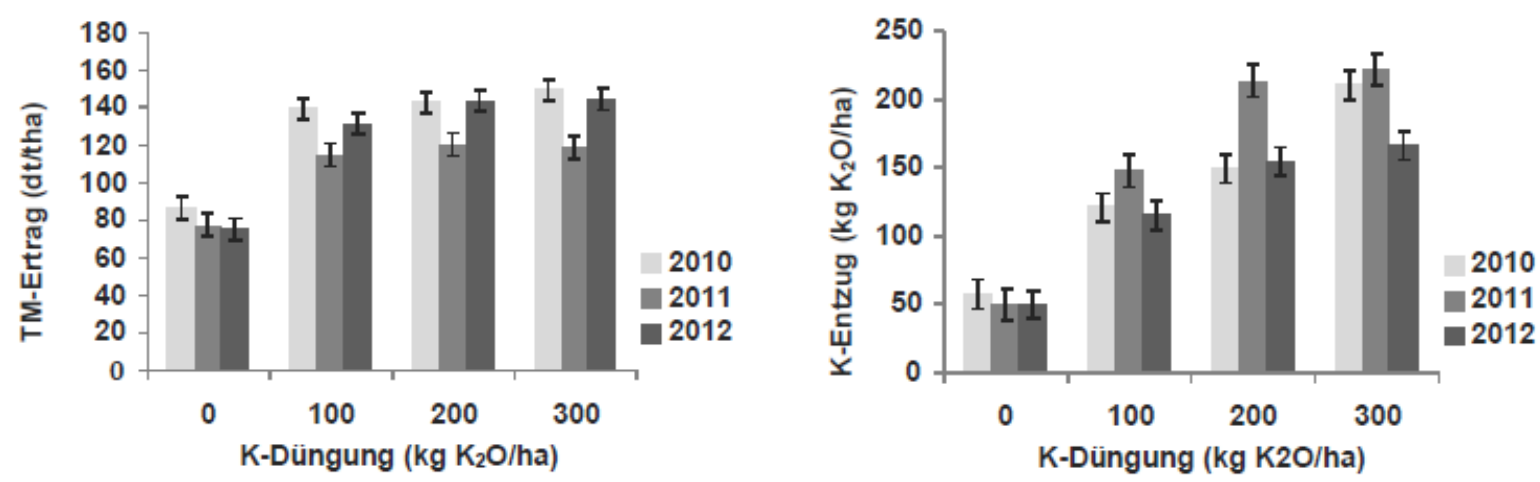

Figuur 14 Het effect van K-bemesting op een K-arme (zee)zand grond in NW Duitsland. 


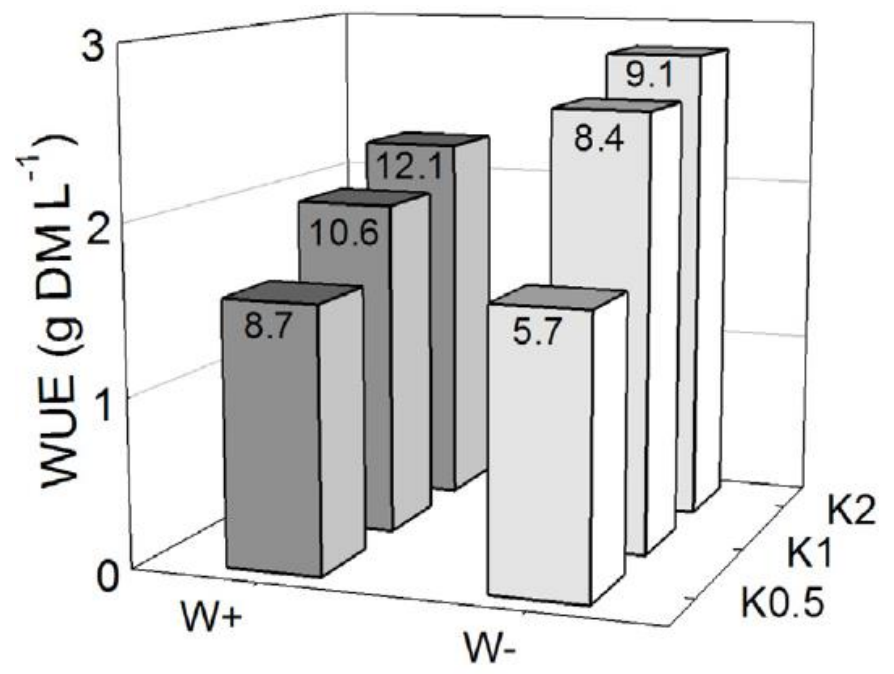

Figuur 15 Het effect van watertoediening (donker: W+ en grijs: $W$-) en K-behndeling op de wateruse efficiency. De nummers gegeven de maisopbrengst in ton per ha an (uit Martineau et al., 2017)

In een proef in 2015 van Martineau et al. (2017) op zandgrond met 3 verschillende $\mathrm{K}$-toestanden ( $\mathrm{K} 0.5$ = laag $22 \mathrm{mg} \mathrm{K} \mathrm{kg}^{-1}, \mathrm{~K} 1=31 \mathrm{mg} \mathrm{K} \mathrm{kg}^{-1}$ en $\mathrm{K} 2=$ hoog $=69 \mathrm{mg} \mathrm{K} \mathrm{kg}^{-1}$ in de laag $\left.0-50 \mathrm{~cm}\right) \mathrm{met}$ bijbehorende bemestingsniveaus van respectievelijk 0, 20 en $80 \mathrm{~kg} \mathrm{~K} \mathrm{ha}^{-1}$ bij wel (W-) en geen droogtestress $(\mathrm{W}+$ ) werden duidelijke effecten van een goede K-voorziening gevonden (zie ook H7.2). De opbrengst (Figuur 14) bij geen watertekort bedroeg bij de K2 12,1 ton korrel ha-1 (bij $77 \%$ in de korrel kom dit ruwweg overeen met 17 ton ds ha-1). De gegevens duiden erop dat $80 \mathrm{~kg} \mathrm{~K} \mathrm{ha}^{-1}$ (ofwel $96 \mathrm{~kg} \mathrm{~K}_{2} \mathrm{O} \mathrm{ha}{ }^{-1}$ ) toereikend was om optimaal te produceren bij een $\mathrm{K}$-gehalte in de bodem van $69 \mathrm{mg}$ $\mathrm{K} \mathrm{kg}^{-1}$. De behandeling $\mathrm{W}+$ met $20 \mathrm{~kg} \mathrm{~K} \mathrm{ha}^{-1}$ en $31 \mathrm{mg} \mathrm{K} \mathrm{kg}^{-1}$ in de bodem bleef daar anderhalve ton korrel $(13 \%)$ bij achter. Qua orde van grootte stemt dit overeen met de opbrengstverschillen die in onze proeven zijn gemeten bij lage bodemtoestanden en bemestingen (zie Tabel 22). Uit de proeven van Martineau is moelijker een kritisch $\mathrm{K}$-gehalte af te leiden. Bladmetingen ten tijde van de bloei gaven bij waterstress respectievelijk K-gehalten van 4.9, 16.2 en $26.3 \mathrm{~g} \mathrm{~K} \mathrm{~kg}^{-1}$ ds voor $\mathrm{K} 0.5, \mathrm{~K} 1$ en $\mathrm{K} 2$ en bij geen waterstress $7.0,14.0$ en $25.0 \mathrm{~g} \mathrm{~K} \mathrm{~kg}^{-1} \mathrm{ds}$. Een K-gehalte tussen 14 en $25 \mathrm{~g} \mathrm{~K} \mathrm{~kg}^{-1} \mathrm{ds}$ lijkt optimaal te zijn, maar na de bloei groeit het gewas door en kan een verdere verdunning optreden. Volgens Jiang et al. (2018) zijn typische gehalten voor de korrel en het blad/stro bij de oogst respectievelijk 3,5 en 12,5 g kg-1 ds bij geen opbrengstderving. De bevindingen zijn gebaseerd op basis van een meta-analyse van een 60-tal proeven op diverse locaties in China. Afhankelijk van de

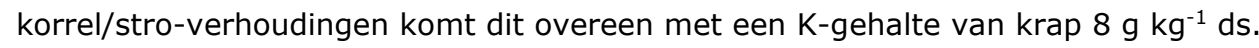

Onze experimenten geven een kritisch K-gehalte van ongeveer 8,0-8,5 g K kg-1 (Tabel 17 en Figuur 7). Deze waarde stemt goed overeen met de waarde afgeleid door Herrmann et al. (2014) en de gerapporteerde waarden door Jiang et al. (2018). Een waarde van $8,0-8,5 \mathrm{~g} \mathrm{~kg}^{-1} \mathrm{ds}$ is veel lager dan de waarde van $13 \mathrm{~g} \mathrm{~kg}^{-1}$ ds zoals die in het verleden is voorgesteld door Leigh en Jones (1984), als een indicator voor een adequate K-voorziening. De vraag is of er andere argumenten zijn om voor het te ontwikkelen K-advies van een hogere waarde dan $8,3 \mathrm{~g} \mathrm{~K} \mathrm{~kg}^{-1} \mathrm{ds}\left(10 \mathrm{~g} \mathrm{~K}_{2} \mathrm{O} \mathrm{kg} \mathrm{g}^{-1} \mathrm{ds}\right)$ uit te gaan. Eén van de belangrijke effecten die aan een goede kalivoorziening worden toegeschreven is dat het gewas beter bestand is tegen droogte, zie paragraaf 7.2, waardoor het gewas beter kan blijven produceren. Op basis van de proefresultaten van Martineau et al. (2017) en de gemeten opbrengsten bij lage toestanden (Figuur 7) zijn er weinig aanwijzingen dat echt hoge bemestingen nodig zijn om mais beter resistent te maken tegen droogte (verhogen van de wateruse efficiency, WUE). Een beperkte $\mathrm{K}$-gift ( $<100 \mathrm{~kg} \mathrm{~K}_{2} \mathrm{O} \mathrm{kg}{ }^{-1}$ ha) volstond. Bovendien blijkt uit de proeven van Martineau duidelijk dat kalium het effect van droogtestress niet opheft. 


\subsection{Mechanismen hoe kalium droogtetolerantie maïs beïnvloedt}

Kalium ondersteunt planten in hun vermogen om beter om te gaan met verschillende stress-situaties, zoals droogte, hoge lichtintensiteit of hoge temperaturen (Hasanuzzaman et al. 2018). De auteurs geven aan dat een adequate K-voorziening in de context van klimaatverandering een belangrijke rol kan spelen om beter bestand te zijn tegen stresssituaties. Planten met een tekort aan $\mathrm{K}$ lijken een acute gevoeligheid voor watertekort te ontwikkelen terwijl planten met een voldoende K-voorziening dit niet tonen (Aslam, 2013).

Kalium is betrokken bij alle processen in de plant die gebaseerd zijn op watertransport: stomatale regulatie, translocatie van fotoassimilaten en enzymactivering. Zonder $\mathrm{K}$ is er geen goed transport van minerale verbindingen zoals nitraten, fosfaten in de plant (Hasanuzzaman et al. 2018). Een complex geheel van mechanismen wordt verondersteld verantwoordelijk te zijn voor het vermogen van kalium om de droogtetolerantie van planten te ondersteunen. Er is echter ook een eenvoudige verklaring mogelijk: voldoende aanbod van $\mathrm{K}$ ondersteunt de wortelgroei die het wateropnamevermogen in geval van droogte zal verbeteren (Hasanuzzaman et al. 2018).

$\mathrm{Er}$ zal kort nader worden ingegaan op enkele mechanismen waarbij $\mathrm{K}$ de droogtetolerantie ondersteunt door vermindering van oxidatieve stress en verbetering van de controle op de opening van de stomata. In situaties van droogtestress produceren planten reactieve zuurstofspecies (ROS). Deze ROS worden geëlimineerd door $\mathrm{K}$, terwijl ze anders een verhoogde membraanpermeabiliteit en bijgevolg waterverlies veroorzaken (Hasanuzzaman et al. 2018). In situaties van droogte moeten planten hun evapotranspiratie zo veel mogelijk beperken om waterverlies te verminderen. Voor een goede en snelle sluiting van de stomata hebben planten behoefte aan $\mathrm{K}$. In maïsproeven op zandgrond met verschillende K-bemestingsniveaus hebben Martineau et al. (2017, p.68) een 17\% lagere evapotranspiratie (ET) gemeten bij geen K-bemesting ten opzichte van een adequate K-bemesting.

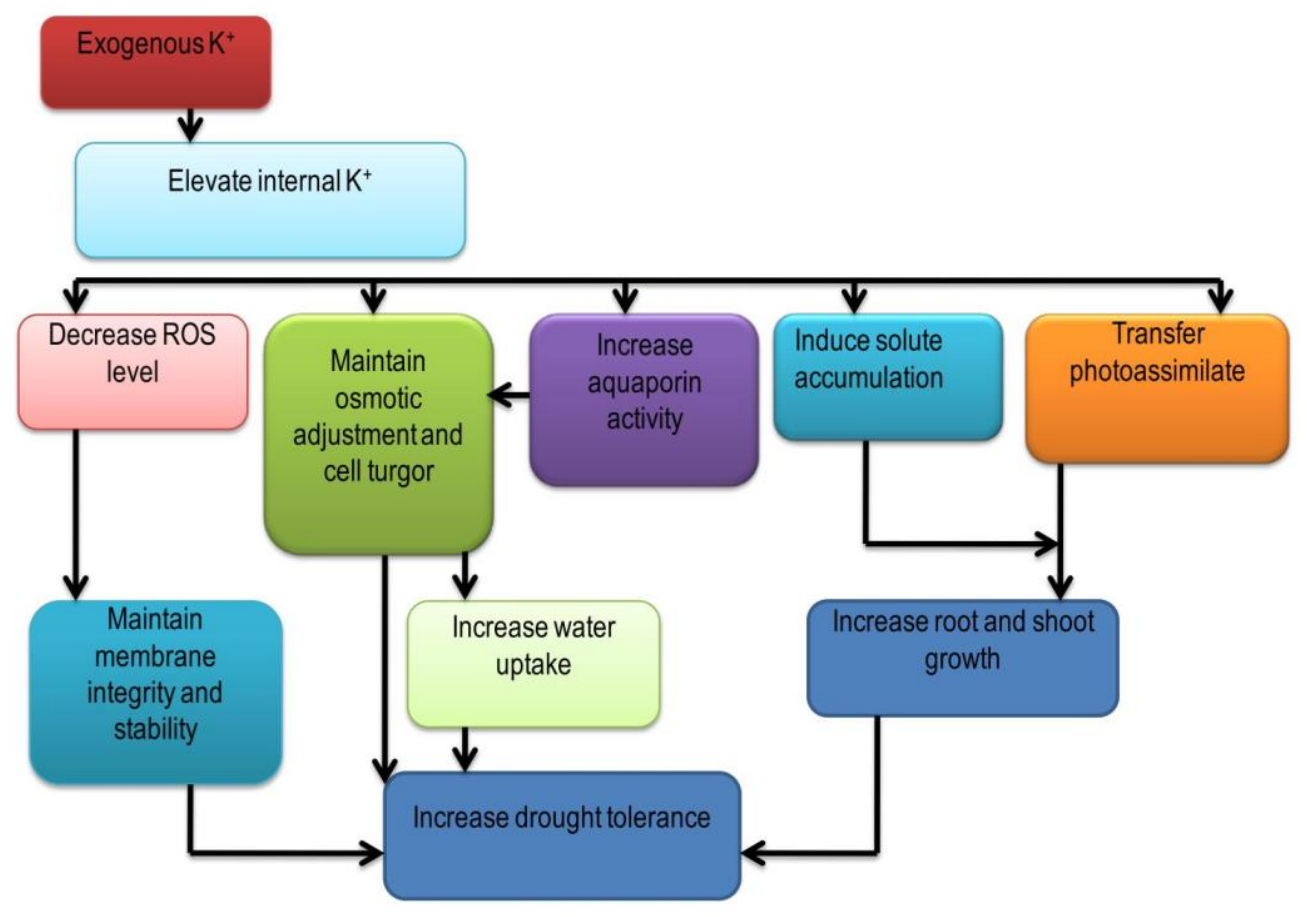

Figuur 16 De rol van kali onder droogtestress (uit: Hasanuzzaman et al. 2018).

Het complexe systeem van verschillende mechanismen is weergegeven in figuur 16 . Naast de bovengenoemde mechanismen, verhoogt kali de productie van aquaporine (eiwitten die water door een celmembraan heen geleiden), leidend tot een vermindering van de hydraulische wortelgeleiding en de productie van organische osmolyten die de droogtetolerantie van planten verhogen. Er zijn diverse effecten van $\mathrm{K}$ die elkaar deels tegenwerken als het gaat om efficiënt van het watergebruik van maïsplanten. Martineau et al. (2017 blz. 68) concludeerden uit hun veldproeven dat de watergebruiksefficiëntie van maïsplanten was verhoogd met K-bemesting, maar dat dit moet worden 
toegeschreven aan de hogere opbrengst, niet aan een verlaagde ET. Dit weerspiegelt de watergebruiksefficiëntie, berekend op basis van de korrel. Daarentegen toonden gasuitwisselingsmetingen dat er geen effect is van de water- of K-voorziening op de efficiëntie van het watergebruik. Martineau et al. (2017, blz. 69) stellen dat een goede K-voorziening de planten niet alleen in staat stelt de ET te verminderen door een betere regulatie van het afsluiten van de huidmondjes, maar dat het tegelijkertijd ook leidt tot een groter bladoppervlak, waardoor de ET op plantbasis toeneemt. Verder stelt Martineau et al. (2017) dat K-bemesting leidend tot een groter bladoppervlak bij een slechte vochtvoorziening ook tot meer schade kan leiden. In Figuur 17 zijn conceptueel de processen weergegeven hoe een plant reageert op $\mathrm{K}$ en op water tekort.

Martineau et al. (2017, blz. 69) namen meer opkrullen waar bij voldoende K-voeding en een watertekort, wat leidde tot een lagere ET en fotosynthese. Andere auteurs rapporteerden daarentegen minder opkrullen (Premachandra et al., 1993 geciteerd door Martineau et al. 2017, blz. 69). Volgens Martineau et al. (2017) kan dit te wijten zijn aan een ander gedrag van verschillende cultivars. Ondanks waarnemingen van een niet-substantieel verlaagde ET bij K-bemesting in veldexperimenten (Martineau et al. 2017, blz. 69) zijn de hier geciteerde auteurs het er over eens dat kaliumbemesting moet worden beschouwd als een strategie voor aanpassing aan klimaatverandering om de droogtetolerantie van planten te verhogen. Martineau et al. 2017. (blz. 69) geeft in zijn publicatie bijvoorbeeld aan dat indien droogte een beperking vormt voor de groei de watergehaltes in maïsplanten dat deze bij een goede voorziening geringer worden verlaagd dan bij K-deficiënte planten (met ook opbrengstvermindering, vermindering van graanvulling en minder bestuiving).

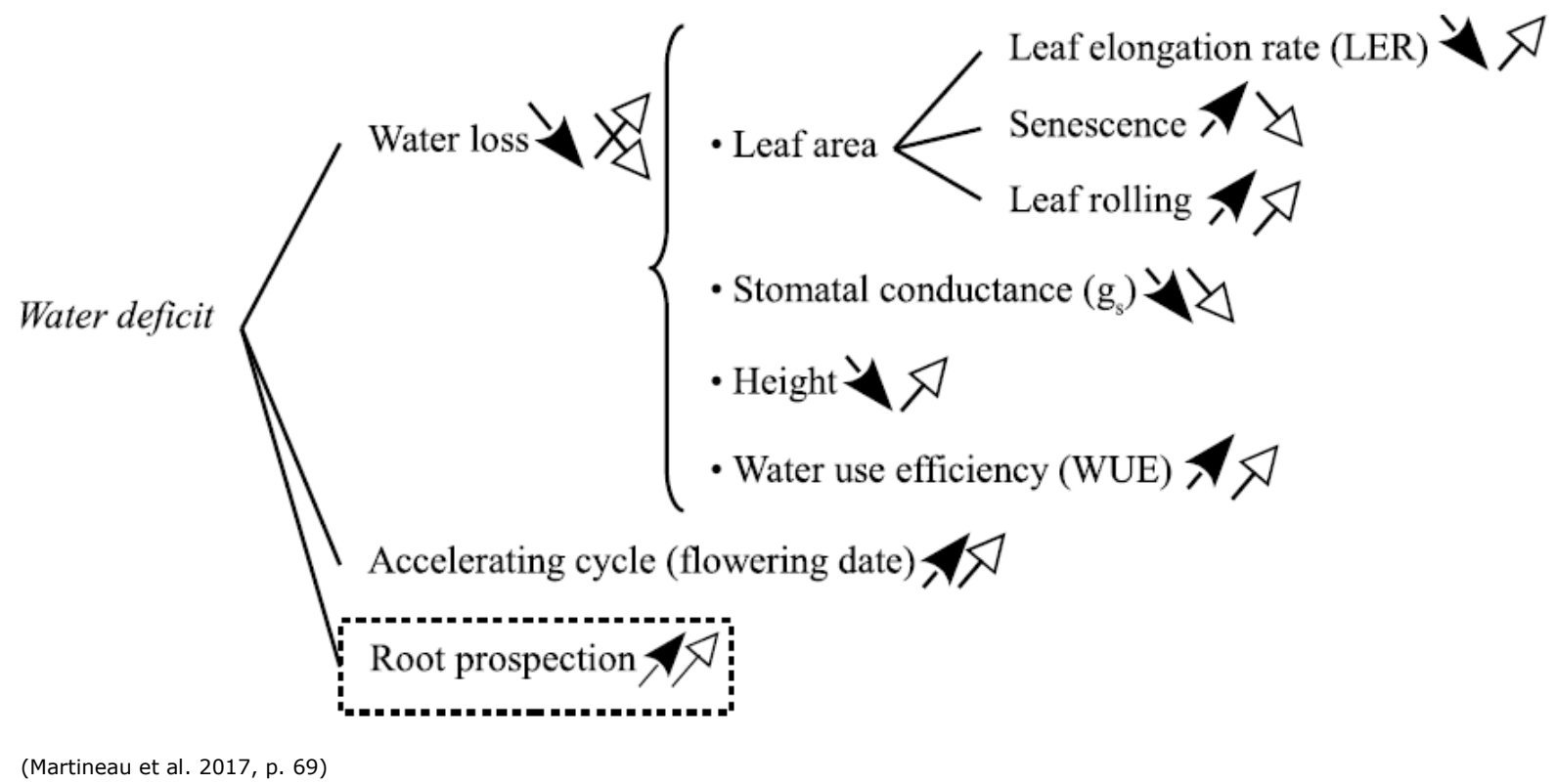

Figuur 17 Conceptueel model van de plantreactie op kaliumvoeding bij watertekort. De donkere en witte pijlen vertegenwoordigen de gevolgen van respectievelijk watertekort en optimale kaliumvoeding, Pijlen naar boven betekenen dat de factor is verbeterd, en vice versa. Gekruiste pijlen betekenen dat het kalium effect niet duidelijk is vastgesteld. De bekende maar niet-gemeten effecten van kalium zijn vertegenwoordigd in het gestippelde vierkant (overgenomen uit Martineau et al. 2017, p. 69).

In onze proeven deed zich een opvallend feit voor en wel dat de hoogste drogestofpercentages bij de oogst samenvielen met de laagste K-gehalten in de drogestof en dat deze ook gepaard lijken te gaan met de hoogste drogestofopbrengsten. Het lijkt erop dat hoge K-gehalten in de drogestof de afrijping van de mais vertragen. Het gewas blijft langer groen. Voedertechnisch lijkt er geen voordeel te zijn van langer groen blijven cq. van een lager drogestofgehalte (door hogere K-bemesting) zo blijkt uit de analyse van de voederwaarde (VEM en zetmeel) in de detailproef. Een hoog kaligehalte en dus een hoge kalibemesting en of K-toestand in de drogestof kan volgens Martineau (et al., 2017) zelfs nadelig zijn voor de opbrengst in situaties van waterstress (zie figuur 17). Een opbrengstdaling bij hoge Ktoestanden en of bemestingen lijkt ook op te treden in de door ons uitgevoerde proeven in de analyse van de miniproeven en de detailproeven tezamen (figuur 11). Hoewel een modelartefact niet kan 
worden uitgesloten is het wel opvallend dat in de meta-analyse van Jiang et al. (2018) ook heel duidelijk naar voren komt dat bemesting boven het advies (onttrekking) leidt tot lagere opbrengsten (figuur 18). Het betreft proeven die zijn uitgevoerd in NO China op kleigronden met een Kuitwisselbaar variërend tussen 87 en $135 \mathrm{mg} \mathrm{K}_{2} \mathrm{O} \mathrm{kg}{ }^{-1}$ (gemiddeld 107) met een gemiddelde maandelijkse neerslag van $109 \mathrm{~mm}$. De korrelopbrengst bedraagt gemiddeld zo'n 12 ton per ha bij een bemestingsniveau van $120-150 \mathrm{~kg} \mathrm{~K}_{2} \mathrm{O} \mathrm{ha}{ }^{-1}$. Bij een bemestingsniveau $50 \%$ boven het advies is de opbrengst significant lager (ongeveer 1 ton ha-1). Deze gegevens tezamen met onze gegevens pleiten ervoor om juist niet te veel kali te bemesten. Bij een relatief hoge toestand is bemesten boven de onttrekking nadelig voor de opbrengst.

NB: Uit de gegevens van Herrman et al. (2014) kan dat niet worden afgeleid daar deze proeven bij zeer lage kalitoestanden zijn uitgevoerd.
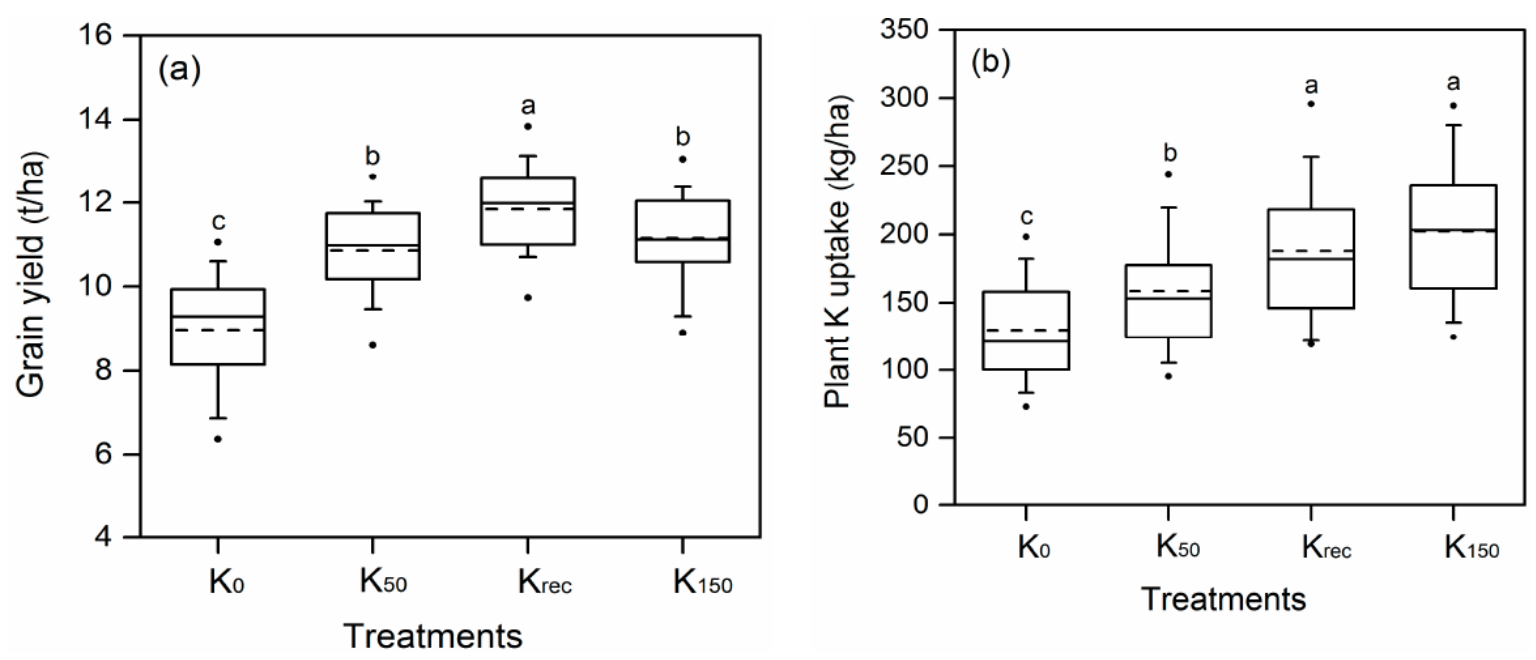

Figuur 18 Korrelopbrengst (a) en plant K-opname (b) voor maïs bij vier verschillende $K$ behandelingen (KO, K50, Krec en K150 met respectievelijk 0, 60-75, 120-150 en 180$225 \mathrm{~kg} \mathrm{~K}_{2} \mathrm{O} \mathrm{ha}{ }^{-1}$ ) over 60 locaties. Zwarte vaste en gestippelde lijnen vertegenwoordigen respectievelijk de mediaan en gemiddelde waarden, de bovenste en onderste van de box randen vertegenwoordigen de $25 \%$ en $75 \%$ kwartielen; de kappen van de whisker vertegenwoordigen de $90 \%$ en $10 \%$ percentielen vermelden; en cirkels duiden de $95 \%$ en $5 \%$ percentielen aan. Kleine letters duiden op een significant verschil $(p<0,01)$ tussen de vier behandelingen (Jiang et al., 2018).

\subsection{Naar een K-bemestingsadvies}

Een K-bemestingsadvies mede gebaseerd op onttrekking is gewenst om te voorkomen dat gronden op termijn worden uitgemijnd bij lage kaligiften. Daarbij kan uitgegaan worden van een kritische $\mathrm{K}$ gehalte $8,0-8,5 \mathrm{mg} \mathrm{kg}^{-1}$. Hoewel kali een belangrijke rol speelt met betrekking tot het verminderen van droogtestress zijn er geen aanwijzingen dat hiervoor duidelijk hogere gehalten dan $8,0-8,5 \mathrm{mg} \mathrm{kg}^{-1}$ nodig zijn in de drogestof en uit het voorgaande lijkt een hoge kaligift eerder nadelig dan voordelig te werken op de opbrengst. Er zijn 3 mogelijkheden voor een advies:

1. Bemesten op onttrekking

2. Bemesten op onttrekking en rekening houdend met de bodemtoestand via $\mathrm{K}-\mathrm{CaCl}_{2}$. $\mathrm{Bij}$ waarden boven een zekere streeftoestand wordt er gekort en bij waarden onder de streeftoestand wordt er extra gegeven. Op termijn wordt zo de streeftoestand gerealiseerd.

3. Bemesten op onttrekking en rekening houdend met de bodemtoestand via $\mathrm{K}-\mathrm{CaCl}_{2}$ en $\mathrm{CEC}$

Ad 1). Bij alleen bemesten op onttrekking kan grondonderzoek achterwege blijven. Tegelijk betekent het dat percelen met een hoge toestand met kali bemest worden terwijl ze dat eigenlijk niet nodig hebben. Op basis van de voorhanden informatie lijkt dat eerder nadelig dan voordelig uit te pakken voor de opbrengst. 
Ad 2) In de proeven werd tot een $\mathrm{K}-\mathrm{CaCl}_{2}$ van $60 \mathrm{mg} \mathrm{kg}^{-1}$ een opbrengstrespons van kali-bemesting gemeten. Uitgangspunt voor het bemestingsadvies op onttrekking kan zijn een kritisch K-gehalte 8,3 $\mathrm{mg} \mathrm{kg}^{-1}$ ofwel $10 \mathrm{mg} \mathrm{K}_{2} \mathrm{O} \mathrm{kg}{ }^{-1}$ met een streeftoestand voor $\mathrm{K}-\mathrm{CaCl}_{2}$ van $60 \mathrm{mg} \mathrm{kg}^{-1}$. Dit kan leiden tot de volgende formules:

$\mathrm{K}_{2} \mathrm{O}-$ gift $=10 *$ Dsopbrengst (ton per ha) $-\mathrm{a} *\left(\mathrm{~K}-\mathrm{CaCl}_{2}-60\right)$ )

Of tot:

- bij $\mathrm{K}-\mathrm{CaCl}_{2}$ van $<60 \mathrm{mg} \mathrm{kg}{ }^{-1}: \mathrm{K}_{2} \mathrm{O}$-gift= $10 *$ Dsopbrengst (ton per ha)

- $\quad$ bij $\mathrm{K}-\mathrm{CaCl}_{2}$ van $>60 \mathrm{mg} \mathrm{kg}{ }^{-1}: \mathrm{K}_{2} \mathrm{O}$-gift= $10 *$ Dsopbrengst (ton per ha) $-\mathrm{a} *\left(\mathrm{~K}-\mathrm{CaCl}_{2}-60\right)$ )

waarbij a 2 of 3 is.

In tabel 25 en 26 is weergegeven hoe het advies er uitziet bij de verschillende opbrengstniveaus.

Tabel 25 Een conceptadvies voor kali gebaseerd op vergelijking 5 en 6 met a =2.

\begin{tabular}{|c|c|c|c|c|c|c|}
\hline $\mathrm{K}-\mathrm{CaCl}_{2}$ & \multicolumn{3}{|c|}{ via vergelijking 5} & \multicolumn{3}{|c|}{ via vergelijking 6} \\
\hline $\mathrm{mg} \mathrm{kg}^{-1}$ & \multicolumn{3}{|c|}{ ton ds ha-1 } & \multicolumn{3}{|c|}{ ton ds ha-1 } \\
\hline 20 & 280 & 240 & 200 & 200 & 160 & 120 \\
\hline 40 & 240 & 200 & 160 & 200 & 160 & 120 \\
\hline 80 & 160 & 120 & 80 & 160 & 120 & 80 \\
\hline 100 & 120 & 80 & 40 & 120 & 80 & 40 \\
\hline 120 & 80 & 40 & 0 & 80 & 40 & 0 \\
\hline
\end{tabular}

Tabel 26 Een conceptadvies voor kali gebaseerd op vergelijking 5 en 6 met $a=3$.

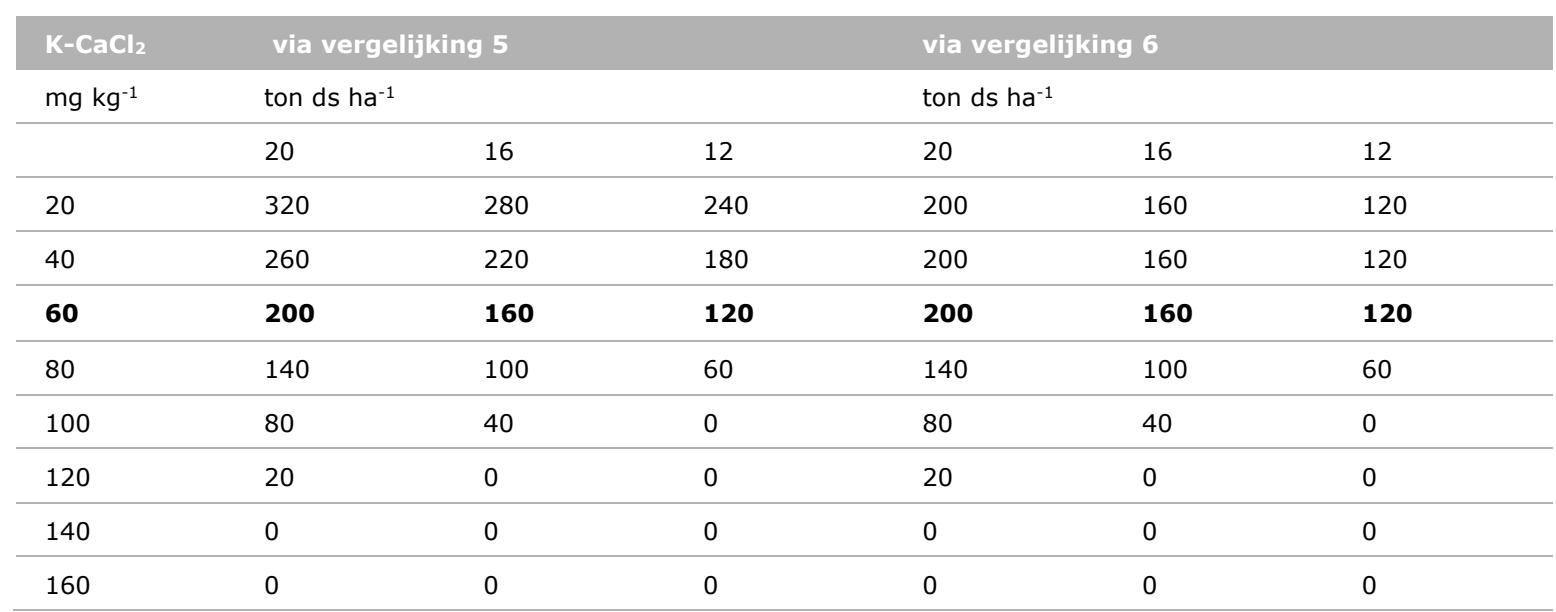

Op basis van vergelijking 5 wordt er bij toestanden beneden de streeftoestand $\left(\mathrm{K}-\mathrm{CaCl}_{2}<60\right)$ bovenop de onttrekking extra kali gegeven en wel meer naarmate de toestand lager is en a hoger (tabel 25 en 26). Bij waarden boven de streeftoestand wordt er gekort omdat de bodem veel na kan leveren. Hoewel systematiek 2 veel gebruikt wordt in de bemestingsadvisering van andere nutriënten is er voor de kaliadvisering van mais geen reden om extra $\mathrm{K}$ te geven bij lage toestanden. Onze proeven wijzen uit dat zelfs bij lage toestanden de maximale opbrengst kan worden gerealiseerd, zodra de bemesting hoger is dan $50-100 \mathrm{~kg} \mathrm{~K}{ }_{2} \mathrm{O} / \mathrm{ha}$. Bemesting op onttrekking volstaat voor maximale opbrengst en het niet verder dalen van de K-toestand. Boven de streeftoestand is korten wel 
wenselijk. Zonder kalibemesting kan de maximale opbrengst worden gerealiseerd. Bovendien kan kali relatief gemakkelijk uitspoelen zeker in natte winters. Met een waarde 3 voor a (tabel 26) vindt een sterkere afbouw plaats dan bij a is 2 (tabel 25). Bij een waarde $a=2$ wordt er uitgegaan van een bouwvoordikte van $25-30 \mathrm{~cm}$. Bij een bouwvoordikte van $25-30 \mathrm{~cm}$ en een bulkdichtheid van $1300-$ $1400 \mathrm{~kg} / \mathrm{m} 3 \mathrm{komt} 10 \mathrm{mg} \mathrm{K}-\mathrm{CaCl}_{2} \mathrm{mg} / \mathrm{kg}$ overeen met $40-50 \mathrm{~kg} \mathrm{~K}{ }_{2} \mathrm{O}$ per ha. $\mathrm{Bij}$ een $\mathrm{K}-\mathrm{CaCl}_{2}$ van 140 kan er 320-400 kg worden nageleverd voordat $\mathrm{K}-\mathrm{CaCl}_{2}$ een waarde van 60 wordt bereikt (indien er nalevering vanuit diepere lagen plaatsvindt). Bij een opbrengst van 20 ton ds/ha is dit gelijk aan een onttrekking van 1,5-twee jaar maisgroei. $\mathrm{Bij}$ een $\mathrm{K}-\mathrm{CaCl}_{2}$ van 100 is dat $160-200 \mathrm{~kg}$ voordat $\mathrm{K}-\mathrm{CaCl}_{2}$ een waarde van 60 wordt bereikt. In combinatie met een adviesgift van 80 (bij a=3) komt dit ook overeen met een onttrekking van 1,5-twee jaar maisgroei.

Een advies moet 4 jaar geldig zijn. Bekend is dat ook uit diepere lagen $\mathrm{K}$ nageleverd kan worden. Verder is het uiterst onwaarschijnlijk dat maispercelen gedurende 4 jaar geen dierlijke mest krijgen. In veel gevallen zal de bemesting met kali uit mest substantieel zijn. Dat betekent dat er geen aanleiding is om na 2 jaar over te schakelen op een advies dat gelijk is aan de gewasonttrekking omdat $\mathrm{K}-\mathrm{CaCl}_{2}$ dan gedaald zou zijn tot 60 of lager. Een nog sterkere afbouw van de K-gift is mogelijk. Op basis van de ontwikkeling van de K-toestanden de komende jaren zou daartoe kunnen worden besloten.

Vergelijken we het bovenstaande met het huidige gewasadvies tot en met 2018 voor een situatie met $3.2 \%$ os en zandgrond dan komt een:

- $\quad \mathrm{K}$-getal van 11 (advies is dan 300) overeen met een $\mathrm{K}-\mathrm{HCl}$ waarde van $11 *(10+3) / 20=7,15 \mathrm{mg}$ $\mathrm{K}_{2} \mathrm{O} 100 \mathrm{~g}^{-1}$ ofwel $60 \mathrm{mg} \mathrm{K} \mathrm{kg}{ }^{-1}$

- $\quad \mathrm{K}$-getal van 24 (advies is dan 0) overeen met een $\mathrm{K}-\mathrm{HCl}$ waarde van $132 \mathrm{mg} \mathrm{K} \mathrm{kg}{ }^{-1}$

Ter vergelijk bij opbrengsten van 20, 16 en 12 ton ds/ha wordt het advies 0 bij $\mathrm{K}-\mathrm{CaCl}_{2}$ waarden van resp 126, 113 en $100 \mathrm{mg} \mathrm{K} / \mathrm{kg}$.

Ad 3) Uitgangspunt was om een advies te ontwikkelen op basis van $\mathrm{K}-\mathrm{CaCl}_{2}$ en $\mathrm{CEC}$. Bij een hoge $\mathrm{CEC}$ wordt $\mathrm{K}$ sterker gebufferd dan bij een lage $\mathrm{CEC}$. Bij een hoge $\mathrm{CEC}$ en een lage $\mathrm{K}-\mathrm{CaCl}_{2}$ zou dan mogelijk meer $\mathrm{K}$ nodig zijn om eenzelfde opbrengstrespons te generen. Uit onze proeven is niet gebleken dat de CEC op deze manier van invloed is op de opbrengst (er was ook geen effect tussen $\mathrm{K}$ bemesting en $\mathrm{CEC}$ ). Wel was er een effect op $\mathrm{K}$-opbrengst en $\mathrm{K}$-gehalte. Zo is volgens figuur 12 het $\mathrm{K}$ gehalte bij een CEC van 200 duidelijk lager dan bij een CEC van 40 bij eenzelfde $\mathrm{K}-\mathrm{CaCl}_{2}$. Tegelijk is het effect van bemesting op het K-gehalte bij een hoge CEC veel kleiner dan bij een lage CEC (dat zien we bij de rivierklei in de detailproef te Wageningen met een K-gehalte van 7).

Corrigeren voor de CEC is mogelijk maar arbitrair. De formule kan er als volgt uit zien:

- bij $\mathrm{K}-\mathrm{CaCl}_{2}$ van $<60 \mathrm{mg} \mathrm{kg}^{-1}$

$\mathrm{K}_{2} \mathrm{O}-\mathrm{gift}=10 *$ Dsopbrengst $($ ton $/ \mathrm{ha})+60 \_$CEC100_200 +120_CEC $>200$

- $\quad$ bij $\mathrm{K}-\mathrm{CaCl}_{2}$ van $>60 \mathrm{mg} \mathrm{kg}^{-1}$ :

$\mathrm{K}_{2} \mathrm{O}-\mathrm{gift}=7 \mathrm{a}-\mathrm{a} *\left(\mathrm{~K}-\mathrm{CaCl}_{2}-60\right)$

Tabel 27 Een conceptadvies voor kali gebaseerd op vergelijking $7 a$ en $7 b$ met $a=3$ en $\mathrm{K}-\mathrm{CaCl}_{2}$ streefwaarde van respectievelijk 60, 80 en 100 voor CEC<100, 100-200, >200.

\begin{tabular}{|c|c|c|c|c|c|c|c|c|c|c|}
\hline $\mathrm{K}-\mathrm{CaCl}_{2}$ & \multicolumn{3}{|c|}{$C E C<100$} & \multicolumn{3}{|c|}{ CEC100-200 } & \multicolumn{4}{|c|}{$C E C>200$} \\
\hline $\mathrm{mg} \mathrm{kg}^{-1}$ & 20 & 16 & 12 & 20 & 16 & 12 & & 20 & 16 & 12 \\
\hline 20 & 200 & 160 & 120 & 200 & 160 & 120 & 200 & & 160 & 120 \\
\hline 40 & 200 & 160 & 120 & 200 & 160 & 120 & 200 & & 160 & 120 \\
\hline 80 & 140 & 100 & 60 & 200 & 160 & 120 & 200 & & 160 & 120 \\
\hline 100 & 80 & 40 & 0 & 140 & 100 & 60 & 200 & & 160 & 120 \\
\hline 120 & 20 & 0 & 0 & 80 & 40 & 0 & 140 & & 100 & 60 \\
\hline 140 & 0 & 0 & 0 & 20 & 0 & 0 & 80 & & 40 & 0 \\
\hline
\end{tabular}


Het effect van extra bemesting bij een hoge CEC is echter zeer beperkt op basis van figuur 13.

Bovendien is er geen duidelijk opbrengst respons aangetoond bij hoge $\mathrm{CEC}$ en relatieve lage $\mathrm{K}-\mathrm{CaCl}_{2}$.

Door sommige auteurs (Khan et al., 2013) wordt zelfs in twijfel getrokken of je gronden met een hoog kleigehalte $(>25 \%)$ en dus een hoge CEC überhaupt wel moet bemesten met $\mathrm{K}$. Uit een lange termijn proef in Amerika en analyse van meer dan 2100 opbrengstresponse studies gaf aan dat $\mathrm{KCl}$-bemesting zelden tot een verhoging van de gewasopbrengst leidt. Het tegendeel is volgens deze auteurs eerder waar; meer dan 1400 van de 2100 proeven lieten een nadelig effect van $\mathrm{KCl}$-bemesting zien op de kwaliteit van de belangrijkste voedsel, diervoeder en vezelgewassen. Opgemerkt dient te worden dat deze locaties veelal kleigronden betrof die vanwege de aanwezige kleimineralen voldoende $K$ kunnen naleveren. Dit kan heel lang doorgaan. Over een periode van 50 jaar kon in het Morrow veldexperiment geen daling van de kaligehalten worden aangetoond bij geen kalibemesting.

Daarom wordt voorgesteld systematiek 3 niet in te voeren en wordt voorgesteld het onderstaande advies in te voeren.

Tabel 28 Een conceptadvies voor kali in $\mathrm{kg} \mathrm{K}_{2} \mathrm{O}$ per ha.

\begin{tabular}{|c|c|c|c|}
\hline $\mathrm{K}-\mathrm{CaCl}_{2}$ & Opbrengst & & \\
\hline 20 & 200 & 160 & 120 \\
\hline 40 & 200 & 160 & 120 \\
\hline 80 & 140 & 100 & 60 \\
\hline 100 & 80 & 40 & 0 \\
\hline 120 & 20 & 0 & 0 \\
\hline
\end{tabular}

\subsection{Kali-bemesting met dierlijke mest en rijenbemesting en magnesium uit bodem en dierlijke mest}

In de detailproef zijn $\mathrm{K}$ uit dierlijk mest vergeleken met kunstmest. Tevens is $\mathrm{K}$-rijenbemesting vergeleken met volveldse K-bemesting.

Zowel bij kunstmest als bij dierlijke mest is slechts in een enkele locatie-jaar combinatie rijenbemesting effectiever dan volveldse bemesting, af te lezen aan de respons van K-opbrengst (tabel 13). In de voorbereidende deskstudie bleek dat er geen recent West-Europees onderzoek bekend is waarbij de efficiëntie van K-rijenbemesting ten opzichte van volveldse toediening is onderzocht. Meer recent onderzoek is vooral Amerikaans onderzoek, veelal met korrelmaïs en bij teeltsystemen met beperkte grondbewerking.

Kalium uit dierlijke mest bleek net zo effectief als uit kunstmest, zowel volvelds als in de rij. Er wordt uitgegaan van een K-werkingscoëfficiënt van 100\%, af te lezen aan K-opbrengst (bijlage 5, tabel 45 en 46).

Uit de analyse blijkt dat magnesiumgift en magnesiumtoestand van invloed is op het kaligehalte. Andersom heeft de K-gift, de K-toestand en de mestgift ook effect op het magnesiumgehalte van mais. In Nederland daalt de mestgift in de praktijk door de verandering in wetgeving. Interessant is dan om na te gaan of de magnesiumvoorziening op basis van alleen mest toereikend is. Dit kan alleen op basis van deze proef niet worden bepaald. 


\subsection{Advies en dierlijke bemesting}

Een van de aanleidingen van het onderzoek was of een hoge kaligift van $300 \mathrm{~kg} \mathrm{~K} \mathrm{~K}_{2} \mathrm{O}$ per ha echt nodig is voor een optimale opbrengst. Door de mestwetgeving wordt de kaligift met mest beperkt vooral bij een fosfaattoestand hoog (tabel 29). Er is dan een aanvulling met kunstmest kali nodig om $300 \mathrm{~kg}$ per ha te kunnen geven. Dit onderzoek geeft aan dat de huidige K-adviezen voor mais te hoog zijn. Verder geeft het onderzoek aan dat er geen significante verschillen zijn in de K-werking van mest en kunstmest. In Tabel 29 is weergegeven welke K-gift met mest ongeveer wordt gegeven bij verschillende giften met dunne rundveemest. Het blijkt dat zelfs bij toestand hoog via mest voldoende kali wordt gegeven. Alleen bij erg hoge maisopbrengsten, 20 ton ds/ha en meer, kan een kleine aanvulling met kunstmest gewenst zijn indien $\mathrm{K}-\mathrm{CaCl}_{2}<60$ is.

Tabel 29 Kali-bemesting met rundveedrijfmest (rdm) bij 3 fosfaatklassen.

\begin{tabular}{llll} 
P klasse & $\mathrm{kg} \mathrm{P} \mathrm{O}_{5} \mathrm{ha}^{-1}$ & $\mathrm{~m}^{3} \mathrm{rdm} \mathrm{ha}$ & $\approx \mathrm{kg} \mathrm{K}_{2} \mathrm{O} \mathrm{ha}$ \\
Laag & 75 & 55 & 297 \\
\hline Neutraal & 60 & 40 & 216 \\
\hline Hoog & 50 & 34 & 184 \\
\hline
\end{tabular}




\section{$7 \quad$ Conclusies en bemestingsadvies}

\section{Conclusies detailproeven}

- K-bemesting had geen effect op de drogestofopbrengst. K-bemesting had wel een positief effect op de vers-opbrengst, het K-gehalte en de K-opbrengst en een negatief effect op het drogestofgehalte.

- $\quad$ In het eerste proefjaar was er op alle drie de locaties een negatief effect van K-bemesting op zetmeelgehalte, in het tweede proefjaar was er geen effect.

- Het toedienen van volvelds drijfmest had, net als kunstmest, vrijwel geen effect op drogestofopbrengst. Alleen op klei in 2015 was er een negatief effect van ca. $700 \mathrm{~kg} \mathrm{ds} / \mathrm{ha}$. Er was een positief effect op de vers-opbrengst, het K-gehalte en de K-opbrengst en een negatief effect op drogestofgehalte.

- $\quad$ Drijfmest in de rij toedienen had een gelijk effect voor K-gehalte en -opbrengst als volvelds drijfmest toedienen.

- Het verlagen van het stikstofniveau van 200 naar $100 \mathrm{~kg} \mathrm{~N} / \mathrm{ha}$ (in 2016 en 2017 uitgevoerd) had op de twee locaties een negatief effect op drogestofopbrengst van ca. $700 \mathrm{~kg} \mathrm{ds} / \mathrm{ha}$ en op ruw eiwitgehalte van 2 tot $3 \mathrm{~g}$ re/kg ds.

- $\quad$ Het effect van rijenbemesting met K-kunstmest verschilde alleen op locatie Vredepeel in 2017 van het effect van volvelds toedienen: de effecten van de K-bemesting met kunstmest op Kgehalte, -opbrengst, vers-opbrengst en drogestofgehalte waren groter wanneer rijenbemesting werd toegepast in plaats van volvelds.

- $\quad$ Er was geen verschil in de grootte van de respons in K-gehalte en K-opbrengst tussen rijenbemesting en volvelds bemesting met drijfmest.

- $\quad$ De respons van $\mathrm{K}$-gehalte en $\mathrm{K}$-opbrengst op de $\mathrm{K}$ uit drijfmest was altijd gelijk of hoger dan de respons op K uit kunstmest. De K-werkingscoëfficiënt van drijfmest was steeds minimaal $100 \%$.

\section{Conclusies detail- en miniproeven samen}

\section{Drogestofopbrengst:}

- $\quad$ K, CEC, de bezetting van het adsorptiecomplex en de (werkzame) K-bemesting waren van invloed op de drogestofopbrengst. In het traject van 20 tot $60 \mathrm{~K}-\mathrm{CaCl}_{2}$ in de bodem was er een positief effect van bemesting dat daalde naar 0 naarmate $\mathrm{K}-\mathrm{CaCl}_{2}$ steeg naar 60 . Daarboven was er geen effect meer van K-bemesting op de opbrengst.

- De maximale opbrengst was te verkrijgen door een $\mathrm{K}$-bemestingshoeveelheid die veel kleiner was dan de gewasonttrekking (40-80 $\left.\mathrm{kg} \mathrm{K}_{2} \mathrm{O} \mathrm{ha}{ }^{-1}\right)$. Waarschijnlijk laat zich dat verklaren door $\mathrm{K}$-nalevering uit diepere bodemlagen en dat het gewas steeds dieper wortelt bij verdere groei.

\section{K-gehalte:}

- De kaligift, $\mathrm{K}-\mathrm{CaCl}_{2}, \mathrm{CEC}$, magnesiumbemesting en -toestand en hun interacties waren van invloed op het K-gehalte in mais. De relaties zijn complex en zijn niet nader geduid.

- De experimenten gaven een kritisch $\mathrm{K}$-gehalte van ongeveer 8,0-8,5 g K kg-1. Deze waarde stemt goed overeen met waarden in literatuur. Er wordt in de oudere literatuur echter ook een hogere waarde als een indicator voor een adequate K-voorziening voorgesteld van $13 \mathrm{~g}$ $\mathrm{kg}^{-1} \mathrm{ds}$. Eén van de belangrijke effecten die aan een goede kalivoorziening worden toegeschreven is dat het gewas beter bestand is tegen droogte waardoor het gewas beter kan blijven produceren. Er zijn echter weinig aanwijzingen dat daarvoor echt hoge bemestingen nodig zijn om mais beter resistent te maken tegen droogte. Bovendien bleek uit proeven in literatuur dat kalium het effect van droogtestress niet opheft.

\section{Drogestofpercentage:}

- Opvallend was dat de hoogste drogestofpercentages bij de oogst samenvielen met de laagste $\mathrm{K}$-gehalten in de drogestof en dat deze ook gepaard leken te gaan met de hoogste drogestofopbrengsten. Het lijkt erop dat hoge K-gehalten in de drogestof de afrijping van de mais vertragen. Het gewas blijft langer groen. Voedertechnisch leek er geen voordeel te zijn 
van langer groen blijven cq. van een lager drogestofgehalte (door hogere K-bemesting) zo blijkt uit de analyse van de voederwaarde (VEM en zetmeel) in de detailproef.

\section{K uit kunstmest en drijfmest:}

- Voor het effect van K-bemesting op de opbrengst behoeft geen onderscheid gemaakt te worden tussen kali uit kunstmest en werkzame $\mathrm{K}$ uit rundveemest.

- Op de objecten met drijfmest was, gemiddeld over alle data, de opbrengst 1 ton lager dan op de objecten zonder drijfmest.

\section{Invloed CEC:}

- $\quad$ Bij een hoge CEC was er weinig effect van bemesting op het $\mathrm{K}$-gehalte. Bij een hoge CEC was een veel hogere $\mathrm{K}-\mathrm{CaCl}_{2}$ nodig om eenzelfde $\mathrm{K}$-gehalte en $\mathrm{K}$-opbrengst te realiseren als bij een lage CEC. Ofwel: bij een hoge CEC heeft het gewas een hogere bodemvoorraad nodig en

K-HCl: is de $\mathrm{K}$ uit bemesting minder effectief dan bij een lage CEC.

- Toevoegen van de $\mathrm{K}-\mathrm{HCl}$ analyse, de bodemanalyse waar het $\mathrm{K}$-bemestingsadvies tot nu toe op gebaseerd was, gaf geen betere verklaring van de gewasrespons. Het gebruik van $\mathrm{K}-\mathrm{HCl}$ in plaats van $\mathrm{K}-\mathrm{CaCl}_{2}, \mathrm{CEC}$ en de andere verklarende factoren gaf een slechtere verklaring van de gewasrespons en is dus minder geschikt voor het $\mathrm{K}$-bemestingsadvies.

\section{Lange termijn:}

- $\quad$ Op de lange termijn gezien kan een bemesting van 40-80 $\mathrm{kg} \mathrm{K}_{2} \mathrm{O}$ ha-1 niet toereikend zijn omdat er uitmijning van kali plaatsvindt. Bovendien kan kali op de lichtere gronden gemakkelijk uitspoelen. Daar tegenover staat dat door capillaire opstijging een deel van deze kali alsnog beschikbaar is voor het gewas, vooral in het tweede deel van het groeiseizoen.

\section{K-bemestingsadvies voor snijmaïs}

Tabel 30 Advies kali-bemesting voor snijmaïs, $k g K_{2} O$ per ha.

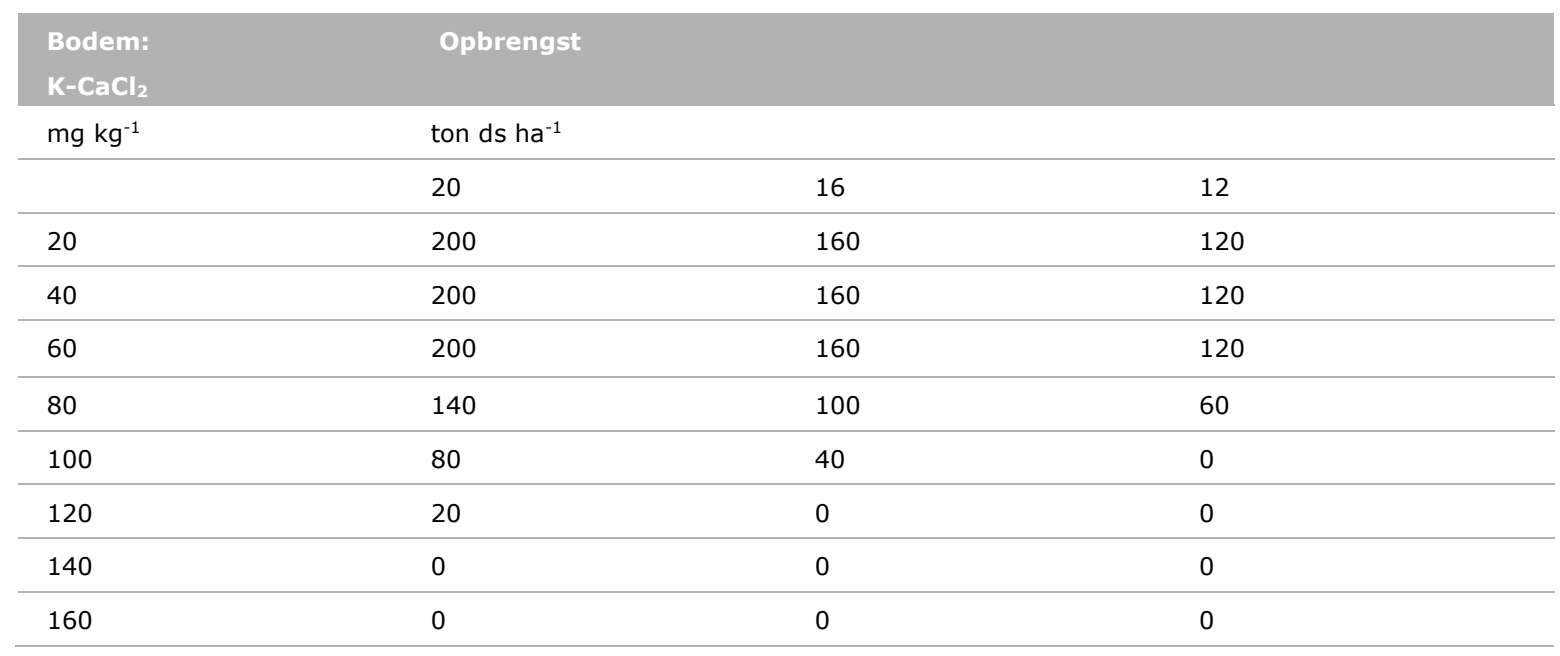




\section{Literatuur}

Hasanuzzaman, Mirza; Bhuyan, M.; Nahar, Kamrun; Hossain, Md.; Mahmud, Jubayer; Hossen, Md. et al. (2018): Potassium. A Vital Regulator of Plant Responses and Tolerance to Abiotic Stresses. In Agronomy 8 (3), p. 31. DOI: 10.3390/agronomy8030031.

Harville, D.A., 1977: Maximum Likelihood Approaches to Variance Component Estimation and to Related Problems. Journal of the American Statistical Association 72 (358): 320-338.

Herrmann, A., Schröder, F., Kluß, C., Lausen, P., Techow, E., Feger.G., Taube, F., 2014: Wie viel Kalium braucht Silomais auf leichten Standorten? Tagungsband der 58. Jahrestagung der Arbeitsgemeinschaft Grünland und Futterbau (AGGF) in der Gesellschaft für Pflanzenbauwissenschaften e.V. in Arnstadt vom 28.-30. August 2014. 116-120.

Jiang, W., Liu, X., Wang, Y., Zhang, Y., Qi, W., 2018:Responses to Potassium Application and Economic Optimum K Rate of Maize under Different Soil Indigenous K Supply. Sustainability 10, 2267; doi:10.3390/su10072267.

Khan, S.A., R.L. Mulvaney and T.R. Ellsworth (2013) .The potassium paradox: Implications for soil fertility, crop production and human health. Renewable Agriculture and Food Systems: 29(1); 3-27

Kovacevic, V., Rastija M., Simic B., Andric, L., Kaucic D., 2008: Phosphorus and potassium fertilization impacts on yield and nutritional status of maize. In:VI Alps-Adria Workshop. Stara Lesna, Slovakia 2008. 43-46.

Leigh, R.A., Wyn Jones, R.G., 1984: A Hypothesis Relating Critical Potassium Concentrations for Growth to the Distribution and Functions of this Ion in the Plant Cell. New Phytologist, Vol. 97, No. 1 , pp. 1-13.

Martineau, Elsa; Domec, Jean-Christophe; Bosc, Alexandre; Denoroy, Pascal; Fandino, Véronica Asensio; Lavres, José; Jordan-Meille, Lionel (2017): The effects of potassium nutrition on water use in field-grown maize (Zea mays L.). In Environmental and Experimental Botany 134, pp. 62-71. DOI: $10.1016 /$ j.envexpbot.2016.11.004.

Prummel, J., 1966: De fosfaat- en kalibemesting van maïs. De Buffer 12, p.46-49.

Subedi, K.D., Ma, B.L., 2009 : Assessment of some major yield-limiting factors on maize production in a humid temperate environment. Field Crops Research 110 (2009) 21-26.

Van Rotterdam-Los, A.M.D., 2010: The potential of soils to supply phosphorus and potassium; processes and predictions. PhD thesis Wageningen University, pp 141.

Van Schooten, H.A., Van Schöll, L., Van Dijk, W., Van Middelkoop, J.C., Den Boer, D.J., 2011: Doeltreffend kali-bemestingsadvies voor snijmaïs; Literatuurstudie naar achtergronden en verbeteringen van huidig advies. Rapport 500. Wageningen UR Livestock Research, Lelystad. 


\section{Bijlage 1 Proefveldschema's}

Proefveldschema Marwijksoord 2015

\begin{tabular}{|c|c|c|c|c|c|c|c|c|c|c|c|c|}
\hline & 1 & ODm & $\mathrm{OK}$ & 1 & 8 & ODm & $320 \mathrm{KBw}$ & 1 & 15 & 20DmR & 40KRij & 1 \\
\hline & 2 & 20DmV & $80 \mathrm{KRij}$ & 1 & 9 & 20DmV & 40KRij & 1 & 16 & 20DmV & OK & 1 \\
\hline \multirow[t]{7}{*}{ I } & 3 & 20DmR & $80 \mathrm{KBw}$ & 1 & 10 & ODm & $40 \mathrm{KBw}$ & 1 & 17 & ODm & 40KRij & 1 \\
\hline & 4 & ODm & 160KRij & 1 & 11 & 20DmR & $40 \mathrm{KBw}$ & 1 & 18 & ODm & $80 \mathrm{KRij}$ & 1 \\
\hline & 5 & 20DmV & $160 \mathrm{KRij}$ & 1 & 12 & ODm & $160 \mathrm{KBw}$ & 1 & 19 & 20DmR & $80 \mathrm{KRij}$ & 1 \\
\hline & 6 & 20DmV & $40 \mathrm{KBw}$ & 1 & 13 & 20DmV & $160 \mathrm{KBw}$ & 1 & 20 & $20 \mathrm{DmV}$ & $80 \mathrm{KBw}$ & 1 \\
\hline & 7 & ODm & $80 \mathrm{KBw}$ & 1 & 14 & 20DmR & $\mathrm{OK}$ & 1 & 33 & ODm & $80 \mathrm{KRij}$ & 2 \\
\hline & 21 & 20DmV & $40 \mathrm{KBw}$ & 2 & 27 & 20DmV & $80 K B w$ & 2 & 34 & ODm & $160 \mathrm{KBw}$ & 2 \\
\hline & 22 & ODm & 160KRij & 2 & 28 & 20DmR & 40KRij & 2 & 35 & 20DmV & $160 \mathrm{KBw}$ & 2 \\
\hline \multirow[t]{7}{*}{ II } & 23 & ODm & $320 \mathrm{KBw}$ & 2 & 29 & ODm & 40KRij & 2 & 36 & ODm & OK & 2 \\
\hline & 24 & 20DmR & $40 \mathrm{KBw}$ & 2 & 30 & 20DmR & $80 \mathrm{KBw}$ & 2 & 37 & 20DmV & $\mathrm{OK}$ & 2 \\
\hline & 25 & 20DmV & 40KRij & 2 & 31 & 20DmV & 160KRij & 2 & 38 & 20DmV & $80 \mathrm{KRij}$ & 2 \\
\hline & 26 & ODm & $40 \mathrm{KBw}$ & 2 & 32 & 20DmR & $80 \mathrm{KRij}$ & 2 & 39 & ODm & $80 \mathrm{KBw}$ & 2 \\
\hline & 41 & 20DmV & 40KRij & 3 & 48 & ODm & 80KRij & 3 & 40 & 20DmR & OK & 2 \\
\hline & 42 & 20DmR & $80 \mathrm{KRij}$ & 3 & 49 & 20DmV & $40 \mathrm{KBw}$ & 3 & 55 & ODm & $320 \mathrm{KBw}$ & 3 \\
\hline & 43 & 20DmV & $\mathrm{OK}$ & 3 & 50 & ODm & $80 \mathrm{KBw}$ & 3 & 56 & 20DmR & $80 \mathrm{KBw}$ & 3 \\
\hline \multirow[t]{7}{*}{ III } & 44 & ODm & $40 \mathrm{KBw}$ & 3 & 51 & 20DmV & $160 \mathrm{KBw}$ & 3 & 57 & 20DmV & 160KRij & 3 \\
\hline & 45 & 20DmR & 40KRij & 3 & 52 & 20DmV & $80 \mathrm{KRij}$ & 3 & 58 & 20DmR & $40 \mathrm{KBw}$ & 3 \\
\hline & 46 & 20DmR & $\mathrm{OK}$ & 3 & 53 & ODm & OK & 3 & 59 & 20DmV & $80 \mathrm{KBw}$ & 3 \\
\hline & 47 & ODm & $160 \mathrm{KBw}$ & 3 & 54 & ODm & $160 \mathrm{KRij}$ & 3 & 60 & ODm & 40KRij & 3 \\
\hline & 61 & 20DmV & $80 \mathrm{KBw}$ & 4 & 68 & 20DmV & 40KRij & 4 & 75 & ODm & $80 \mathrm{KBw}$ & 4 \\
\hline & 62 & ODm & $80 \mathrm{KRij}$ & 4 & 69 & ODm & 40KRij & 4 & 76 & $20 \mathrm{DmV}$ & OK & 4 \\
\hline & 63 & 20DmV & $40 \mathrm{KBw}$ & 4 & 70 & 20DmV & $80 K R i j$ & 4 & 77 & 20DmV & 160KRij & 4 \\
\hline \multirow[t]{4}{*}{ IV } & 64 & 20DmV & $160 \mathrm{KBw}$ & 4 & 71 & ODm & $40 K B w$ & 4 & 78 & ODm & $320 \mathrm{KBw}$ & 4 \\
\hline & 65 & ODm & $160 \mathrm{KBw}$ & 4 & 72 & 20DmR & 40KRij & 4 & 79 & ODm & $\mathrm{OK}$ & 4 \\
\hline & 66 & ODm & $160 \mathrm{KRij}$ & 4 & 73 & 20DmR & $80 \mathrm{KBw}$ & 4 & 80 & 20DmR & $80 \mathrm{KRij}$ & 4 \\
\hline & 67 & 20DmR & $\mathrm{OK}$ & 4 & 74 & 20DmR & $40 \mathrm{KBw}$ & 4 & & & & \\
\hline
\end{tabular}

Proefveldschema Vredepeel 2015

\begin{tabular}{|c|c|c|c|c|c|c|c|c|c|c|c|c|c|c|}
\hline & $6120 \mathrm{DmV}$ & $\mathrm{OK}$ & 1 & 41 & 20DmR & $40 K B w$ & 1 & 21 20DmV & $160 \mathrm{KBw}$ & 1 & & ODm & $\mathrm{OK}$ & 1 \\
\hline & $620 \mathrm{Dm}$ & 40KRij & 1 & & $0 \mathrm{Dm}$ & $160 \mathrm{KBw}$ & 1 & $220 \mathrm{Dm}$ & $80 \mathrm{KBw}$ & 1 & & $20 \mathrm{DmV}$ & $80 K R i j$ & 1 \\
\hline \multirow[t]{5}{*}{ I } & 63 0Dm & $80 \mathrm{KRij}$ & 1 & 43 & $20 \mathrm{DmV}$ & $40 K B w$ & 1 & $230 \mathrm{Dm}$ & $320 \mathrm{KBw}$ & 1 & & 20DmR & $80 K B w$ & 1 \\
\hline & 64 20DmR & $80 K R i j$ & 1 & 44 & 20DmR & $\mathrm{OK}$ & 1 & $2420 \mathrm{DmV}$ & 40KRij & 1 & & t 0Dm & 160KRij & 1 \\
\hline & $6520 \mathrm{DmV}$ & $80 K B w$ & 1 & 45 & 20DmR & 40KRij & 1 & 25 0Dm & $40 \mathrm{KBw}$ & 1 & & $20 \mathrm{DmV}$ & 160KRij & 1 \\
\hline & 66 0Dm & $\mathrm{OK}$ & 2 & 46 & $20 \mathrm{DmV}$ & $160 \mathrm{KBw}$ & 2 & 26 20DmR & $80 \mathrm{KBw}$ & 2 & & $20 \mathrm{DmV}$ & $40 \mathrm{KBw}$ & 2 \\
\hline & $6720 \mathrm{DmV}$ & 40KRij & 2 & 47 & 20DmR & $80 \mathrm{KRij}$ & 2 & $2720 \mathrm{DmV}$ & $80 \mathrm{KBw}$ & 2 & 7 & oDm & $160 \mathrm{KRij}$ & 2 \\
\hline \multirow{3}{*}{ II } & $7020 \mathrm{DmR}$ & $\mathrm{OK}$ & 2 & 50 & $20 \mathrm{DmV}$ & 160KRij & 2 & 30 0Dm & $40 \mathrm{KBw}$ & 2 & 10 & $20 \mathrm{DmV}$ & $\mathrm{OK}$ & 2 \\
\hline & 71 20DmR & $80 \mathrm{KBw}$ & 3 & 51 & ODm & $320 \mathrm{KBw}$ & 3 & 31 20DmR & $\mathrm{OK}$ & 3 & 11 & $20 \mathrm{DmV}$ & 40KRij & 3 \\
\hline & 72 20DmV & 160KRij & 3 & 52 & $20 \mathrm{DmV}$ & $80 K R i j$ & 3 & $320 \mathrm{Dm}$ & $160 \mathrm{KBw}$ & 3 & 12 & 2 20DmR & 80KRij & 3 \\
\hline \multirow[t]{2}{*}{ III } & 73 20DmR & $40 \mathrm{KBw}$ & 3 & 53 & ODm & OK & 3 & 33 0Dm & $80 \mathrm{KRij}$ & 3 & 13 & $320 \mathrm{DmV}$ & $\mathrm{OK}$ & 3 \\
\hline & 74 20DmV & $80 K B w$ & 3 & 54 & ODm & 160KRij & 3 & $3420 \mathrm{DmV}$ & $40 K B w$ & 3 & 14 & $40 \mathrm{Dm}$ & $40 \mathrm{KBw}$ & 3 \\
\hline \multirow{2}{*}{ IV } & 79 0Dm & $\mathrm{OK}$ & 4 & 59 & $20 \mathrm{DmR}$ & $40 \mathrm{KBw}$ & 4 & 39 0Dm & 40KRij & 4 & 19 & $20 \mathrm{DmV}$ & $160 \mathrm{KBw}$ & 4 \\
\hline & 80 20DmR & $80 \mathrm{KRij}$ & 4 & 60 & $0 \mathrm{Dm}$ & $80 \mathrm{KBw}$ & 4 & $4020 \mathrm{DmV}$ & $80 \mathrm{KRij}$ & 4 & 20 & $0 \mathrm{Dm}$ & $160 \mathrm{KBw}$ & 4 \\
\hline
\end{tabular}

$\mathrm{Dm}=$ drijfmest $\mathrm{R}=$ Rijenbemesting $\mathrm{V}=$ Volveldse bemesting $\mathrm{K}=\mathrm{K} 2 \mathrm{O} \mathrm{Bw}=$ Breedwerpig

Rij=Rijenbemesting $\mathrm{N}=$ stikstofbemesting 


\begin{tabular}{|c|c|c|c|c|c|c|c|c|c|c|c|}
\hline & 1 & $20 \mathrm{DmV}$ & $160 \mathrm{KBw}$ & & 29 & $20 \mathrm{DmV}$ & $160 K R i j$ & & 56 & $20 \mathrm{DmV}$ & $80 \mathrm{KBw}$ \\
\hline & 2 & Geen & 160KRij & & 30 & Geen & $80 K B w$ & & 57 & Geen & $80 K R i j$ \\
\hline & 3 & $20 \mathrm{DmR}$ & $80 \mathrm{KBW}$ & & 31 & $20 \mathrm{DmR}$ & 80KRï̈ & & 58 & $20 \mathrm{DmR}$ & OK \\
\hline & 4 & $20 \mathrm{DmV}$ & $80 \mathrm{KBw}$ & & 32 & $20 \mathrm{DmV}$ & $40 \mathrm{KBw}$ & & 59 & $20 \mathrm{DmV}$ & $40 \mathrm{KBw}$ \\
\hline & 5 & Geen & $80 K R i j$ & & 33 & Geen & 40KBw & & 60 & Geen & $320 \mathrm{KBw}$ \\
\hline & 6 & Geen & OK & & 34 & Geen & $160 \mathrm{KBw}$ & & 61 & Geen & $80 \mathrm{KBw}$ \\
\hline & 7 & $20 \mathrm{DmV}$ & 40KRij & & 35 & $20 \mathrm{DmV}$ & $80 \mathrm{KBw}$ & & 62 & $20 \mathrm{DmV}$ & $160 \mathrm{KRij}$ \\
\hline & 8 & $20 \mathrm{DmR}$ & $40 \mathrm{KBW}$ & & 36 & $20 \mathrm{DmR}$ & $80 \mathrm{KBW}$ & & 63 & $20 \mathrm{DmR}$ & $80 \mathrm{KBW}$ \\
\hline & 9 & Geen & $320 \mathrm{KBw}$ & & 37 & Geen & $160 \mathrm{KRij}$ & & 64 & Geen & $160 \mathrm{KBw}$ \\
\hline & 10 & $20 \mathrm{DmV}$ & $40 \mathrm{KBw}$ & 113 & 38 & $20 \mathrm{DmV}$ & $80 \mathrm{KRij}$ & III & 65 & $20 \mathrm{DmV}$ & OK \\
\hline & 11 & $20 \mathrm{DmR}$ & 40KRï & & 39 & $20 \mathrm{DmR}$ & $40 \mathrm{KBW}$ & & 66 & $20 \mathrm{DmR}$ & 80KRï \\
\hline & 12 & Geen & $160 \mathrm{KBw}$ & & 40 & Geen & $\mathrm{OK}$ & & 67 & Geen & 40KRij \\
\hline & 13 & $20 \mathrm{DmV}$ & $\mathrm{OK}$ & & 41 & $20 \mathrm{DmV}$ & $160 \mathrm{KBw}$ & & 68 & $20 \mathrm{DmV}$ & $80 K R i j$ \\
\hline & 14 & $20 \mathrm{DmR}$ & 80KRij & & 42 & $20 \mathrm{DmR}$ & $\mathrm{OK}$ & & 69 & $20 \mathrm{DmR}$ & $40 \mathrm{KBW}$ \\
\hline & 15 & Geen & $40 \mathrm{KBw}$ & & 43 & Geen & $80 K R i j$ & & 70 & Geen & $160 \mathrm{KRij}$ \\
\hline & 16 & $20 \mathrm{DmV}$ & $80 K R i j$ & & 44 & $20 \mathrm{DmV}$ & 40KRij & & 71 & $20 \mathrm{DmV}$ & 40KRij \\
\hline & 17 & Geen & 40KRij & & 45 & Geen & $320 \mathrm{KBw}$ & & 72 & Geen & $40 \mathrm{KBw}$ \\
\hline & 18 & $20 \mathrm{DmR}$ & $\mathrm{OK}$ & & 46 & $20 \mathrm{DmR}$ & 40KRii & & 73 & $20 \mathrm{DmR}$ & 40KRii \\
\hline & 19 & $20 \mathrm{DmV}$ & 160KRij & & 47 & $20 \mathrm{DmV}$ & OK & & 74 & $20 \mathrm{DmV}$ & $160 \mathrm{KBw}$ \\
\hline & 20 & Geen & $80 K B w$ & & 48 & Geen & 40KRij & & 75 & Geen & $\mathrm{OK}$ \\
\hline & 21 & $20 \mathrm{DmV}$ & $\mathrm{OK}$ & & 49 & $20 \mathrm{DmV}$ & 40KRij & & 76 & $20 \mathrm{DmV}$ & $160 \mathrm{KBw}$ \\
\hline & 22 & Geen & $160 \mathrm{KBw}$ & & 50 & Geen & 40KRij & & 77 & Geen & $80 \mathrm{KRij}$ \\
\hline & 23 & $20 \mathrm{DmR}$ & 80KRï & & 51 & $20 \mathrm{DmR}$ & $40 \mathrm{KBW}$ & & 78 & $20 \mathrm{DmR}$ & $\mathrm{OK}$ \\
\hline $\mathrm{IV}$ & 24 & $20 \mathrm{DmV}$ & $40 \mathrm{KBw}$ & & 52 & $20 \mathrm{DmV}$ & $80 \mathrm{KRij}$ & & 79 & $20 \mathrm{DmV}$ & $80 \mathrm{KBw}$ \\
\hline & 25 & Geen & $80 K B w$ & & 53 & Geen & $320 \mathrm{KBw}$ & & 80 & Geen & $40 \mathrm{KBw}$ \\
\hline & 26 & $20 \mathrm{DmR}$ & $80 K B W$ & & 54 & $20 \mathrm{DmR}$ & 40KRij & & & & \\
\hline & 27 & Geen & $\mathrm{OK}$ & & 55 & Geen & 160KRij & & & & \\
\hline & 28 & $20 \mathrm{DmV}$ & 160KRij & & & & & & & & \\
\hline
\end{tabular}

$\mathrm{Dm}=$ drijfmest $\mathrm{R}=$ Rijenbemesting $\mathrm{V}=$ Volveldse bemesting $\mathrm{K}=\mathrm{K} 2 \mathrm{O} \mathrm{BW}=$ Breedwerpig Rij=Rijenbemesting $\mathrm{N}=$ stikstofbemesting 


\section{Proefveldschema Marwijksoord 2016}

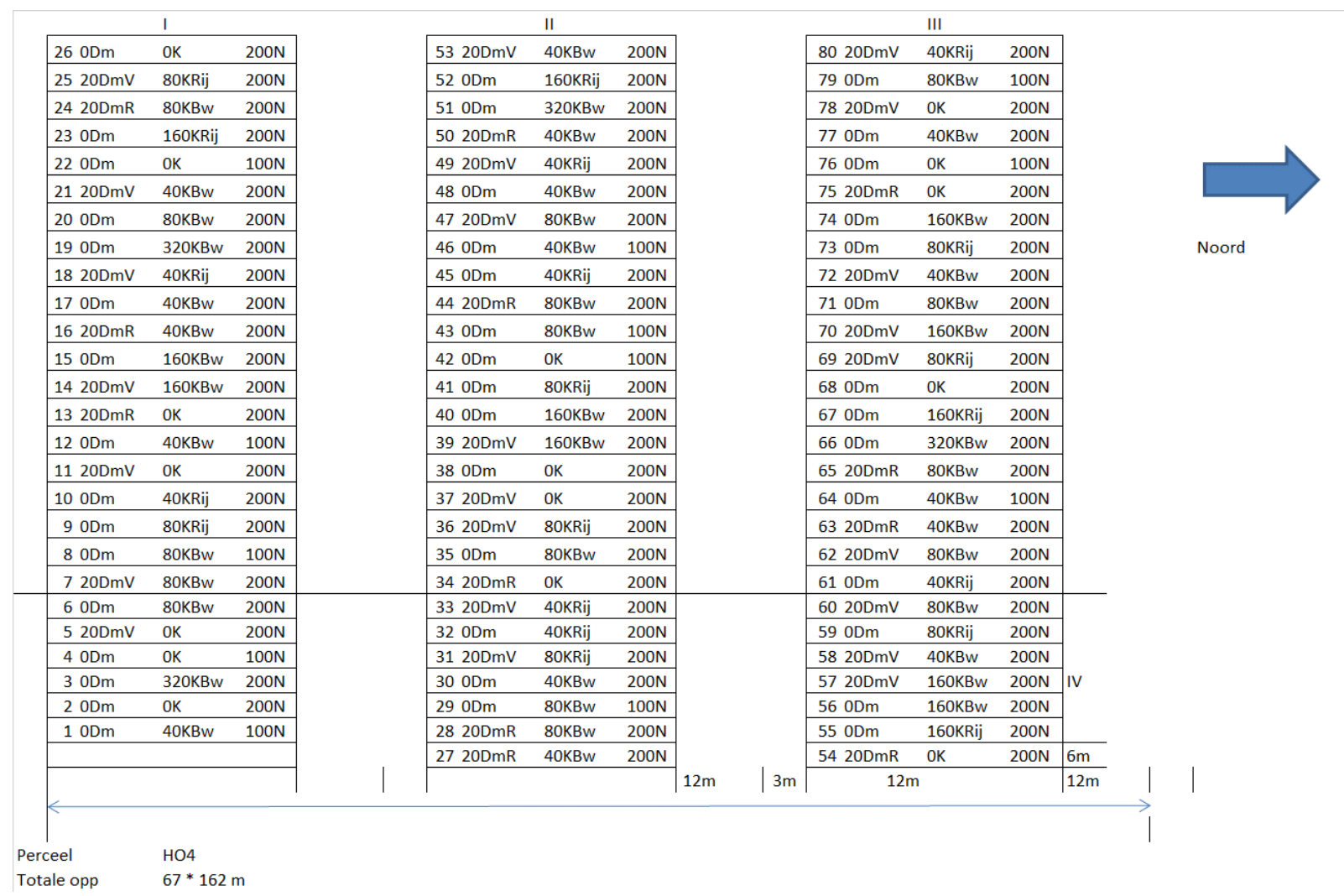

Proefveldschema Vredepeel 2017

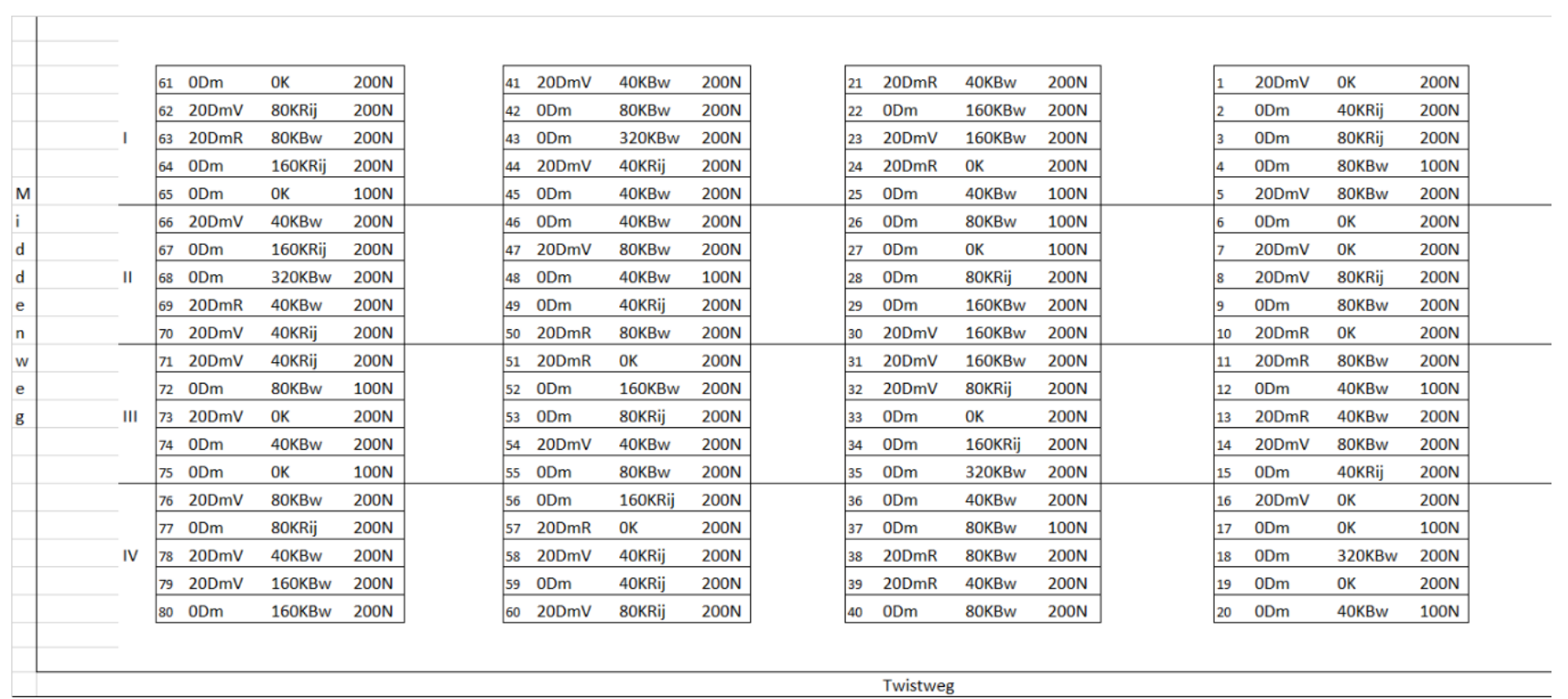

$\mathrm{Dm}=$ drijfmest $\mathrm{R}=$ Rijenbemesting $\mathrm{V}=$ Volveldse bemesting $\mathrm{K}=\mathrm{K} 2 \mathrm{O} \mathrm{Bw}=$ Breedwerpig Rij=Rijenbemesting $\mathrm{N}=$ stikstofbemesting 


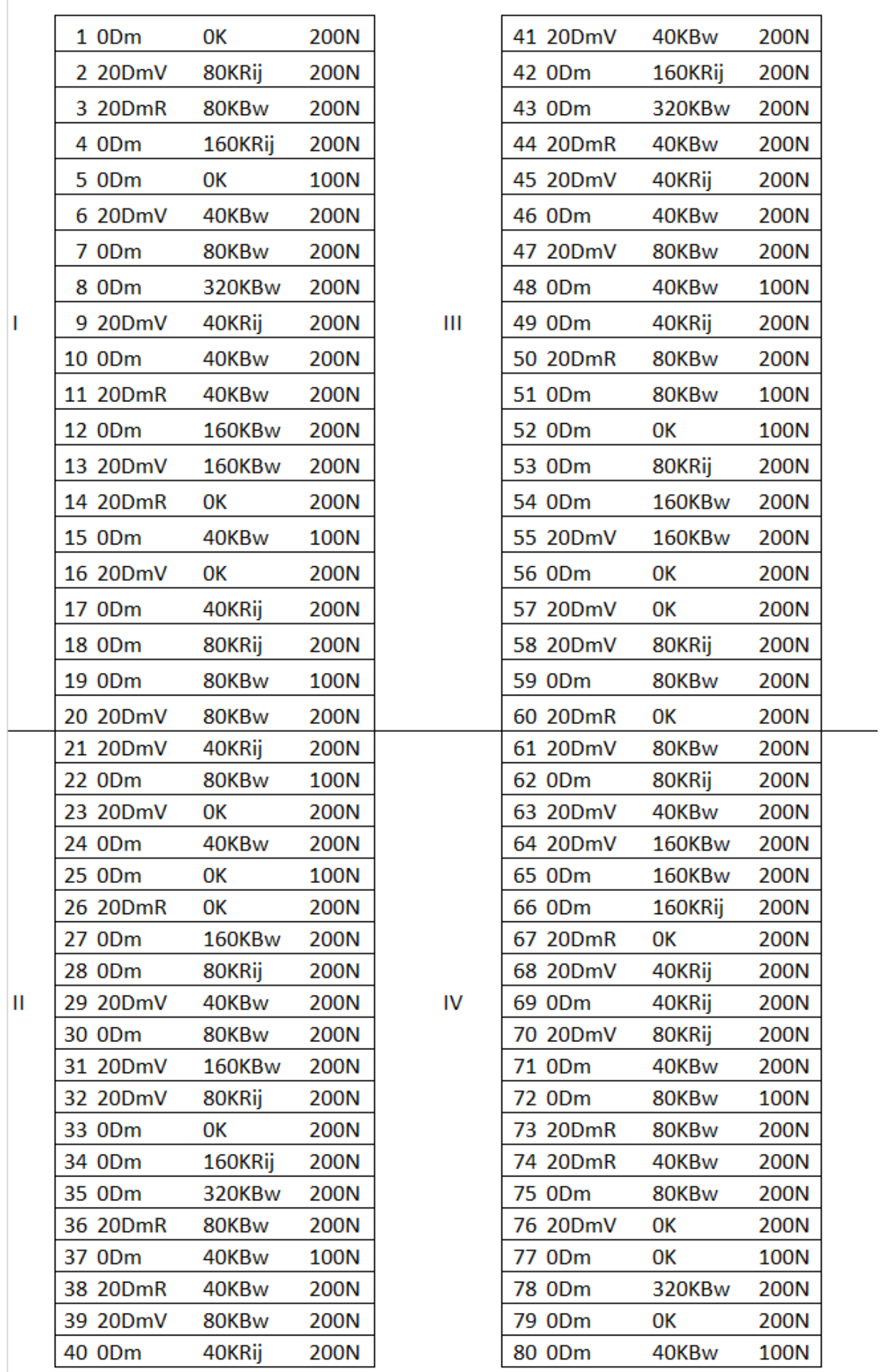

Dm = drijfmest $\mathrm{R}=$ Rijenbemesting $\mathrm{V}=$ Volveldse bemesting $\mathrm{K}=\mathrm{K} 2 \mathrm{O} \mathrm{Bw}=$ Breedwerpig Rij=Rijenbemesting $N=$ stikstofbemesting 
Locatie Marwijksoord algemene gegevens 2015 en 2016

Voorvrucht

: $\quad$ Minstens 3 jaar bouwland

Ras

: P8057

Rijenafstand

: $\quad 75 \mathrm{~cm}$

Zaai-/Plantmoment

: $\quad$ Eind april

Veldjesgrootte

: bruto : $6 \times 12 \mathrm{~m}$

zaaien : $6 \times 12 \mathrm{~m}$

Netto : $3 \times 10,5 \mathrm{~m}$

Aantal planten/veldje $\quad: \quad 100.000$

Locatie Vredepeel algemene gegevens 2015 en 2017

Voorvrucht

: $\quad$ Minstens 3 jaar bouwland

Ras

: Torres

Rijenafstand

: $\quad 75 \mathrm{~cm}$

Zaai-/Plantmoment

: Eind april

Veldjesgrootte

: bruto : $6 \times 12 \mathrm{~m}$

zaaien : $6 \times 14 \mathrm{~m}$

Netto : $3 \times 10,5 \mathrm{~m}$

Aantal planten/veldje $\quad: \quad 100.000$

Locatie Wageningen algemene gegevens 2015 en 2017

Voorvrucht

Ras

Rijenafstand

Zaai-/Plantmoment

Veldjesgrootte
: $\quad$ Minstens 3 jaar bouwland

: P8057

: $\quad 75 \mathrm{~cm}$

: $\quad$ Eind april

: bruto : $6 \times 14 \mathrm{~m}$

zaaien : $6 \times 14 \mathrm{~m}$

Netto : $3 \times 12 \mathrm{~m}$

100.000 


\section{Bijlage 2 Weersomstandigheden detailproeven (details)}

Van alle 3 proefjaren zijn per locatie de weergegevens (temperatuur en neerslag) weergegeven in steeds 2 figuren per locatie per jaar. Links wordt de gemiddelde temperatuur per etmaal gedurende het jaar uitgezet tegen de gemiddelde etmaaltemperatuur over 30 jaar, om een beeld te krijgen of er juist warmere dan wel koudere perioden zijn geweest dan gemiddeld, en de neerslag per dag $(\mathrm{mm})$. In de tweede figuur staat de cumulatieve neerslag en verdamping en het cumulatieve neerslagoverschot (neerslag minus verdamping). Deze laatste voor zowel het proefjaar als het 30jarig gemiddelde voor de locatie. Deze figuur geeft een beeld van eventueel opgetreden vochttekorten.

Marwijksoord 2015 en 2016

a

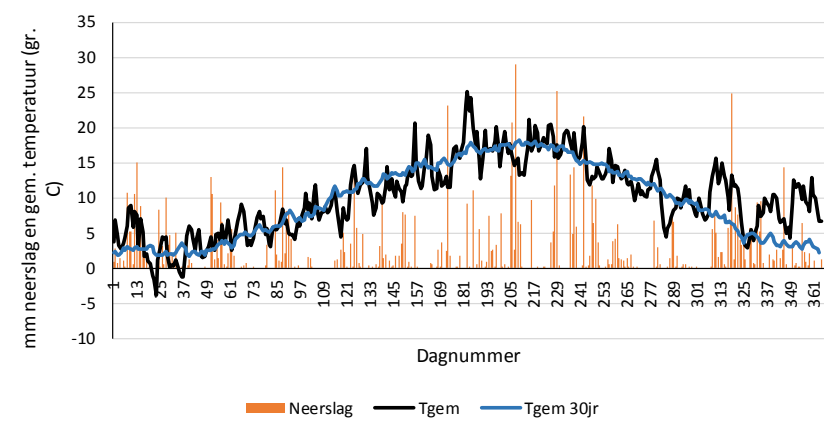

b

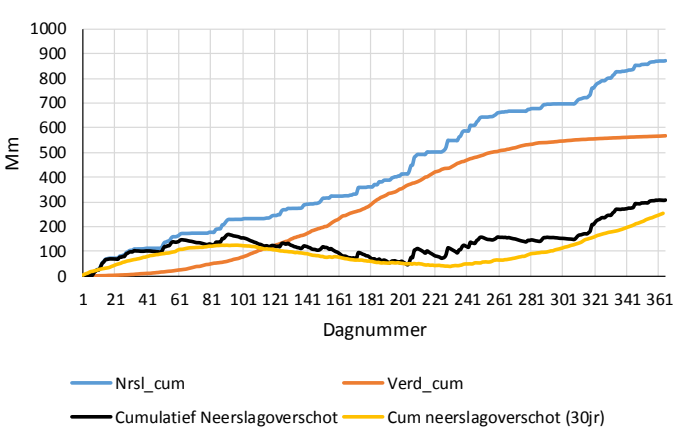

Figuur 19 a en b Temperatuur, neerslag en verdamping Marwijksoord 2015.

De temperatuur vertoonde in 2015 een redelijk normaal verloop (zwarte lijn) ten opzichte van het meerjarig gemiddelde (blauwe lijn). Rond de bloei (eind juli, dag 181) was sprake van een korte warmere periode dan normaal. Het neerslagoverschot (zwarte lijn in rechter figuur) was altijd positief en het jaar als totaal kende een iets hoger neerslagoverschot dan normaal (gele lijn). Wel waren gedurende het groeiseizoen 4 dagen met meer dan $20 \mathrm{~mm}$ neerslag in 24 uur. Totaal is bijna $700 \mathrm{~mm}$ gevallen gedurende het groeiseizoen; de periode voor oogst was relatief droog. De mais heeft geen zichtbare hinder ondervonden van de weersomstandigheden.

A

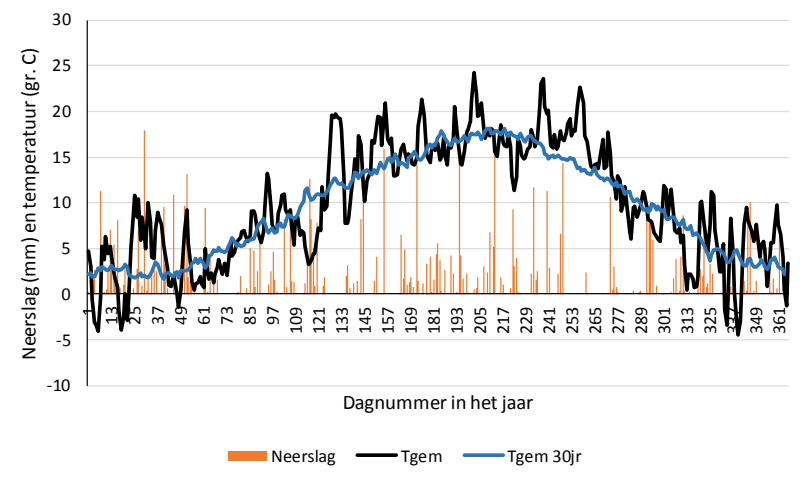

b

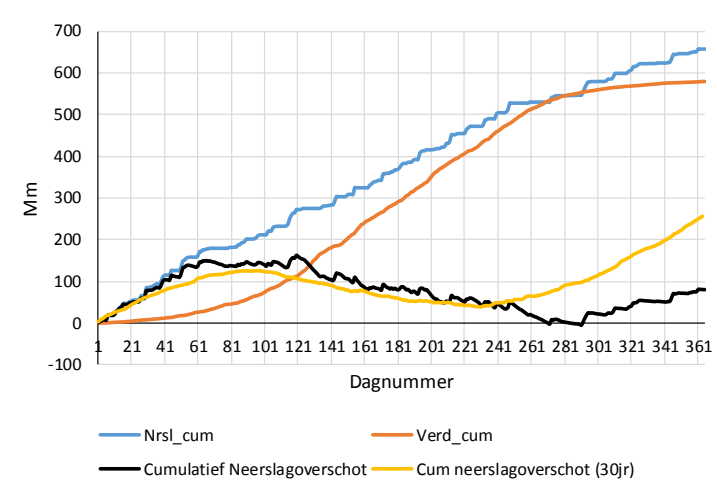

Figuur 20 a en b Temperatuur, neerslag en verdamping Marwijksoord 2016. 
Het voorjaar van 2016 was relatief koud eind april/begin mei (rondom dagnummer 125), maar kende daarna een warm vervolg. De temperatuur lag gedurende het gehele groeiseizoen boven het meerjarig gemiddelde, waarbij vooral het najaar bijzonder warm verliep. Gedurende de zomer is voldoende neerslag gevallen, maar vanaf augustus werd het droog. Dit is goed te zien in de rechter figuur; rond dag 260 is het neerslagoverschot lager dan normaal en vanaf dag 250 wijkt het neerslagoverschot duidelijk in negatieve zin af van het meerjarig gemiddelde en ook de totale neerslagsom is met ongeveer $550 \mathrm{~mm}$ gedurende het groeiseizoen laag te noemen. Het groeizame warme weer in heel 2016 met voldoende vocht tot de eerste kolfzetting heeft geleid tot een veel hogere opbrengst dan in het gemiddelde weerjaar 2015.

\section{Wageningen 2015, 2016 en 2017}

De neerslaggegevens voor de locatie Wageningen zijn op het proefveld gemeten. De temperatuur en gewasverdamping komen van het KNMI station Deelen.

a

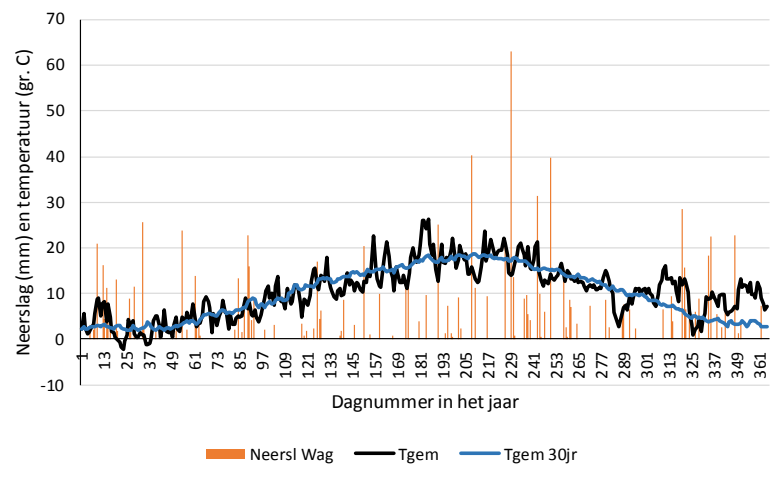

b

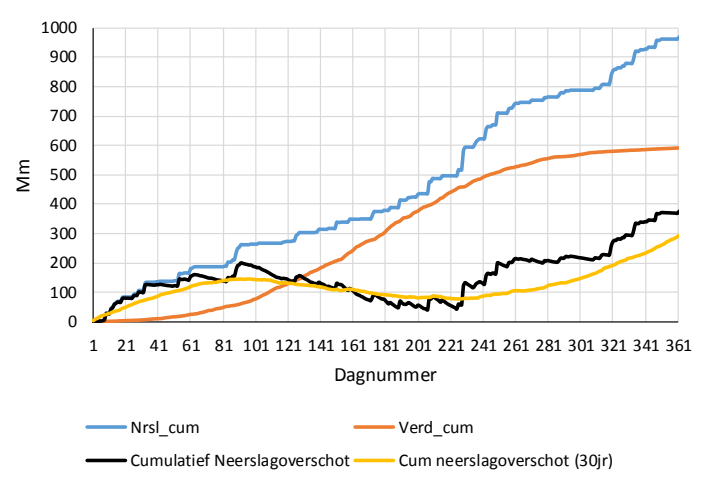

Figuur 21 a en b Temperatuur, neerslag en verdamping Wageningen 2015.

De temperatuur verliep in Wageningen in 2015 redelijk normaal. Er waren slechts een paar warmere dagen. Wel was 2015 nat. Totaal is tijdens het groeiseizoen tot oogst bijna $800 \mathrm{~mm}$ neerslag gevallen. Er was nooit sprake van een neerslagtekort; in augustus en september was het neerslagoverschot zelfs hoger an het meerjarig gemiddelde. Met name augustus kende enkele zeer natte dagen.

A

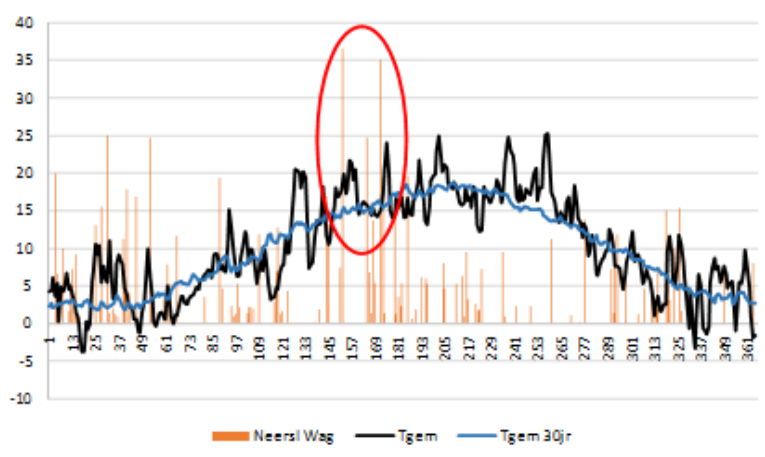

b

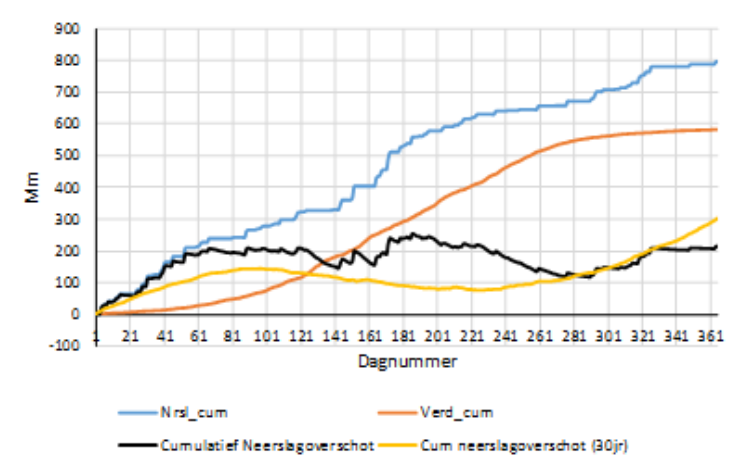

Figuur 22 a en b Temperatuur, neerslag en verdamping Wageningen 2016.

In figuur 22 a en b is de neerslag en verdamping voor Wageningen in 2016 weergegeven. In 2016 is de mais wel geoogst, maar heeft de groei ernstige hinder ondervonden van het vele water dat in mei en juni is gevallen. In figuur $22 \mathrm{a}$ is dit met de rode ellips aangegeven. Het water is te lang op het land blijven staan, waardoor zuurstofgebrek is opgetreden en de ontwikkeling van de maisplanten heeft stilgestaan en sommige plekken de planten volledig zijn afgestorven. Het beeld had teveel invloed op de aangelegde objecten (verschillen werden veroorzaakt door wateroverlast, niet door $\mathrm{K}$ bemesting), 
waardoor is afgezien van het meenemen van de resultaten uit 2016 in de analyse van de detailproeven. In de analyse van de miniproeven zijn de opbrengsten van de helft van het proefveld dat minder last van natschade had, wel meegenomen.

Het weer verliep in 2017 veel gunstiger voor een goede maisproductie. Er is in 20173.5 ton ds mais meer geoogst dan in 2015. Mogelijk is dit deels veroorzaakt door de gemiddeld hogere temperaturen. Het voorjaar kende net voor en rond het zaaien een koude periode, maar al snel na inzaai werd het warmer dan normaal. Met name in de eerste maanden van de ontwikkeling heeft de maïs goed kunnen profiteren van de hoge temperaturen. Ook gedurende de tweede helft van de zomer bleef de temperatuur op peil, maar week niet veel af van het meerjarig gemiddelde. Met name de eerste helft van het seizoen was droger dan normaal, maar dit heeft de groei niet heel negatief beïnvloed. Op 22 juni is de mais eenmalig beregend met een gift van $9 \mathrm{~mm}$.

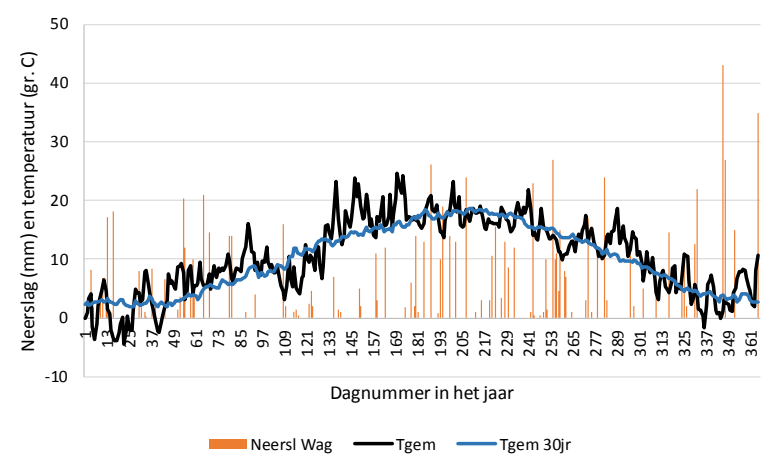

b

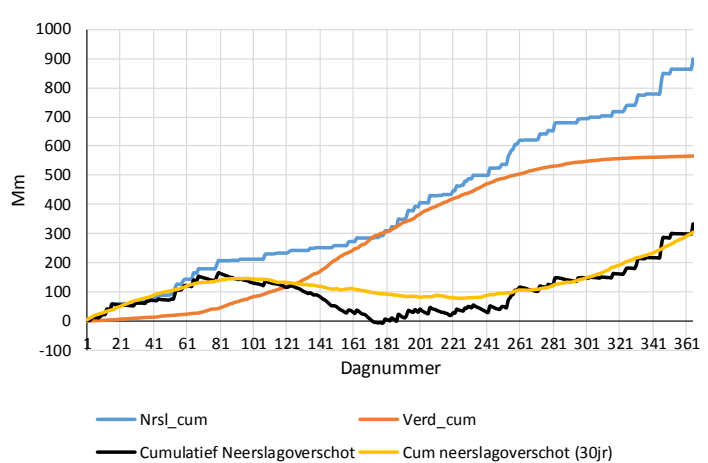

Figuur 23 a en b Temperatuur, neerslag en verdamping Wageningen 2017.

\section{Vredepeel 2015 en 2017}

De neerslaggegevens komen van het proefveld, de temperatuur en gewasverdamping van KNMI station Eindhoven. Het zuiden van het land geeft in het algemeen hogere temperaturen en meer verdamping, zeker in vergelijking met Marwijksoord, de andere locatie met zandgrond. De hogere opbrengsten op Vredepeel kunnen mogelijk mede toegeschreven worden aan de weersomstandigheden.

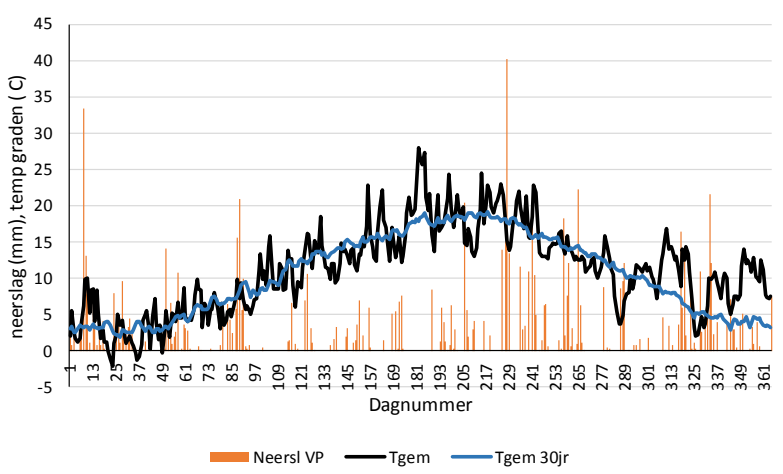

b

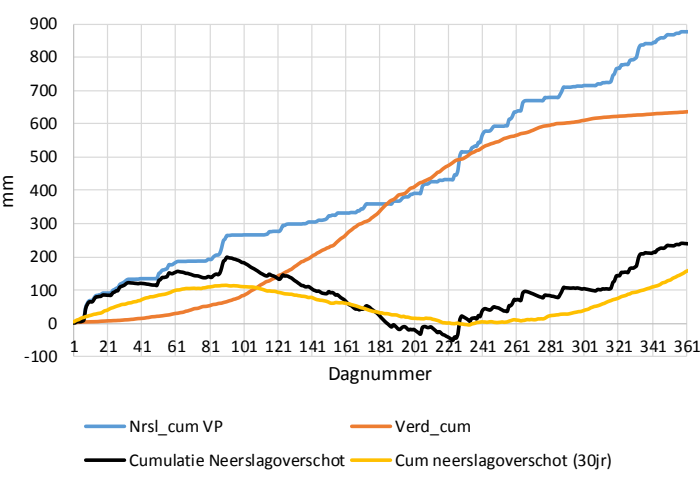

Figuur 24 a en b Temperatuur, neerslag en verdamping Vredepeel 2015.

Met name juni en juli in 2015 zijn iets warmer dan gemiddeld. Het voorjaar verliep iets natter, maar in juli en augustus (vanaf dag 180) is sprake van een neerslagtekort (zie figuur 24b, grijze lijn). In Vredepeel was in 2016 net als in Wageningen sprake van ernstige wateroverlast in juni, waardoor het proefveld als verloren moest worden beschouwd. De weerdata over 2016 zijn daarom niet gepresenteerd. 


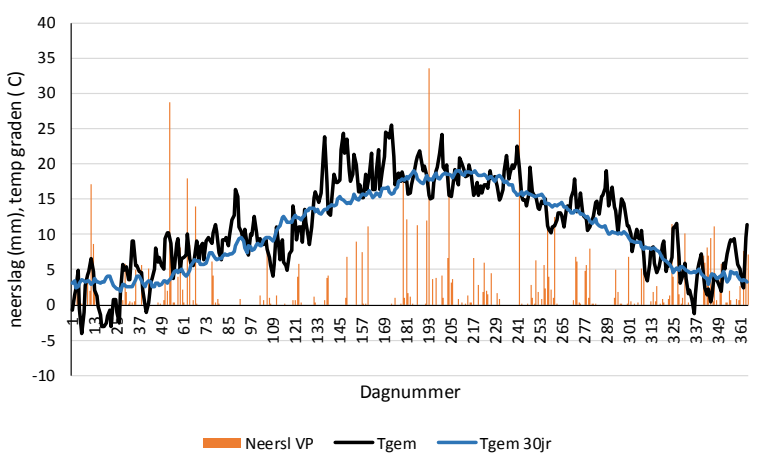

b

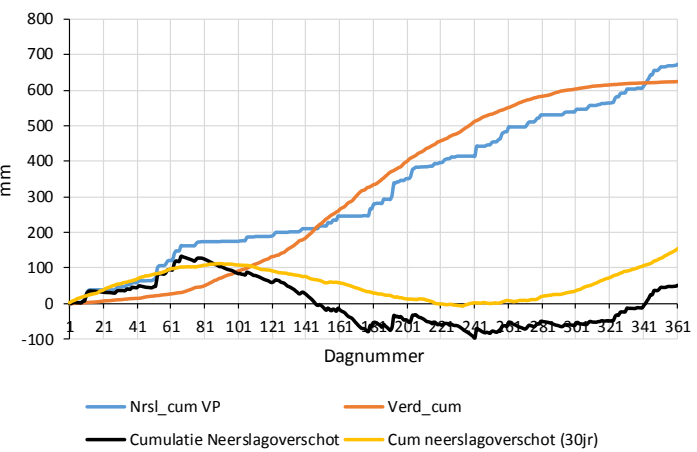

Figuur 10 a en b Temperatuur, neerslag en verdamping Vredepeel 2017.

De weerssituatie was in 2017 nog iets gunstiger voor een optimale maisproductie dan in 2015. De gegevens over 2017 zijn weergegeven in figuur 25 a en b.

Ook het zuiden kende een koude start in april gevolgd door een snelle opwarming. Met name mei en juni waren duidelijk warmer dan normaal, hetgeen voor een uitstekende beginontwikkeling van de mais zorgde. Bijna gedurende het gehele groeiseizoen was sprake van een neerslagtekort en het seizoen verliep droger dan normaal (vergelijking grijze en gele lijn in figuur 25b). De neerslag viel echter wel regelmatig verdeeld over de tijd, waardoor er waarschijnlijk weinig negatief effect is opgetreden. De maisopbrengst lag in 2017 op ruim 23 ton ds/ha. Dit was de hoogste opbrengst van alle locaties en jaren binnen dit onderzoek. 


\section{Bijlage 3 Resultaten drogestofopbrengst en $\mathrm{K}$-gehalte detailproeven}

Drogestofopbrengst
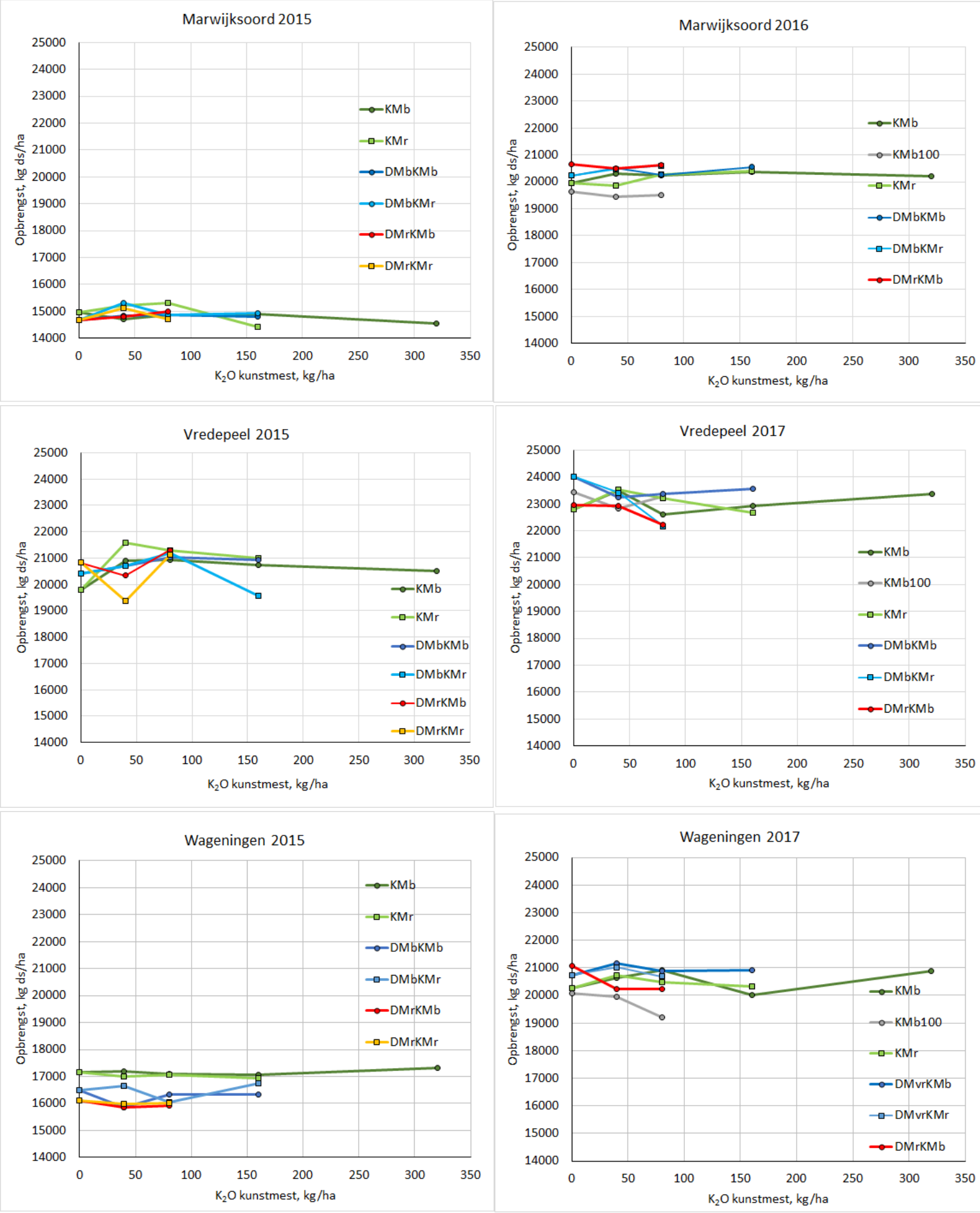

$\mathrm{KMb}=$ Kunstmest breedwerpig

$\mathrm{KMr}=$ Kunstmest in de rij

$\mathrm{DMb}=$ Drijfmest rundvee breedwerpig

$\mathrm{DMr}=$ Drijfmest rundvee in de rij

DMvr=Drijfmest varkens in de rij

Alle objecten bij N-bemesting 200 kg N/ha, m.u.v. KMb100 bij 100 kg N/ha 


\section{K-gehalte}
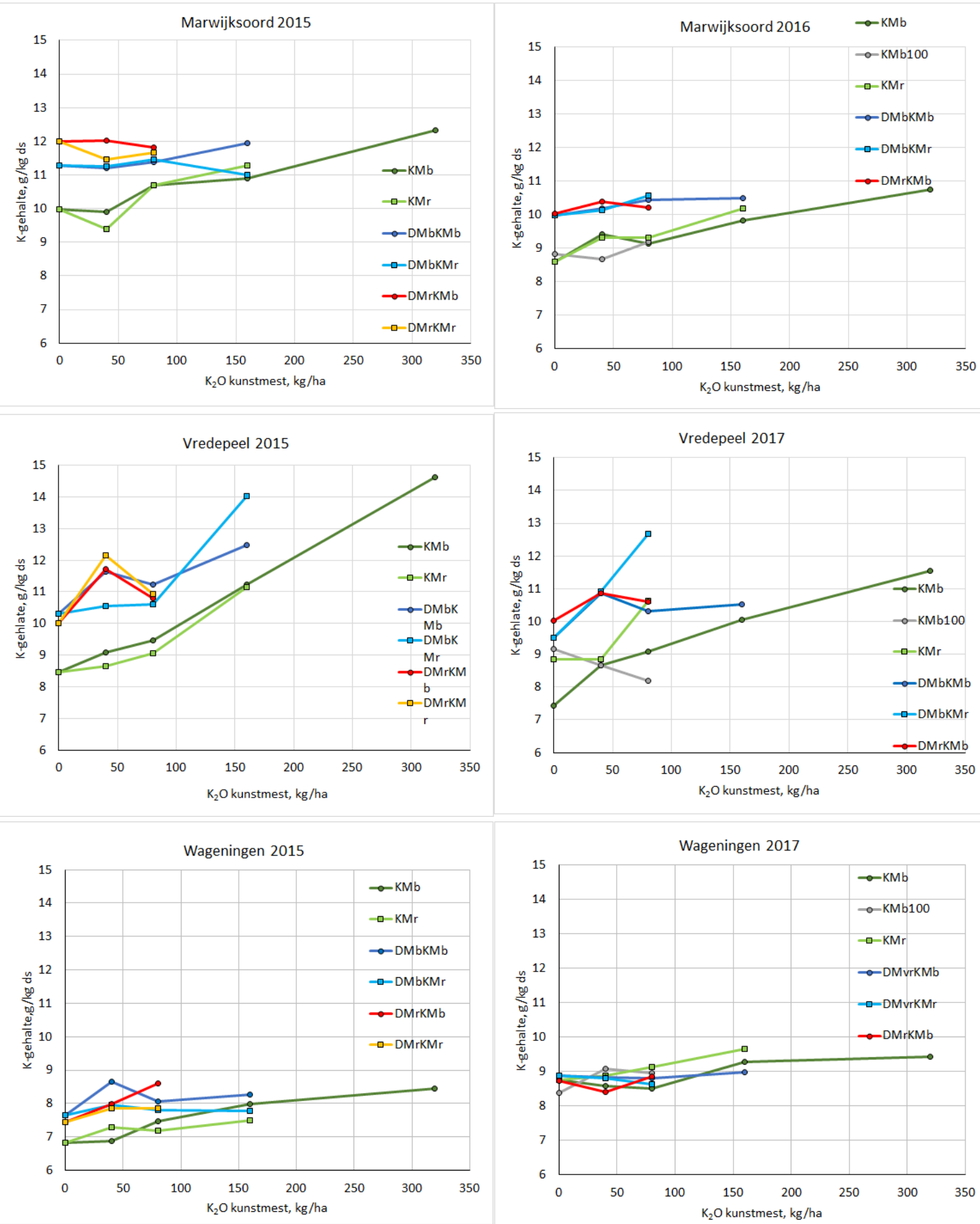

$\mathrm{KMb}=$ Kunstmest breedwerpig

$\mathrm{KMr}=$ Kunstmest in de rij

$\mathrm{DMb}=$ Drijfmest rundvee breedwerpig

$D M r=$ Drijfmest rundvee in de rij

DMvr=Drijfmest varkens in de rij

Alle objecten bij N-bemesting 200 kg N/ha, m.u.v. KMb100 bij 100 kg N/ha 


\section{Bijlage 4 Statistische analyse detailproeven}

\begin{tabular}{|c|c|c|c|}
\hline & Model onderdeel & Betekenis & Referentie (ten opzichte van) \\
\hline A & Locatie.oogstjaar & $\begin{array}{l}\text { Opbrengstniveau per locatie-jaar combinatie. Opbrengst } \\
\text { bij } \mathrm{K}_{2} \mathrm{O} \text {-bemesting } 0, \mathrm{~N} \text {-bemesting } 200 \text {, zonder drijfmest }\end{array}$ & 0 \\
\hline B & $\begin{array}{l}\text { Locatie.oogstjaar. } \\
\text { mest_type_KMOM }\end{array}$ & Effect van dierlijke mest volvelds & $0 \mathrm{~kg} \mathrm{~K}_{2} \mathrm{O}$ bemesting $(\mathrm{A})$ \\
\hline c & $\begin{array}{l}\text { Locatie.oogstjaar. } \\
\text { mest_type_KMOM. } \\
\text { rdm_plaatsing }\end{array}$ & Effect van dierlijke mest rijenbemesting & Volvelds dierlijke mest (B) \\
\hline $\mathrm{D}$ & $\begin{array}{l}\text { Locatie.oogstjaar. } \\
\text { Stikstofniveau }\end{array}$ & Effect van $\mathrm{N}$ niveau $100 \mathrm{~kg} \mathrm{~N}$ per ha & $200 \mathrm{~kg} \mathrm{~N}$ per ha (E) \\
\hline $\mathrm{E}$ & $\begin{array}{l}\text { Locatie.oogstjaar. } \\
\text { K2Ogift_KM }\end{array}$ & $\begin{array}{l}\text { Effect van } \mathrm{K}_{2} \mathrm{O} \text {-bemesting met kunstmest, volvelds } \\
\text { zonder drijfmest }\end{array}$ & $\begin{array}{l}0 \text { kg } \mathrm{K}_{2} \mathrm{O} \text { bemesting, per } \mathrm{kg} \mathrm{K}_{2} \mathrm{O} \\
\text { (A) }\end{array}$ \\
\hline $\mathrm{F}$ & $\begin{array}{l}\text { Locatie.oogstjaar. } \\
\text { K2Ogift_KM.km_plaatsing }\end{array}$ & $\begin{array}{l}\text { Effect van rijenbemesting } \mathrm{K}_{2} \mathrm{O} \text { kunstmest bij } 100 \mathrm{~kg} \mathrm{~N} \\
\text { per ha }\end{array}$ & $\begin{array}{l}\text { Bemesting met kunstmest } \mathrm{K}_{2} \mathrm{O} \\
\text { volvelds, per } \mathrm{kg} \mathrm{K} \mathrm{K}_{2} \mathrm{O}(\mathrm{E})\end{array}$ \\
\hline G & $\begin{array}{l}\text { Locatie.oogstjaar. } \\
\text { K2Ogift_KM.rdm_plaatsing }\end{array}$ & $\begin{array}{l}\text { Effect van } \mathrm{K}_{2} \mathrm{O} \text { kunstmest bij rijen- en volveldse } \\
\text { bemesting dierlijke mest }\end{array}$ & $\begin{array}{l}\text { Bemesting van alleen kunstmest } \\
\mathrm{K}_{2} \mathrm{O} \text {, per } \mathrm{kg} \mathrm{K}_{2} \mathrm{O}(\mathrm{E})\end{array}$ \\
\hline
\end{tabular}

Vereenvoudigd ziet het model er als volgt uit:

$\mathrm{Y}=\mathrm{A}+\mathrm{B}+\mathrm{C}+\mathrm{D}+(\mathrm{E}+\mathrm{F}+\mathrm{G}) * \mathrm{~kg} \mathrm{~K} \mathrm{~K}_{2} \mathrm{O} / \mathrm{ha}$

$\mathrm{Y}$ : kenmerk zoals drogestofopbrengst, $\mathrm{K}$-gehalte, K-opbrengst etc.

$A, B, C$ en D zijn discrete, additieve factoren. Dat wil zeggen dat ze opgeteld worden als ze significant zijn of de waarde 0 krijgen als ze niet significant zijn.

$\mathrm{E}$, F en $\mathrm{G}$ zijn continu, dat wil zeggen dat ze vermenigvuldigd worden met de bemestingsgift in $\mathrm{kg} \mathrm{K}_{2} \mathrm{O}$ per ha als ze significant zijn en de waarde 0 krijgen als ze niet significant zijn.

Tabel 31 Waarschijnlijkheid (probability) per kenmerk en per factor.

\begin{tabular}{|c|c|c|c|c|c|c|c|c|c|c|c|c|c|c|}
\hline & Kenmerk: & $\begin{array}{l}\text { Ds- } \\
\text { opb }\end{array}$ & $\begin{array}{l}\text { Vers } \\
\text { opb }\end{array}$ & Ds\% & $\begin{array}{l}\mathrm{K}- \\
\mathrm{opb}\end{array}$ & $\begin{array}{l}\text { K- } \\
\text { geh }\end{array}$ & VEM & DVE & OEB & SW & RE & NDF & $\begin{array}{l}\mathrm{CW} \\
\text { vert }\end{array}$ & $\begin{array}{l}\text { Zet- } \\
\text { meel }\end{array}$ \\
\hline & Model factor & & & & & & & & & & & & & \\
\hline A & Loc.jr = basisniveau & $* * *$ & $* * *$ & $* * *$ & $* * *$ & $* * *$ & $* * *$ & $* * *$ & $* * *$ & $* * *$ & $* * *$ & $* * *$ & $* * *$ & $* * *$ \\
\hline B & $\begin{array}{l}\text { Loc.jr.mest_type_KMO } \\
\mathrm{M}\end{array}$ & $* * *$ & $* * *$ & $* * *$ & $* * *$ & $* * *$ & nvt & nvt & nvt & nvt & nvt & nvt & nvt & nvt \\
\hline C & $\begin{array}{l}\text { Loc.jr.mest_type_KMO } \\
\text { M.rdm_plaatsing }\end{array}$ & 0.121 & 0.016 & ns & ns & 0.005 & nvt & nvt & nvt & nvt & nvt & nvt & nvt & nvt \\
\hline D & Loc.jr.Stikstofniveau & $* * *$ & 0.022 & ns & $\mathrm{ns}$ & ns & ns & ns & ns & ns & $* * *$ & ns & ns & ns \\
\hline$\underline{E}$ & Loc.jr.K2Ogift_KM & Ns & $* * *$ & $* * *$ & $* * *$ & $* * *$ & ns & 0.004 & $* * *$ & ns & 0.032 & ns & 0.058 & 0.002 \\
\hline $\mathrm{F}$ & $\begin{array}{l}\text { Loc.jr.K2Ogift_KM. } \\
\text { km_plaatsing }\end{array}$ & Ns & ns & $* * *$ & 0.011 & 0.011 & ns & ns & ns & ns & ns & ns & ns & ns \\
\hline G & $\begin{array}{l}\text { Loc.jr.K2Ogift_KM. } \\
\text { rdm_plaatsing }\end{array}$ & ns & ns & 0.002 & ns & ns & nvt & nvt & nvt & nvt & nvt & nvt & nvt & nvt \\
\hline
\end{tabular}

Loc.jr = Locatie.oogstjaar $* * *:<0.001$

$X=$ significant effect op 3 of meer locatie-jaar combinaties

$X=$ significant effect op 1 of 2 locatie-jaar combinaties

$\mathrm{Nvt}=$ niet van toepassing

NB: voederwaarde (VEM, DVE, OEB etc) is niet bepaald op drijfmestobjecten, daar nvt 


\section{Parameter schatting en standard error per kenmerk}

Tabel 32 Parameter schatting en standard error Drogestofopbrengst.

\begin{tabular}{|c|c|c|c|c|c|c|c|}
\hline & \multirow[t]{2}{*}{ Model factor } & \multicolumn{6}{|l|}{ Loc.jr } \\
\hline & & 15 & 16 & 15 & 17 & 15 & 17 \\
\hline & \multicolumn{7}{|l|}{ Parameter schatting } \\
\hline A & Loc.jr = basisniveau & 14867 & 20209 & 20839 & 23074 & 17102 & 20524 \\
\hline \multirow[t]{2}{*}{ D } & Loc.jr.Stikstofniveau & & -676 & & 115 & & -780 \\
\hline & Standard error & & & & & & \\
\hline C & $\begin{array}{l}\text { Loc.jr.mest_type_KMOM.rdm_plaatsing: } \\
\text { rijenbemesting }\end{array}$ & 221 & 267 & 221 & 267 & 221 & 267 \\
\hline $\mathrm{D}$ & Loc.jr.Stikstofniveau & & 255 & & 255 & & 255 \\
\hline
\end{tabular}

Vet: Significant

De drogestofopbrengsten verschillen tussen de locaties en jaren in niveau. In tabel 32 staan de geschatte drogestofopbrengsten zonder drijfmest of kalibemesting, dat zijn de basisniveaus. De laagste drogestofopbrengst is gevonden op Marwijksoord in 2015, en is 15 ton ds/ha. De hoogste drogestofopbrengst is gevonden op Vredepeel in 2017 en is 23 ton ds/ha.

Binnen de locaties zijn de verschillen tussen de jaren relatief groot: op alle proefvelden is de opbrengst in 2015 lager dan in het tweede jaar. Op de proefvelden van Vredepeel en Wageningen zijn de opbrengsten in 20153 ton ds/ha lager dan in 2017. In Marwijksoord is de opbrengt in 20155 ton ds/ha lager dan in 2016.

De effecten van de behandelingen op de drogestofopbrengst zijn vrijwel geen van allen significant. Alleen in Wageningen 2015 verlaagde toediening van drijfmest de opbrengst, zowel bij volveldse toediening als bij rijenbemesting, bij rijenbemesting wat meer dan bij volveldse bemesting. Op de locaties Marwijksoord en Wageningen zijn de drogestofopbrengsten in 2016 en 2017 lager bij de $\mathrm{N}$-bemesting van $100 \mathrm{~kg} \mathrm{~N} /$ ha ten opzichte van $200 \mathrm{~kg} \mathrm{~N} / \mathrm{ha}$. 
Tabel 33 Parameter schatting en standard error Vers opbrengst.

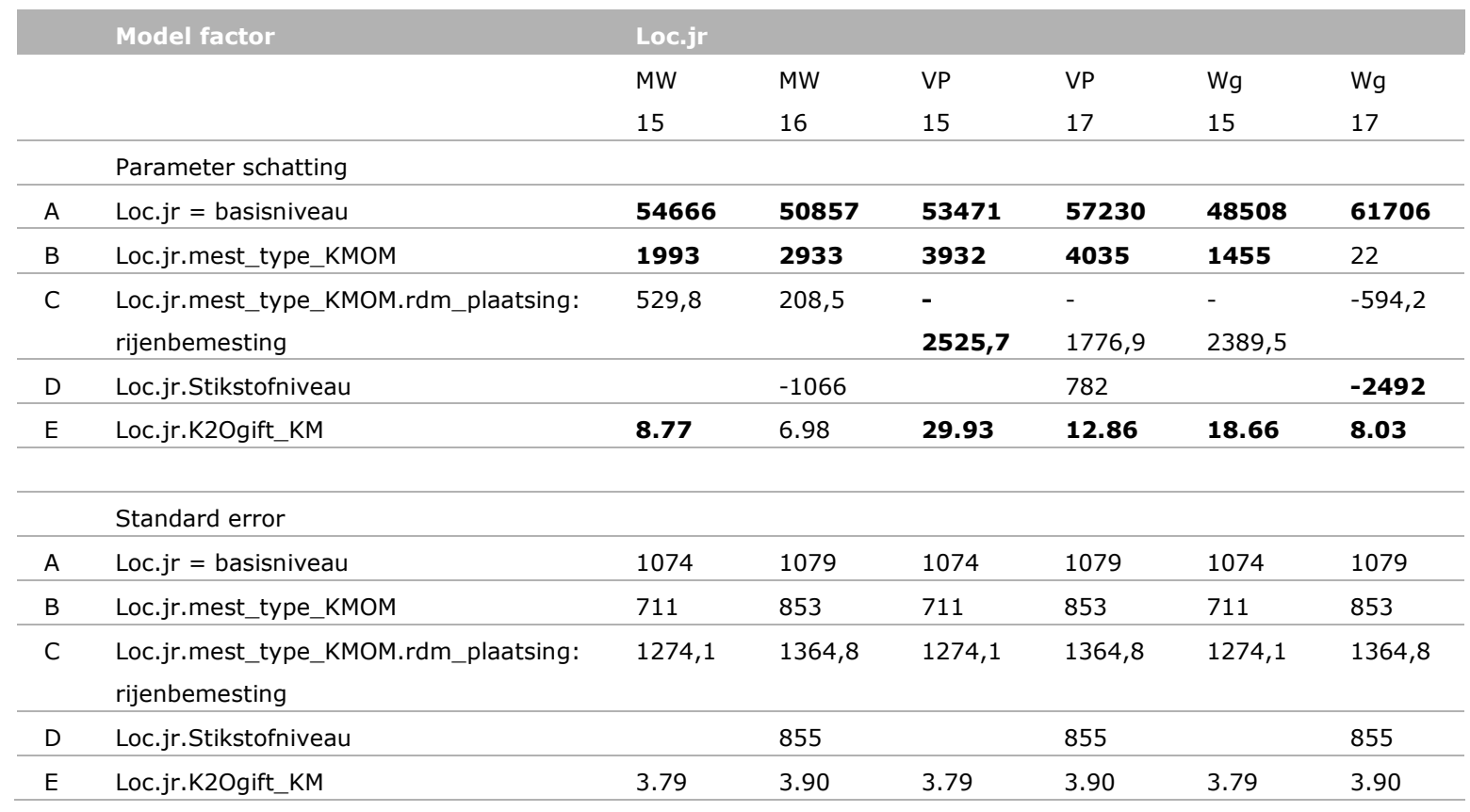

Vet: Significant

De vers opbrengsten verschillen tussen de locaties en jaren in niveau (Tabel 33). De laagst behaalde vers-opbrengst is 48.7 ton/ha op Wageningen 2015, en de hoogste is 61.8 ton/ha op Wageningen 2017.

Binnen die locatie is het verschil tussen de jaren het grootst: 13 ton $\mathrm{kg}$ vers/ha.

Bij toediening van dierlijke mest is op beide zandlocaties (Vredepeel en Marwijksoord) in beide jaren de vers-opbrengst hoger, op de kleilocaties (Wageningen) is het verschil niet significant. Dit geldt zowel voor volvelds als in de rij. Er is dan ook geen verschil tussen drijfmest in de rij en volvelds. Het effect van kalibemesting met kunstmest (volvelds) is op alle locaties en jaren significant, met uitzondering van Marwijksoord 2016.

Het verschil in effect van kunstmest is tussen jaren en locaties relatief groot. Op Vredepeel en Wageningen in 2015 wordt het grootste effect gevonden, 31.0 en $19.5 \mathrm{~kg} / \mathrm{ha}$ vers opbrengst per $\mathrm{kg}$ $\mathrm{K}_{2} \mathrm{O}$ bemesting, op Marwijksoord het kleinste, 8,4 en 7,0 kg vers opbrengst per $\mathrm{kg} \mathrm{K}_{2} \mathrm{O}$ bemesting . Het effect van een $\mathrm{N}$ niveau van $100 \mathrm{~kg} \mathrm{~N}$ per ha ten opzichte van $200 \mathrm{~kg} \mathrm{~N}$ per ha is alleen significant op Wageningen (2017).

Rijenbemesting kunstmest-K tov breedwerpig=referentie: effect van K-bemesting is meer positief alleen op Vredepeel 2017, andere situaties geen effect tov breedwerpig Plaatsing van drijfmest heeft geen effect op grootte van effect van $\mathrm{K}$ kunstmest. Ook geen verschil tussen rij of volvelds. Alleen bij rijenbemesting op Vredepeel 2017 maakt dat K kunstmest een kleiner effect heeft. 
Tabel 34 Parameter schatting drogestofpercentage.

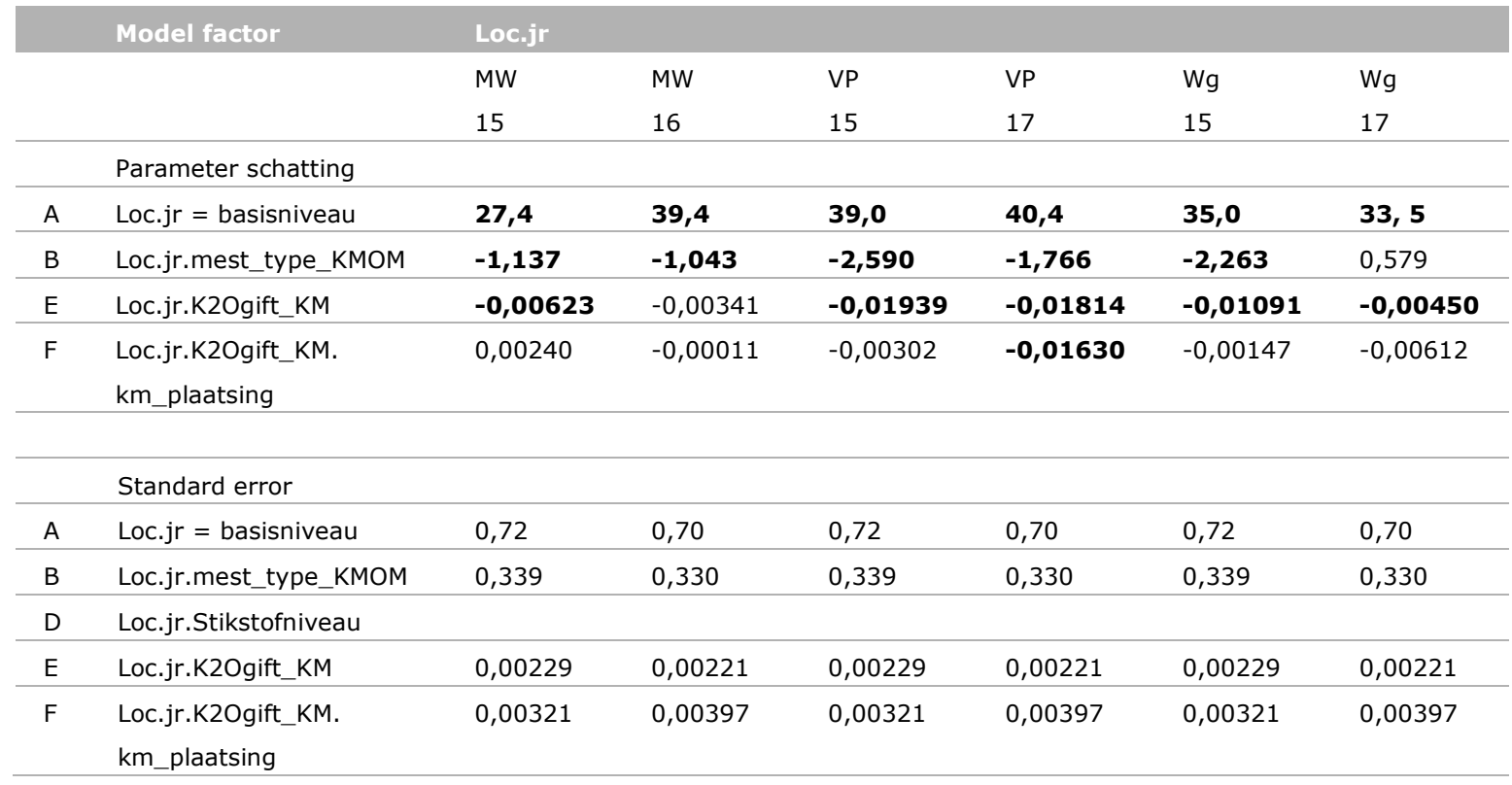

Vet: Significant

De drogestofpercentages (ds\%) verschillen tussen de locaties en jaren in niveau (Tabel 34, rij A). Het laagste ds\% is 27,4\% op Wageningen 2015, en de hoogste is 40,4\% op Vredepeel 2017.

Binnen de locatie Wageningen is het verschil tussen de jaren het grootst: ruim $12 \%$.

Bij toediening van dierlijke mest (rij B) is op beide zandlocaties (Vredepeel en Marwijksoord) in beide jaren het ds\% lager ten opzichte van geen driffmest, op de kleilocatie (Wageningen) is het verschil in 2015 wel en in 2017 niet significant. Dit geldt zowel voor volvelds als in de rij. Er is geen verschil in effect tussen drijfmest in de rij en volvelds.

Het effect van kalibemesting met kunstmest (volvelds, rij E) is op alle locaties en jaren significant, meer kali betekent een lager ds\%, met uitzondering van Marwijksoord 2016.

$\mathrm{Er}$ is een relatief groot verschil tussen jaren en locaties in effect van kali-bemesting met kunstmest. Op Vredepeel 2015 wordt het grootste effect gevonden, $-0.019 \%$ per $\mathrm{kg} \mathrm{K}_{2} \mathrm{O}$-bemesting, op Marwijksoord het kleinste, $-0.005 \%$ per $\mathrm{kg} \mathrm{K}_{2} \mathrm{O}$-bemesting.

Het effect van K-bemesting met kunstmest is bij drijfmest-rijenbemesting niet anders dan bij volveldse bemesting met drijfmest, met uitzondering van Vredepeel 2017, daar verlaagt de kalibemesting het $\mathrm{ds} \%$ sterker dan bij volveldse drijfmesttoediening. 
Tabel 35 Parameter schatting K-gehalte.

\begin{tabular}{|c|c|c|c|c|c|c|c|}
\hline & \multirow[t]{2}{*}{ Model factor } & \multicolumn{6}{|l|}{ Loc.jr } \\
\hline & & 15 & 16 & 15 & 17 & 15 & 17 \\
\hline & \multicolumn{7}{|l|}{ Parameter schatting } \\
\hline A & Loc.jr = basisniveau & 10,00 & 8,80 & 8,12 & 8,13 & 7,04 & 8,67 \\
\hline$E$ & Loc.jr.K2Ogift_KM & 0,0067 & 0,0057 & 0,0191 & 0,0093 & 0,0047 & 0,0025 \\
\hline $\mathrm{F}$ & $\begin{array}{l}\text { Loc.jr.K2Ogift_KM. } \\
\text { km_plaatsing }\end{array}$ & $-0,0026$ & 0,0028 & 0,0001 & 0,0083 & $-0,0033$ & 0,0026 \\
\hline A & Loc.jr = basisniveau & 0,23 & 0,22 & 0,23 & 0,22 & 0,23 & 0,22 \\
\hline $\mathrm{B}$ & Loc.jr.mest_type_KMOM & 0,37 & 0,38 & 0,37 & 0,38 & 0,37 & 0,38 \\
\hline $\mathrm{C}$ & $\begin{array}{l}\text { Loc.jr.mest_type_KMOM.rdm_ } \\
\text { plaatsing: rijenbemesting }\end{array}$ & 0,26 & 0,31 & 0,26 & 0,31 & 0,26 & 0,31 \\
\hline$E$ & Loc.jr.K2Ogift_KM & 0,0014 & 0,0014 & 0,0014 & 0,0014 & 0,0014 & 0,0014 \\
\hline $\mathrm{F}$ & $\begin{array}{l}\text { Loc.jr.K2Ogift_KM. } \\
\text { km_plaatsing }\end{array}$ & 0,0021 & 0,0025 & 0,0021 & 0,0025 & 0,0021 & 0,0025 \\
\hline
\end{tabular}

Vet: Significant

Loc.jr = Locatie. oogstjaar

Er zijn relatief grote verschillen in K-gehalten tussen locatie-jaar combinaties (rij A).

Het volvelds toedienen van dierlijke mest ( $r i j$ B) heeft een positief effect op het K-gehalte, met uitzondering van Wageningen in 2017. Toediening van drijfmest in de rij (rij C) heeft alleen op Marwijksoord in 2015 een positief effect op K-gehalte.

In alle situaties is er effect van volvelds kunstmest kali op het K-gehalte (rij E), de verschillen in effect zijn wel relatief groot.

Rijenbemesting met kunstmest kali (rij F) heeft geen ander (hoger) effect dan breedwerpig toediende kali kunstmest met uitzondering van Vredepeel 2017: daar heeft rijenbemesting een sterker effect per kg kalibemesting dan volvelds.

Tabel 21 Parameter schatting K-opbrengst.

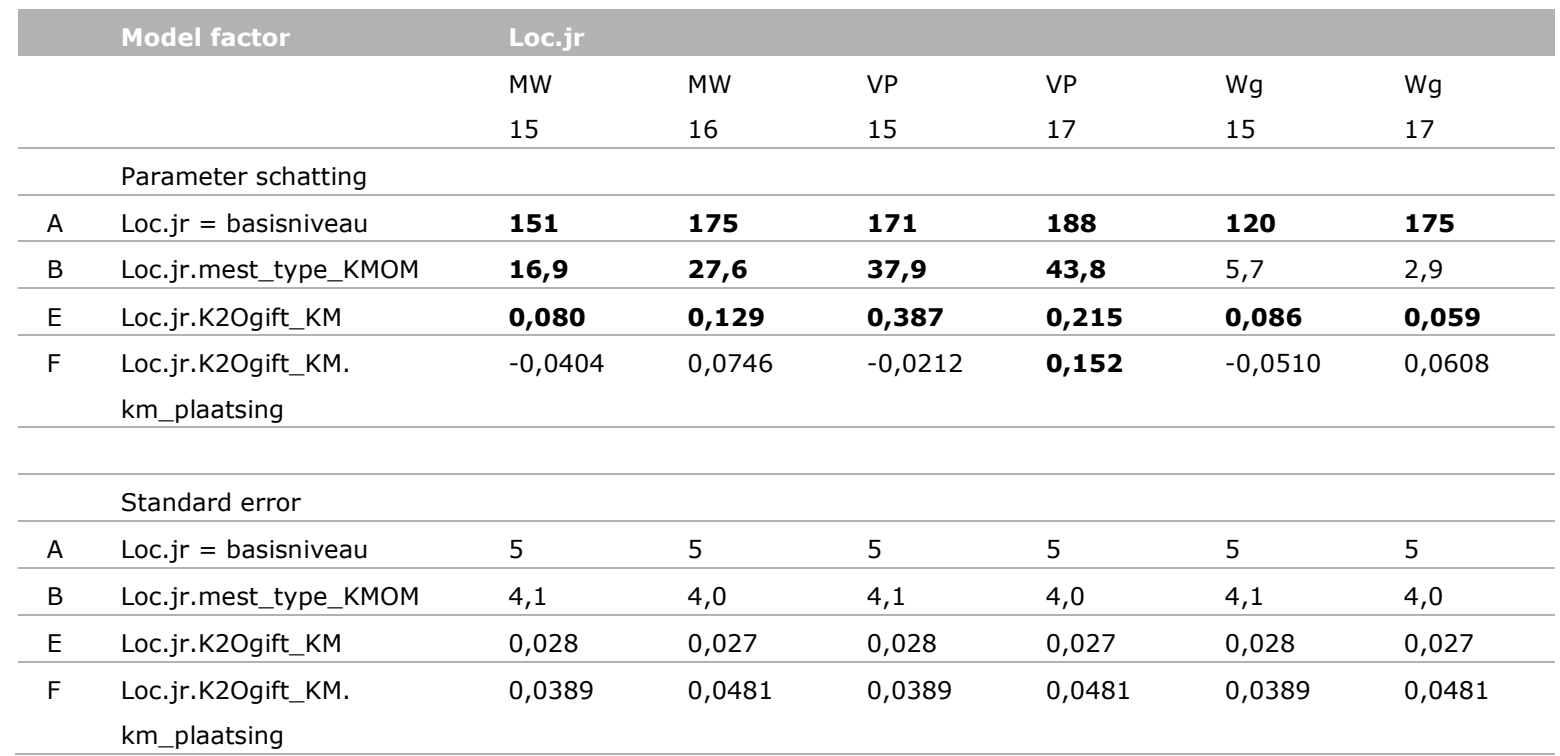

Vet: Significant 
De K-opbrengsten verschillen tussen de locaties en jaren in niveau (Tabel 36, rij A). De laagst behaalde $\mathrm{K}$-opbrengst is $119 \mathrm{~kg} \mathrm{~K} / \mathrm{ha}$ (= $143 \mathrm{~kg} \mathrm{~K}$ O/ha) op Wageningen 2015, en de hoogste is 180 $\mathrm{kg} \mathrm{K} / \mathrm{ha}$ ( $=2017 \mathrm{~kg} \mathrm{~K}$ O/ha) op Vredepeel 2017. Binnen de locaties zijn de verschillen tussen de jaren relatief groot: op alle proefvelden is de K-opbrengst in 2015 het laagst. Op de proefvelden van Marwijksoord is het verschil tussen jaren $30 \mathrm{~kg} \mathrm{~K} / \mathrm{ha}\left(=36 \mathrm{~kg} \mathrm{~K}{ }_{2} \mathrm{O}\right.$ ), van Vredepeel $13 \mathrm{~kg} \mathrm{~K} / \mathrm{ha}(=16$ $\mathrm{kg} \mathrm{K}_{2} \mathrm{O}$ ), en op Wageningen $58 \mathrm{~kg} \mathrm{~K} / \mathrm{ha}\left(=70 \mathrm{~kg} \mathrm{~K}{ }_{2} \mathrm{O}\right)$.

Bij toediening van dierlijke mest ( $r i j \mathrm{~B}$ ) is op beide zandlocaties (Vredepeel en Marwijksoord) in beide jaren de K-opbrengst hoger dan zonder dierlijke mest, op de kleilocaties (Wageningen) is het verschil niet significant. Dit geldt zowel voor volvelds als in de rij. Er is geen verschil tussen drijfmest in de rij en volvelds.

Het effect van K-bemesting met kunstmest (volvelds, rij E) is op alle locaties en jaren significant. $\mathrm{Er}$ is wel een relatief groot verschil tussen jaren en locaties. Op Vredepeel het grootste effect, 0,39 en $0,22 \mathrm{~kg} \mathrm{~K}$ opbrengst per $\mathrm{kg} \mathrm{K}_{2} \mathrm{O}$ bemesting, op Wageningen het kleinste, 0,09 en 0,06 kg $\mathrm{K}$ opbrengst per $\mathrm{kg} \mathrm{K} \mathrm{K}_{2} \mathrm{O}$ bemesting. Omgerekend naar een respons van 0.50 en $0.33 \mathrm{~kg} \mathrm{~K} / \mathrm{kg} \mathrm{K}$ op locatie Vredepeel en 0.11 en $0.07 \mathrm{~kg} \mathrm{~K} / \mathrm{kg} \mathrm{K}$ op locatie Wageningen.

Het effect van K-bemesting met kunstmest in de rij (rij F) was alleen op Vredepeel in 2017 significant hoger dan kunstmest volvelds.

Het effect van een $\mathrm{N}$ niveau van $100 \mathrm{~kg} \mathrm{~N}$ per ha ten opzichte van $200 \mathrm{~kg} \mathrm{~N}$ per ha was niet significant.

Plaatsing van drijfmest had geen effect op grootte van effect van K kunstmest. 
Tabel 37 Parameter schatting en standard error VEM.

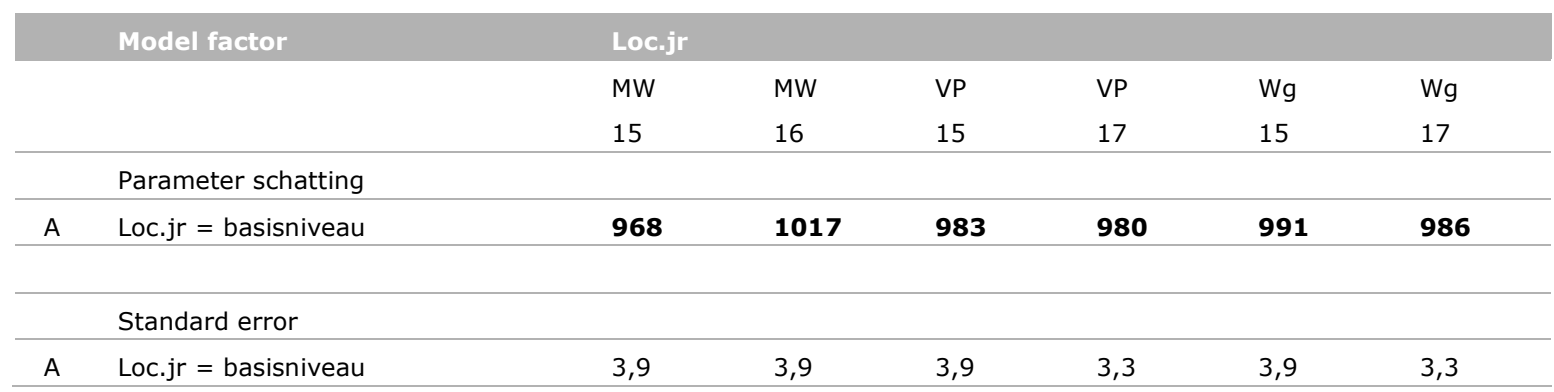

Vet: Significant

Loc.jr = Locatie.oogstjaar

In VEM is er alleen een verschil tussen locatie-jaar combinaties. De behandelingen met kunstmest hadden geen effect. Op de behandelingen met drijfmest is VEM niet bepaald.

Tabel 38 Parameter schatting DVE.

\begin{tabular}{|c|c|c|c|c|c|c|c|}
\hline & \multirow[t]{2}{*}{ Model factor } & \multicolumn{6}{|l|}{ Loc.jr } \\
\hline & & 15 & 16 & 15 & 17 & 15 & 17 \\
\hline & \multicolumn{7}{|l|}{ Parameter schatting } \\
\hline A & Loc.jr = basisniveau & 64,7 & 59,0 & 55,9 & 55,0 & 60,7 & 57,3 \\
\hline$E$ & Standard error & & & & & & \\
\hline A & Loc.jr = basisniveau & 0.62 & 0.62 & 0.62 & 0.56 & 0.62 & 0.56 \\
\hline$E$ & Loc.jr.K2Ogift_KM & 0.0032 & 0.0032 & 0.0032 & 0.0031 & 0.0032 & 0.0031 \\
\hline
\end{tabular}

Vet: Significant

In DVE is er alleen een verschil tussen locatie-jaar combinaties. De behandelingen met kunstmest hadden geen effect, met uitzondering van Wageningen 2015. Daar was er een positief effect van bemesting met $\mathrm{K}$ kunstmest.

Op de behandelingen met drijfmest is DVE niet bepaald. 
Tabel 39 Parameter schatting OEB.

\begin{tabular}{|c|c|c|c|c|c|c|c|}
\hline & \multirow[t]{2}{*}{ Model factor } & \multicolumn{6}{|l|}{ Loc.jr } \\
\hline & & 15 & 16 & 15 & 17 & 15 & 17 \\
\hline & \multicolumn{7}{|l|}{ Parameter schatting } \\
\hline A & Loc.jr = basisniveau & $-49,4$ & $-43,5$ & $-37,4$ & $-39,4$ & $-46,5$ & $-39,7$ \\
\hline$E$ & Standard error & & & & & & \\
\hline A & Loc.jr = basisniveau & 0,8 & 0,8 & 0,8 & 0,7 & 0,8 & 0,7 \\
\hline$E$ & Loc.jr.K2Ogift_KM & 0,0052 & 0,0052 & 0,0052 & 0,0048 & 0,0052 & 0,0048 \\
\hline
\end{tabular}

Vet: Significant

In OEB is er een verschil tussen locatie-jaar combinaties.

De behandelingen met kunstmest hadden een negatief effect op OEB op Marwijksoord 2016, Vredepeel 2015 en Wageningen 2015.

Op de behandelingen met drijfmest is OEB niet bepaald. 
Tabel 40 Parameter schatting Structuur warde.

\begin{tabular}{|c|c|c|c|c|c|c|c|}
\hline & \multirow[t]{2}{*}{ Model factor } & \multicolumn{6}{|c|}{ Loc.jr } \\
\hline & & 15 & 16 & 15 & 17 & 15 & 17 \\
\hline & \multicolumn{7}{|l|}{ Parameter schatting } \\
\hline A & Loc.jr = basisniveau & 2,08 & 1,61 & 1,71 & 1,59 & 1,77 & 1,54 \\
\hline$A$ & Loc.jr = basisniveau & 0,03 & 0,03 & 0,03 & 0,02 & 0,04 & 0,02 \\
\hline
\end{tabular}

Vet: Significant

In structuur waarde is er alleen een verschil tussen locatie-jaar combinaties. De behandelingen met kunstmest hadden geen effect. Op de behandelingen met drijfmest is structuur waarde niet bepaald.

Tabel 41 Parameter schatting ruw eiwit.

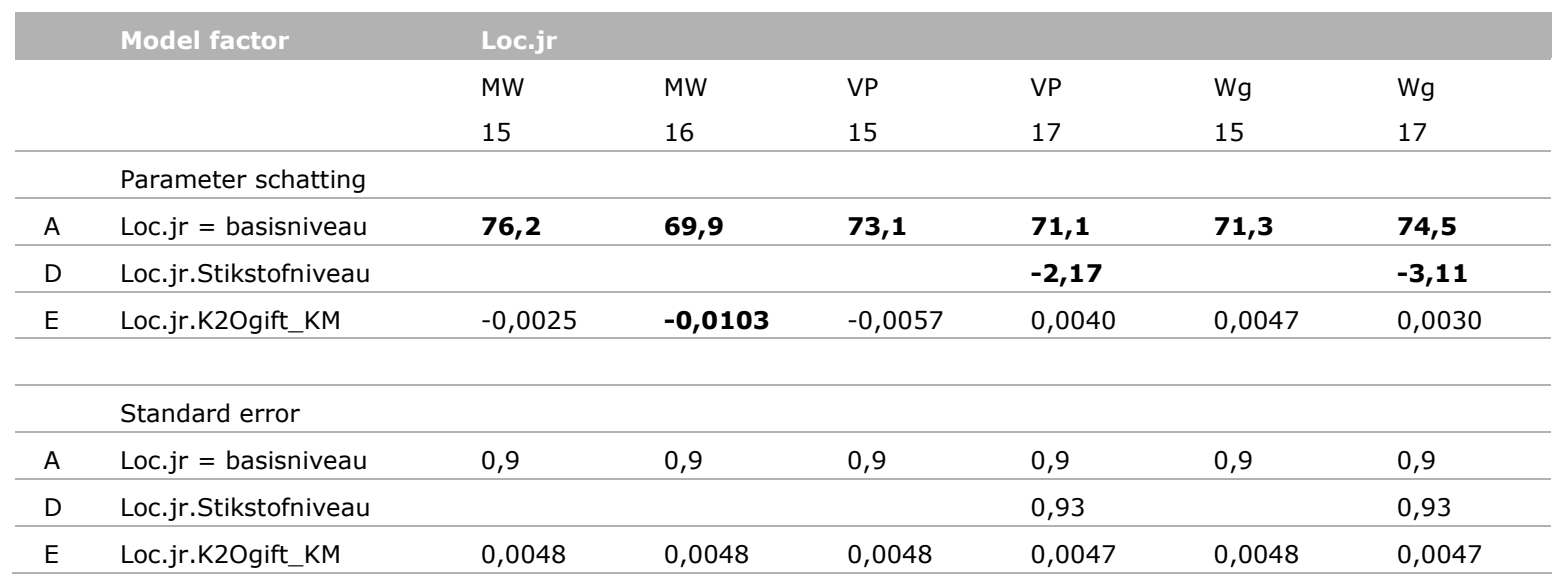

Vet: Significant

In ruw eiwit is er een verschil tussen locatie-jaar combinaties (rij A).

Het stikstofniveau (rij D) had op Vredepeel en Wageningen in 2017 een effect: minder stikstof betekende een lager re-gehalte.

De behandelingen met kunstmest kali had geen effect op ruw eiwit gehalte met uitzondering van Marwijksoord 2016. Daar had een bemesting met kunstmestkali een negatief effect.

Op de behandelingen met drijfmest is ruw eiwit niet bepaald. 
Tabel 42 Parameter schatting NDF.

\begin{tabular}{|c|c|c|c|c|c|c|c|}
\hline & \multirow[t]{2}{*}{ Model factor } & \multicolumn{6}{|l|}{ Loc.jr } \\
\hline & & 15 & 16 & 15 & 17 & 15 & 17 \\
\hline & \multicolumn{7}{|l|}{ Parameter schatting } \\
\hline A & Loc.jr = basisniveau & 442,2 & 365,0 & 378,4 & 359,7 & 391,1 & 350,9 \\
\hline A & Loc.jr = basisniveau & 4,0 & 4,0 & 4,0 & 3,5 & 4,0 & 3,5 \\
\hline
\end{tabular}

Vet: Significant

In NDF is er alleen een verschil tussen locatie-jaar combinaties. De behandelingen met kunstmest hadden geen effect. Op de behandelingen met drijfmest is NDF niet bepaald.

Tabel 43 Parameter schatting Celwand verteerbaarheid.

\begin{tabular}{|c|c|c|c|c|c|c|c|}
\hline & \multirow[t]{2}{*}{ Model factor } & \multicolumn{6}{|l|}{ Loc.jr } \\
\hline & & 15 & 16 & 15 & 17 & 15 & 17 \\
\hline & \multicolumn{7}{|l|}{ Parameter schatting } \\
\hline A & Loc.jr = basisniveau & 56,0 & 57,1 & 53,2 & 50,9 & 55,6 & 50,9 \\
\hline E & Standard error & & & & & & \\
\hline$A$ & Loc.jr = basisniveau & 0,6 & 0,6 & 0,6 & 0,5 & 0,6 & 0,5 \\
\hline$E$ & Loc.jr.K2Ogift_KM & 0,0030 & 0,0030 & 0,0030 & 0,0028 & 0,0030 & 0,0028 \\
\hline
\end{tabular}

Vet: Significant

In celwand verteerbaarheid is er alleen een verschil tussen locatie-jaar combinaties. De behandelingen met kunstmest hadden geen effect, met uitzondering van Vredepeel 2017. Daar was er een negatief effect van bemesting met $\mathrm{K}$ kunstmest.

Op de behandelingen met drijfmest is celwand verteerbaarheid niet bepaald. 
Tabel 44 Parameter schatting Zetmeel.

\begin{tabular}{|c|c|c|c|c|c|c|c|}
\hline & \multirow[t]{2}{*}{ Model factor } & \multicolumn{6}{|l|}{ Loc.jr } \\
\hline & & 15 & 16 & 15 & 17 & 15 & 17 \\
\hline & \multicolumn{7}{|l|}{ Parameter schatting } \\
\hline$A$ & Loc.jr = basisniveau & 302,5 & 406,3 & 412,3 & 405,6 & 357,7 & 395,3 \\
\hline$E$ & \multicolumn{7}{|l|}{ Standard error } \\
\hline A & Loc.jr = basisniveau & 8,0 & 8,0 & 8,0 & 6,8 & 8,0 & 6,8 \\
\hline$E$ & Loc.jr.K2Ogift_KM & 0,04865 & 0,04865 & 0,04865 & 0,04458 & 0,04865 & 0,04458 \\
\hline
\end{tabular}

Vet: Significant

In zetmeel gehalte is er een verschil tussen locatie-jaar combinaties (rij A). Tussen de locaties en jaren zijn er grote verschillen. In 2015 varieert het zetmeel van 303 (Marwijksoord), 358 (Wageningen) en 412 (Vredepeel).

Binnen de locaties is de variatie tussen jaren eveneens groot, voor op Marwijksoord: 303 in 2015, 406 in 2016. In Wageningen is het verschil kleiner: 358 in 2015 en 395 in 2017. Op Vredepeel is het verschil gering: 412 in 2015 en 406 in 2017.

De bemesting met kunstmest kali (rij E) hadden een negatief effect op zetmeel op Marwijksoord, Vredepeel en Wageningen, alle drie in 2015. De grootte van het effect in 2015 is op de drie locaties redelijk vergelijkbaar, ongeveer $-0,12$ per $\mathrm{kg} \mathrm{K}_{2} \mathrm{O}$. Dus als er $300 \mathrm{~kg} \mathrm{~K} 2 \mathrm{O}$ gegeven wordt, is het zetmeel gemiddeld 36 lager dan geen $\mathrm{K}_{2} \mathrm{O}$.

Op de behandelingen met drijfmest is zetmeel gehalte niet bepaald. 


\section{Bijlage 5 Effectiviteit van $\mathrm{K}$ uit drijfmest ten opzichte van $\mathrm{K}$ uit kunstmest}

\section{Vraag: is $\mathrm{K}$ uit drijfmest even effectief als uit kunstmest?}

Antwoord op vraag is te geven door te berekenen hoe groot het effect van $\mathrm{K}$ uit drijfmest is ten opzichte van kunstmest (eerder is gekeken of drijfmest een effect heeft maar is het effect niet omgerekend naar $\mathrm{kg} \mathrm{K}$ ).

Om dit te bepalen zijn de regels $X$ en $Y$ aan de onderstaande tabellen toegevoegd. $X$ berekent het effect van $\mathrm{K}$, onafhankelijk of het van drijfmest of kunstmest komt en $\mathrm{Y}$ is het extra effect van de drijfmest. Als $Y$ niet significant is, is de $K$ uit drijfmest net zo effectief als de $K$ uit kunstmest.

Er blijkt vrijwel geen verschil te zijn in respons op $\mathrm{K}$ uit dierlijke mest of uit kunstmest van $\mathrm{K}$ opbrengst en K-gehalte. Alleen op Vredepeel 2017 is de K uit drijfmest significant effectiever dan de K uit kunstmest.

Tabel 45 Parameter schatting K-opbrengst: respons kunstmest versus dierlijke mest.

\begin{tabular}{|c|c|c|c|c|c|c|c|}
\hline & \multirow[t]{3}{*}{ Model factor } & \multicolumn{6}{|l|}{ Loc.jr } \\
\hline & & MW & MW & VP & VP & $\mathrm{Wg}$ & $\mathrm{Wg}$ \\
\hline & & 15 & 16 & 15 & 17 & 15 & 17 \\
\hline & \multicolumn{7}{|l|}{ Parameter schatting } \\
\hline A & Loc.jr = basisniveau & 152 & 177 & 171 & 194 & 118 & 176 \\
\hline$x$ & Loc.jr.K2Ogift & 0,08 & 0,14 & 0,39 & 0,23 & 0,09 & 0,07 \\
\hline \multirow[t]{2}{*}{ Y } & Loc.jr.K2Ogift.mest_type_KMOM & 0,0298 & 0,0519 & $-0,0076$ & 0,0911 & $-0,0249$ & 0,0330 \\
\hline & Standard error & & & & & & \\
\hline A & Loc.jr = basisniveau & 5 & 5 & 5 & 5 & 5 & 5 \\
\hline$x$ & Loc.jr.K2Ogift & 0,03 & 0,03 & 0,03 & 0,03 & 0,03 & 0,03 \\
\hline $\mathrm{Y}$ & Loc.jr.K2Ogift.mest_type_KMOM & 0,026 & 0,027 & 0,027 & 0,028 & 0,026 & 0,028 \\
\hline
\end{tabular}

Vet: Significant

Tabel 46 Parameter schatting K-gehalte: respons kunstmest versus dierlijke mest.

\begin{tabular}{llllllll} 
& Model factor & Loc.jr & & & & \\
& & MW & MW & VP & VP & Wg & Wg \\
& & 15 & 16 & 15 & 17 & 15 & 17 \\
\hline & Parameter schatting & & & & & & \\
\hline A & Loc.jr = basisniveau & $\mathbf{1 0 , 1 5}$ & $\mathbf{8 , 8 9}$ & $\mathbf{8 , 2 0}$ & $\mathbf{8 , 3 8}$ & $\mathbf{7 , 0 5}$ & $\mathbf{8 , 6 7}$ \\
\hline X & Loc.jr.K2Ogift & $\mathbf{0 , 0 0 6 2}$ & $\mathbf{0 , 0 0 6 0}$ & $\mathbf{0 , 0 1 9 1}$ & $\mathbf{0 , 0 0 9 9}$ & $\mathbf{0 , 0 0 4 2}$ & $\mathbf{0 , 0 0 3 1}$ \\
\hline Y & Loc.jr.K2Ogift.mest_type_KMOM & 0,0014 & 0,0018 & 0,0003 & $\mathbf{0 , 0 0 4 1}$ & 0,0008 & $-0,0025$ \\
\hline & & & & & & & \\
\hline & Standard error & & & & & & 0,23 \\
\hline A & Loc.jr= basisniveau & 0,26 & 0,23 & 0,25 & 0,23 & 0,26 & 0,0015 \\
\hline X & Loc.jr.K2Ogift & 0,0016 & 0,0015 & 0,0016 & 0,0015 & 0,0016 & 0,0014 \\
\hline Y & Loc.jr.K2Ogift.mest_type_KMOM & 0,0013 & 0,0014 & 0,0013 & 0,0014 & 0,0013 & 0 \\
\hline
\end{tabular}

Vet: Significant

Loc.jr $=$ Locatie. oogstjaar 

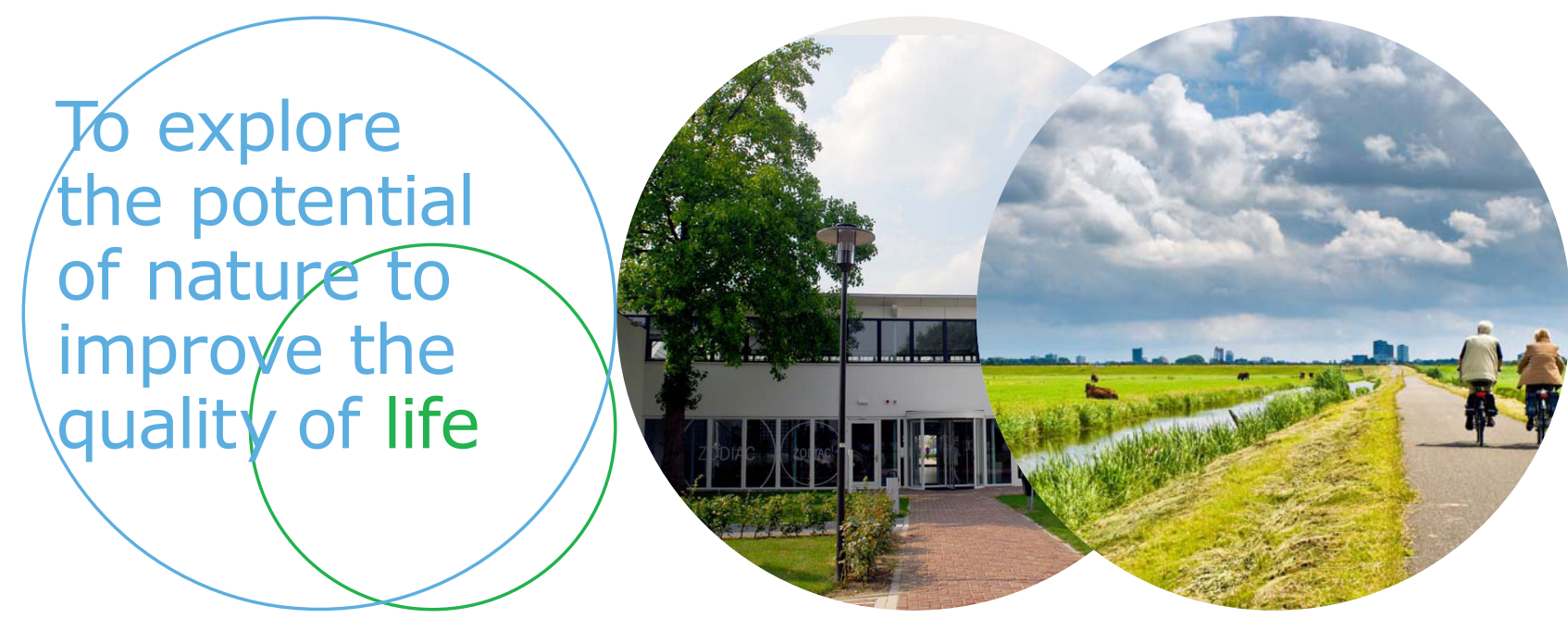

Wageningen Livestock Research Postbus 338

Wageningen Livestock Research ontwikkelt kennis voor een zorgvuldige en $6700 \mathrm{AH}$ Wageningen

T 0317483953

E info.livestockresearch@wur.nl www.wur.nl/ livestock-research renderende veehouderij, vertaalt deze naar praktijkgerichte oplossingen en innovaties, en zorgt voor doorstroming van deze kennis. Onze wetenschappelijke kennis op het gebied van veehouderijsystemen en van voeding, genetica, welzijn en milieu-impact van landbouwhuisdieren integreren we, samen met onze klanten, tot veehouderijconcepten voor de $21 \mathrm{e}$ eeuw.

De missie van Wageningen University \& Research is 'To explore the potential of nature to improve the quality of life'. Binnen Wageningen University \& Research bundelen 9 gespecialiseerde onderzoeksinstituten van Stichting Wageningen Research en Wageningen University hun krachten om bij te dragen aan de oplossing van belangrijke vragen in het domein van gezonde voeding en leefomgeving. Met ongeveer 30 vestigingen, 6.500 medewerkers en 10.000 studenten behoort Wageningen University \& Research wereldwijd tot de aansprekende kennisinstellingen binnen haar domein. De integrale benadering van de vraagstukken en de samenwerking tussen verschillende disciplines vormen het hart van de unieke Wageningen aanpak. 